$I 19.3$

$1181-F$

Minor Elements in Bedrock

Soil, and Vegetation

at an Outcrop of the

Phosphoria Formation on

Snowdrift Mountain

Southeastern Idaho

EOLOGICAL SURVEY BULLETIN 1181-F

\title{
metadc958032
}





\section{Minor Elements in Bedrock}

Soil, and Vegetation

at an Outcrop of the

Phosphoria Formation on

Snowdrift Mountain

\section{Southeastern Idaho}

By FREDERICK B. LOTSPEICH and ELLEN L. MARKWARD

CONTRIBUTIONS TO GENERAL GEOLOGY

GE OLOGICAL S U R V E Y B ULLE T I N $1181-\mathrm{F}$

A geochemical study

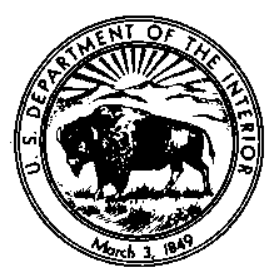


UNITED STATES DEPARTMENT OF THE INTERIOR

STEWART L. UDALL, Secretary

\section{GEOLOGIGAL SURVEY}

Thomas B. Nolan, Director 


\section{CONTENTS}

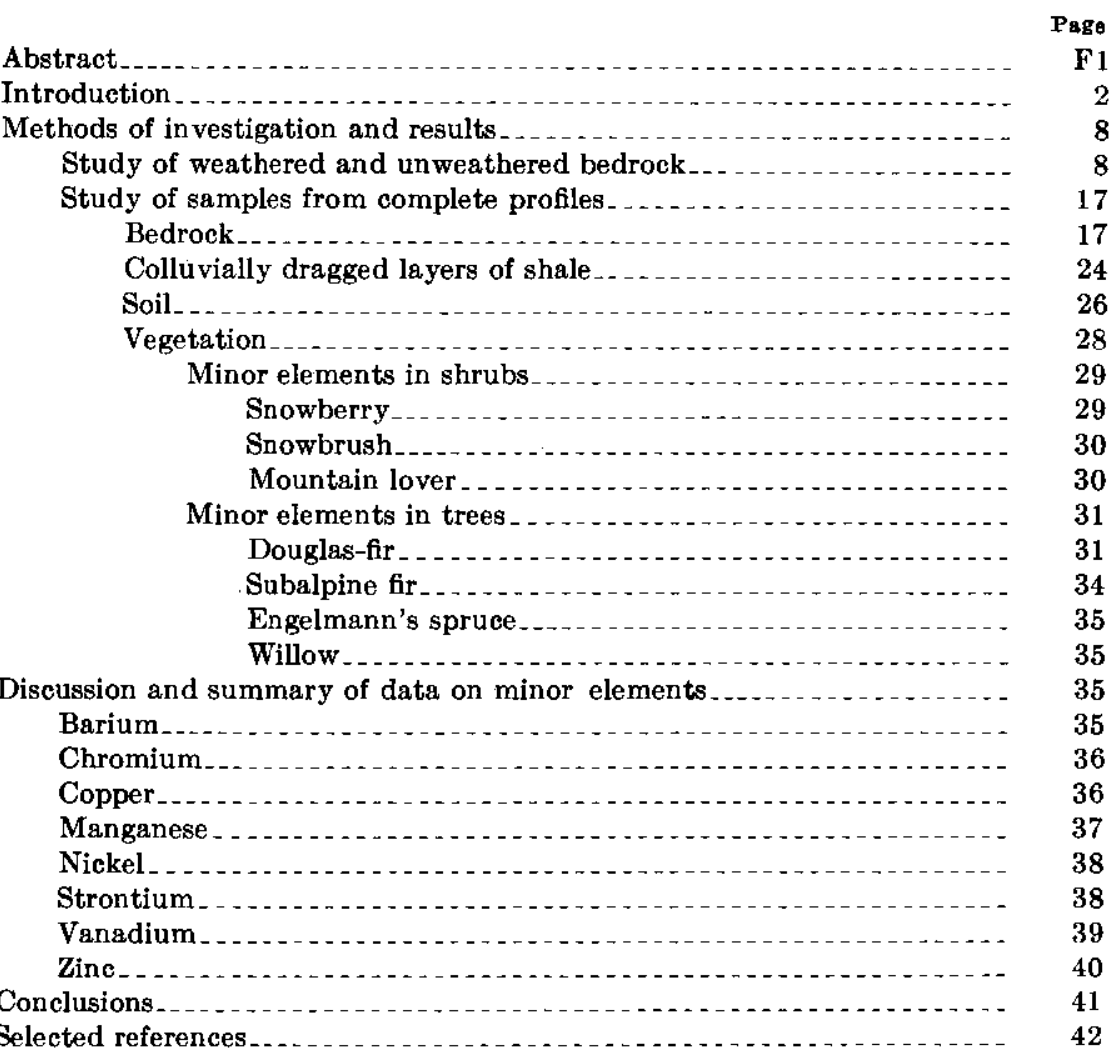

\section{ILLUSTRATIONS}

Plate 1. Comparison of chemical composition of fresh and weathered rock

Page

Figure 1. Index map........ F4

2. Photograph of side of trench 1 at sampling site

3. Diagrammatic longitudinal section showing groups of beds and sites of sampling . . .

4. Sketch map of area on west side of Snowdrift Mountain 


\section{TABLES}

TABLE 1. Soil profile description (generalized)

Page

2. Phosphorus and minor-element content of samples from the Meade Peak Phosphatic Shale Member of the Phosphoria Formation

3. Phosphorus and minor-element content of samples of 22 complete profiles and one bedrock exposure near Montpelier,

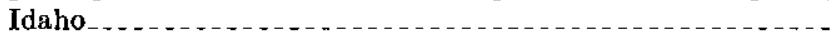

4. Summary of minor-element content of shrubs $\ldots \ldots$

5. Comparison of minor-lement composition of leaves (or needles) and twigs from four species of trees growing over the Phosphoria Formation and Park City Formation

6. Minor-element composition of Douglas-fir tree at site 21 


\title{
MINOR ELEMENTS IN BEDROGK, SOIL, AND VEGETATION AT AN OUTCROP OF THE PHOSPHORIA FORMATION ON SNOWDRIFT MOUNTAIN, SOUTHEASTERN IDAHO
}

\author{
By Frederick B. Lotspeich and Ellen L. Markwakd
}

\begin{abstract}
In southeastern Idaho, the Phosphoria Formation of Permian age contains measurable though minor amounts of barium, chromium, copper, manganese, nickel, strontium, vanadium, and zine. On the western slope of Snowdrift Mountain north of Montpelier, Idaho, this formation has been covered by a thin colluvium derived from the Grandeur Tongue of the Park City Formation (also of Permian age, although older), which is poorer in these metals. In this environment, conditions are favorable for studying the movement of the elements by analysis of samples of bedrock, soil, and vegetation.

In the unweathered rock, there seems to be a definite positive correlation of strontium content and a rough positive correlation of vanadium content with phosphorus content, irrespective of lithology. Zine shows a generally positive correlation with phosphorus in rock units in which silty constituents are high. An inverse correlation seems evident between manganese and phosphorus, and there seems to be a rough inverse correlation between barium and phosphorus.

In a comparison made between the metal content of samples of fresh phosphatic shale and that of weathered phosphatic shale in the twelve lithologic units studied, barium, chromium, and vanadium show an increase with weathering in 8,8 , and 10 units respectively ; zine shows a decrease with weathering in 9 units. For copper, manganese, nickel, phosphorus, and strontium, results are neither consistent nor conclusive; that is, a few units of fresh rock have the higher content of the metal measured, a few units of weatheres rock have the higher content, and in the remaining units differences are nil or negligible. In distribution, amount, and general relations with other elements, in all lithologic units except one, copper and nickel are similar.

Minor-element content of the source of the colluvium is about the same as that of most soil-forming material. The soil above the phosphatic shale contains more phosphorus, zinc, vanadium, chromium, and strontium, and slightly more copper, than that above the Grandeur Tongue of the Park City Formation. The barium content of soil over the two formations is about the same. Manganese, barium, nickel, and strontium are more concentrated in the upper soil horizons than in the lower.

Analysis of plants shows wide variations in metal content among different species of plants growing under similar conditions. Such variations are demon-
\end{abstract}


strated by analytical results on samples from three shrub species and are probably related to the rooting habit and physiology of each species. Different types of plant tissue also vary widely in minor-element content, as do the same types of tissue when of different ages.

\section{INTRODUCTION}

Although geochemical techniques for locating hidden ore deposits are currently in common use, further fundamental studies must be made before the full potentialities of geochemical methods of exploration can be utilized. Still important is the need, emphasized by Hawkes (1950), for fundamental research in the relative mobility of metallic elements in the zone of weathering.

This study is an attempt to relate, in accordance with Goldschmidt's enrichment principle (Goldschmidt, 1954), the metal content of bedrock to the metal content of an overlying colluvial soil of extraneous origin and to the metal content of vegetation growing in the soil. In addition, by comparing samples of weathered rock with samples of corresponding units of fresh rock and by studying the soil and the vertical distribution of elements between bedrock and surface, some information has been obtained on the behavior of several metallic elements during the weathering processes. Such information allows better interpretation of geochemical data and points the way to proper sampling.

The Phosphoria Formation, of Permian age, is well suited in southeastern Idaho to this type of investigation for the following reasons: the phosphatic shale beds of this formation contain several metals in measurable quantity; the shale beds are remarkably persistent and are nearly uniform in both lithology and chemical composition for tens of miles; in many places the outcrops have been covered by colluvium derived from another rock unit; and in some of these places, soil has developed from the colluvium, and a considerable plant cover is growing from the soil.

For the work reported here, samples were collected during the summers of 1954 and 1955 at a site about 20 miles north of Montpelier, Idaho (fig. 1). At this locality trenches had been dug in 1948 by the U.S. Geological Survey in its investigation of phosphate deposits of the northwestern United States, and underground workings had been started by the Central Farmers Fertilizer Co. about the same time. The site is at an altitude of approximately 8,300 feet. The mean annual temperature at Montpelier is $41.6^{\circ} \mathrm{F}$ (the range is from $-34^{\circ}$ to $102^{\circ}$ ), and the mean annual precipitation is about 22 inches. Although comparable data are not available for the work site, the mean annual temperature is thought to be about $3^{\circ} \mathrm{F}$ lower there because of the higher elevation. 
In the area studied, the Phosphoria Formation is made up of two members. The lower, the Meade Peak Phosphatic Shale Member, consists of about 180 feet of rock commonly called phosphatic shale, which may be subdivided into three types: the so-called phosphate rock, a highly phosphatic shale; argillaceous phosphate rock, which contains less phosphate and more silt and clay; and phosphatic mudstone, a hard well-indurated rock, some of which is nodular and some of which is highly calcareous. The upper member, the Rex Chert Member, is about 250 feet thick and consists of massive chert, siliceous shale, and, locally, lenses of calcareous mudstone. The Meade Peak is underlain by the Grandeur Tongue of the Park City Formation, a sequence of carbonate rocks and sandstone units more than 5,000 feet thick. The Rex is overlain by the Dinwoody Formation of Early Triassic age.

The Phosphoria beds studied lie in the western limb of the anticline that forms Snowdrift Mountain and are exposed locally on the western slope of the mountain. The beds strike N. $10^{\circ} \mathrm{E}$. and dip $70^{\circ} \mathrm{W}$. Because of the anticlinal structure, the older rocks (those of the Gran(leur Tongue of the Park City Formation) crop out on the mountain at an altitude higher than that of outcrops of the Meade Peak phosphatic shale member. Above the phosphatic shale beds of the Phosphoria Formation, the slope of the land surface is only $10^{\circ} \mathrm{W}$; ; but above the Park City Formation, it is about $25^{\circ} \mathrm{W}$. The topography has permitted movement of colluvium from the Park City Formation downward across the exposure of the phosphatic shales.

$\Delta t$ the work site, the sandy texture of the soil is a clue to the source of the colluvium. It is believed that the colluvium can not have been derived from the phosphatic shale, because the phosphatic shale beds contain very little sand (McKelvey, Davidson, O'Malley, and Smith, 1953). Furthermore, large chunks of limestone and dolomite in the colluvium resemble the carbonate rocks of the Park City Formation; no rocks of their type or appearance are associated with the phosphatic shale. This evidence, together with the position of the Park City exposure topographically higher than that of the Phosphoria Formation and with the presence of the steeper slope above the Park City, strongly suggests that through weathering and subsequent movement the colluvium has been derived from the Park City Formation. Frost action may have played an important role in the transport of this material; although the presence of incipient soil horizons rules out recent mixing action.

At the contact between the colluvium and the phoshatic shale, the truncated edges of the shale beds are overturned, having been rolled and dragged downslope by movement of the colluvium above them. 


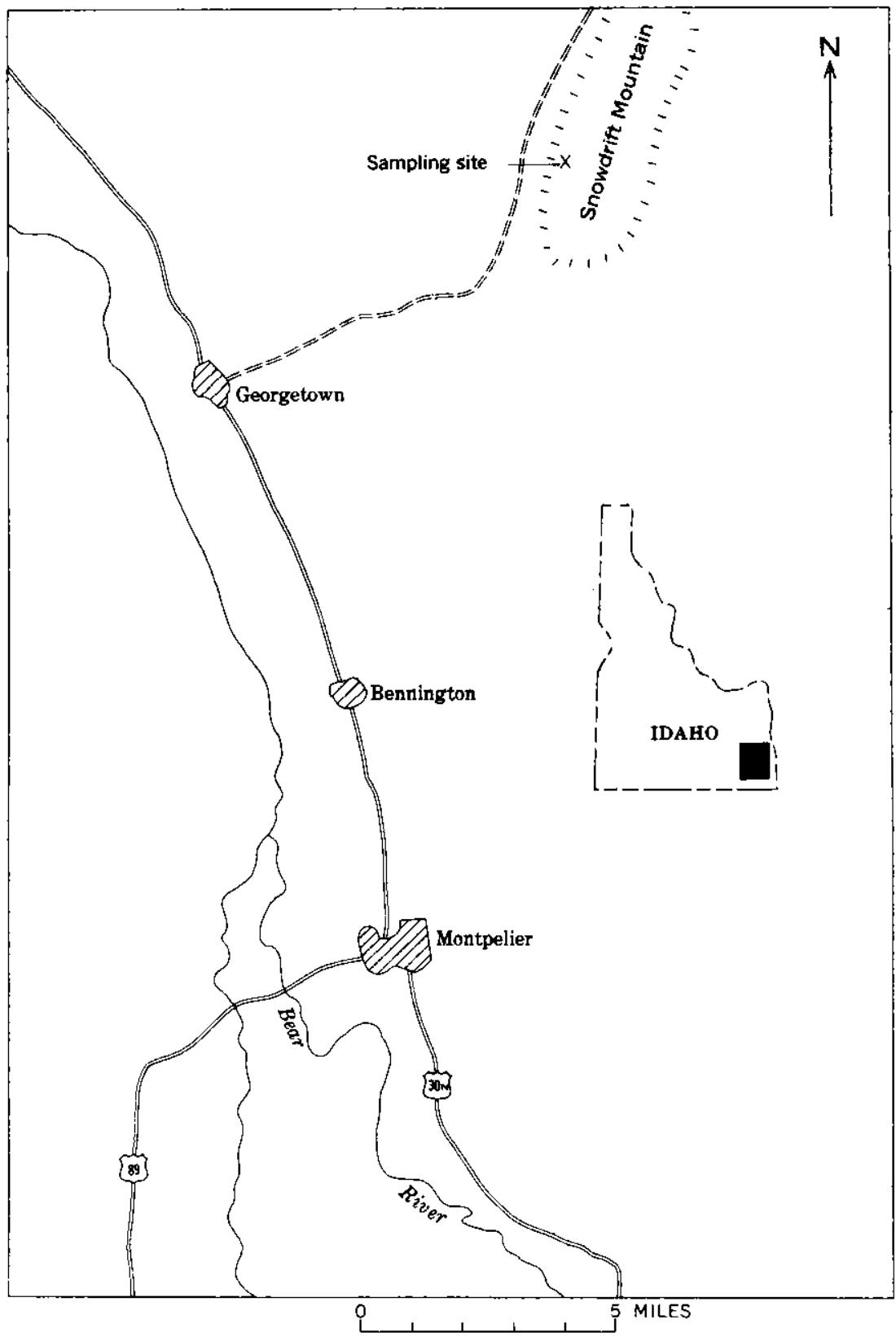

Frodre 1.--Index map showing location of sampling site on west side of Snowdrift Mountain, northeast of Georgetown, Idaho. 
Figure 2, a photograph, and figure 3, a diagrammatic section of the site where samples were collected, show the contact relation of the shale beds to the overlying colluvial soil. Although the dragged beds have been thinned and the attitude of their layering has been changed from a $70^{\circ}$ dip to one roughly parallel to the surface slope of $10^{\circ}$, the identity of some individual beds has been preserved to the extent that these beds are recognizable 40 feet or more downslope from their former position.

Soil horizons, though identifiable, are not well developed, as is indicated in the generalized soil-profile description (table 1). Among characteristics of the several soil horizons, the main variable is color, whose changes seem to be due to the degree to which the yellow of the parent material is masked by organic matter. The coloring effects of organic matter are especially noticeable in the horizons near the surface. Typical structures of the soil units are only incipiently developed, except for the weak granular structure in the upper horizons and the subangular blocks in the deeper horizons. The yellow material of the C horizon is somewhat vesicular and the vesicles have a darker color than that of the matrix.

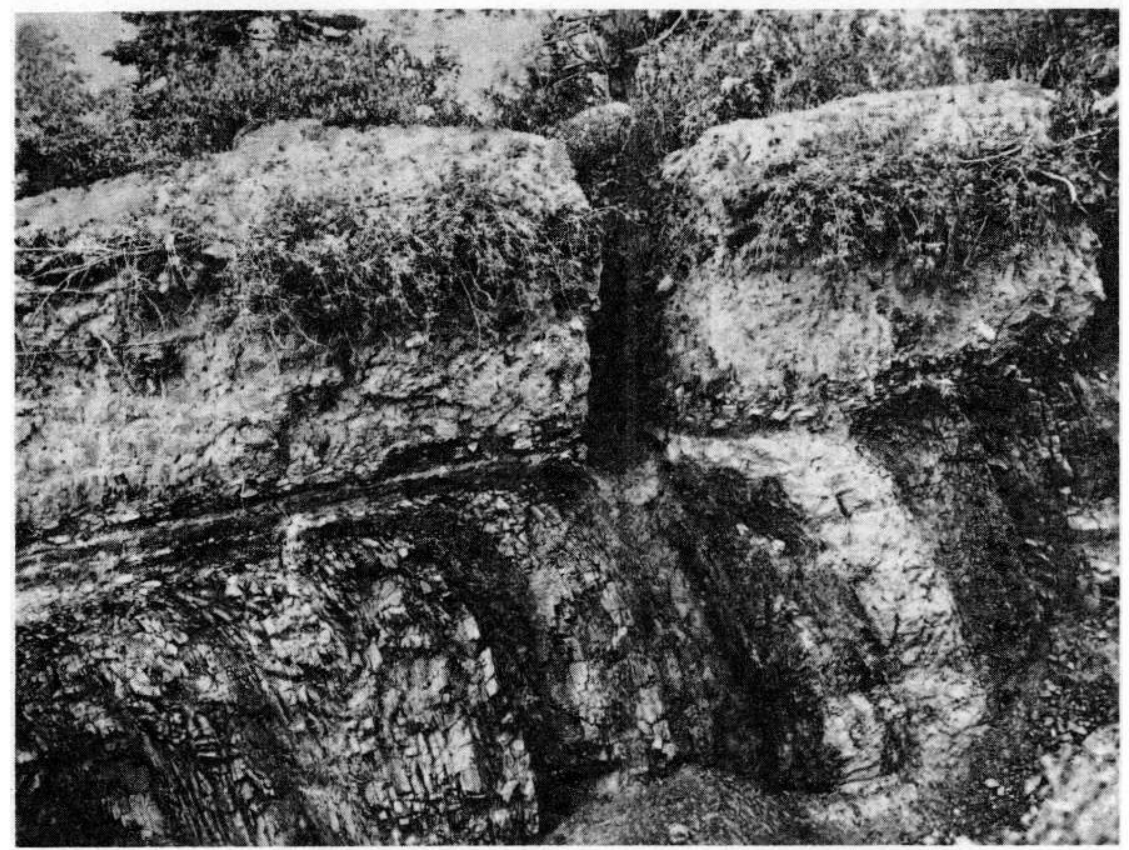

Figdre 2.-Photograph of side of trench 1 at sampling site near Georgetown in southeastern Idabo. Photograph shows truncated beds of phosphatic shale in Meade Peak Member of Phosphoria Formation which have been dragged by movement of overlying colluvium. Samples were taken from small excavation at center.

$695-901$ o $\quad 63 \quad-2$ 


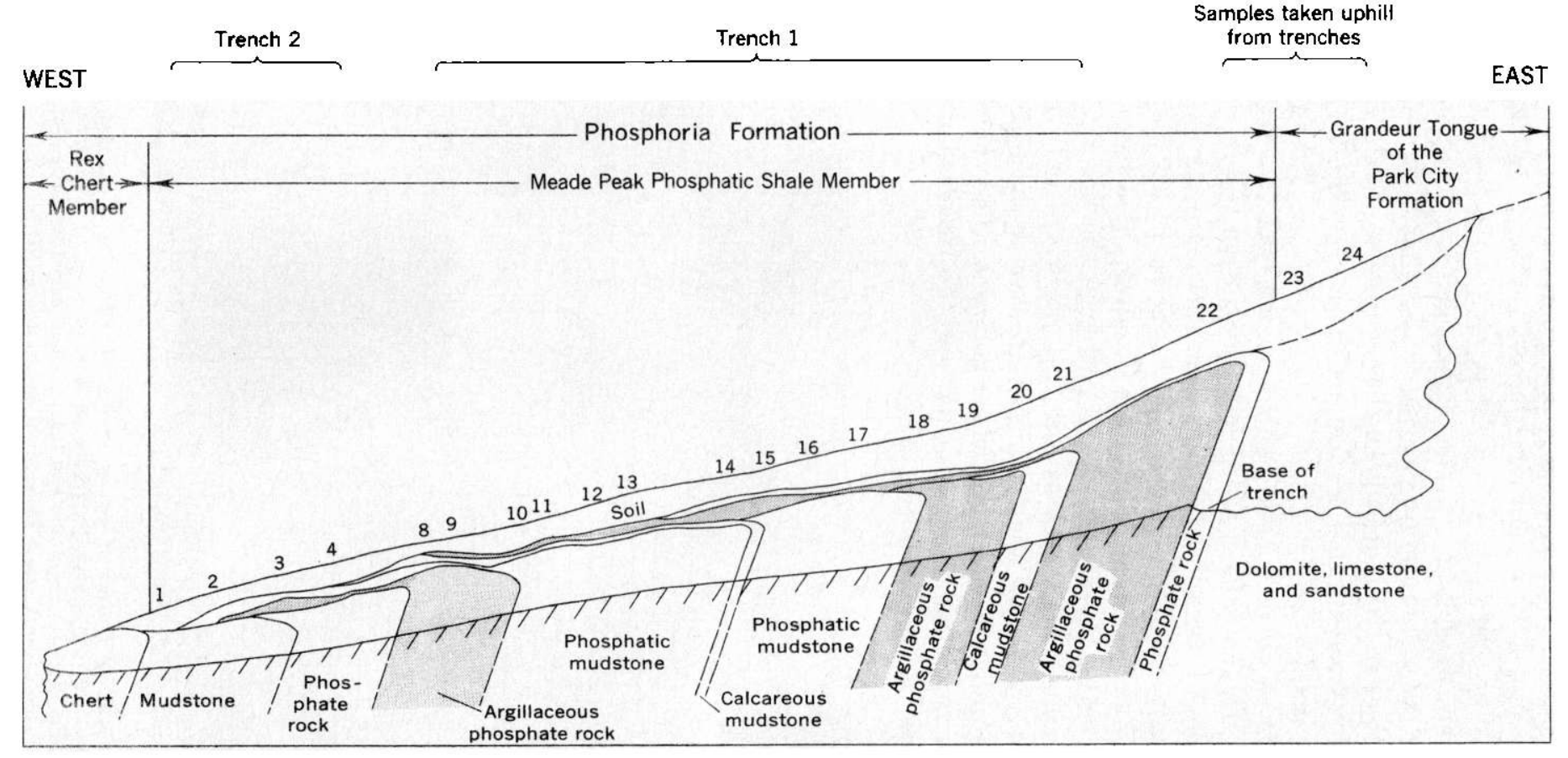
profle sampling near Georgetown, southeastern Idaho. Relative thieknes of soll is correct. 
TABLE 1.-Soil profle description (generalized)

[From the surfece as reference (designated 0 ), soil horlzons are measured both upward and downward. Soil colors are from "Soil Color Charts," published by Munsell Color Co., Inc., Baltimore, Md.]

\begin{tabular}{|c|c|c|}
\hline Forizon & $\begin{array}{c}\text { Depth } \\
\text { (inches) }\end{array}$ & Description \\
\hline 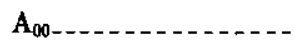 & $4-2$ & Dry leaves and other vegetal material, somewhat \\
\hline $\mathrm{A}_{0 \ldots} \ldots \ldots \ldots$ & $2-0$ & Partially decomposed plant material; leaves have \\
\hline Ground surface...-. & $\mathbf{0}$ & 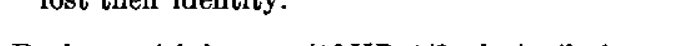 \\
\hline$A_{11-\ldots \ldots n} \ldots$ & $0-6$ & $\begin{array}{l}\text { Dark grayish-brown }(10 Y R \quad 4 / 2 \text {, dry }) \text { silt loam; } \\
\text { single-grained to weak crumb structure; many } \\
\text { roots; this is the horizon having maximum con- } \\
\text { tent of organic matter. }\end{array}$ \\
\hline$A_{12 \ldots \ldots} \ldots \ldots \ldots$ & $6-12$ & $\begin{array}{l}\text { Dark-brown (10YR } 4 / 3 \text {, dry) silt loam; single- } \\
\text { grained to weak crumb structure; roots are } \\
\text { numerous and organic matter content appears } \\
\text { to be high; separation of this horizon from } \mathrm{A}_{11} \\
\text { is arbitrary. }\end{array}$ \\
\hline $\mathrm{AC}_{-}$ & $12-16$ & $\begin{array}{l}\text { Yellowish-brown }(10 Y R 5 / 4 \text {, dry) silt loam; weak } \\
\text { blocky structure; roots are still - numerous, } \\
\text { although organic-matter content has decreased; } \\
\text { this is a transition horizon having arbitrary } \\
\text { boundaries above and below. }\end{array}$ \\
\hline C..- & $16-36$ & $\begin{array}{l}\text { Yellowish-brown ( } 10 Y R 5 / 6 \text {, dry) silt loam; sub- } \\
\text { angular blocks; number of roots decreases with } \\
\text { depth; this horizon may contain numerous } \\
\text { limestone, sandstone, and dolomite boulders, } \\
\text { ranging in size from } 6 \text { to } 24 \text { inches in greatest } \\
\text { dimension, that have a weathered skin; sharp } \\
\text { boundary with underlying, colluvially dragged } \\
\text { layers of phosphatic shale. }\end{array}$ \\
\hline
\end{tabular}

In southeastern Idaho, the mountain slopes support forest growth, including both trees and shrubs; the broad valleys support only brushy plant cover. The tree species most abundant in the general region is quaking aspen (Populus tremuloides); Douglas-fir (Pseudotsuga taxifolia) and lodgepole pine (Pinus contorta var. latifolia) are next in abundance. At altitudes above 8,000 feet, Engelmann's spruce (Picea engelmanni), subalpine fir (Abies lasiocarpa), and limber pine (Pinus flexilis) are common members of the forest community. The most numerous of the shrubby species that cover the lower slopes are mountain mahogany (Cercocarpus sp.), snowbrush (Ceanothus velutinus), snowberry (Symphoricarpos oreophilus), and mountain lover (Pachistima myrsinites). Sagebrush (Artemisia tridentata), which is plentiful in certain areas, in some places extends to an altitude of 9,000 feet although it is usually restricted to the valley bottoms. In the immediate vicinity of the outcrop studied at East Georgetown, the trees in the order of their abundance are Douglas-fir, spruce, subalpine fir, aspen, and willow, and the chief shrubs are snowbrush, snowberry, and mountain lover. 
In this report, the senior author is responsible for planning the investigation, for the field work, for some of the analyses, and for the major part of interpretation of analytical results. The contribution of the junior author lies in the organization and presentation of material and in the checking of data.

Special thanks are due the Central Farmers Fertilizer Co. of Chicago for permitting collection of samples from their property and for the trenching they did for the benefit of the Geological Survey field party.

\section{METHODS OF INVESTIGATION AND RESULTS}

For study of the behavior of several chemical elements during the weathering process and of the movement of these elements from their source in the bedrock to their present position, data were obtajned from analytical determinations made on different types of material during two phases of investigation. In one phase, a comparative study was made of samples of weathered bedrock and samples of fresh bedrock. In the second phase, to supply information on what happens in the vertical zone between bedrock and surface, complete profile sampling was done-that is, samples were taken from bedrock in place, from shale layers that had been dragged by moving colluvium, from soil developed in the colluvium, and from plants growing in the soil.

The surface and near-surface samples came from the trenches shown in figures 2 and 3 , and in figure 4, a diagrammatic sketch of the area in plan. Trench 1 , referred to here as the main trench, had been scooped out with a bulldozer in 1948. For purposes of the present work, this main trench was cleaned out and then deepened along its full length by an additional excavation 2 feet wide and $11 / 2$ feet deep; exposures were therefore available of soil, colluvially dragged layers, and phosphatic shales in place to depths of 8 to 20 feet. Trench 2, a smaller trench, was dug about 100 feet north of the main trench, as part of the work reported here, in order to provide fresh exposures of the soil and vegetation, which had been stripped away along the top of trench 1. Figure 3, the diagrammatic logitudinal section, is a composite of both trenches.

\section{STUDY OF WEATHERED AND UNWEATHERED BEDROCK}

The trenches furnished samples of the phosphatic shale beds in the weathering zone; a channel sample weighing between 8 and 12 pounds was taken from each lithologic unit studied. Samples of the same units at depth were taken from the Central Farmers Fertilizer Co. 
mine about 800 feet down dip from rock exposed in the treneh. Beds that are noticeably weathered near the surface appear unweathered in the mine.

Phosphorus is the only major rock-forming constituent of the phosphatic shales chemically determined in this study; the phosphorus content was estimated by means of a semiquantitative wet chemical colorimetric method, which, on the basis of the reactions described by Snell and Snell (1949, p. 672), had been developed in the laboratories of the U.S. Geological Survey for field use. The zinc content of the shale samples was also determined by use of a wet chemical semiquantitative field method. The shale samples were also analyzed by semiquantitative spectrographic methods for copper, nickel, manganese, vanadium, chromium, barium, and strontium; these analyses were made in a truck-mounted spectrograph. Analyses of individual samples are reported in table 2, and averages of groups of analyses representing the respective rock units are diagrammatically presented on plate 1 .

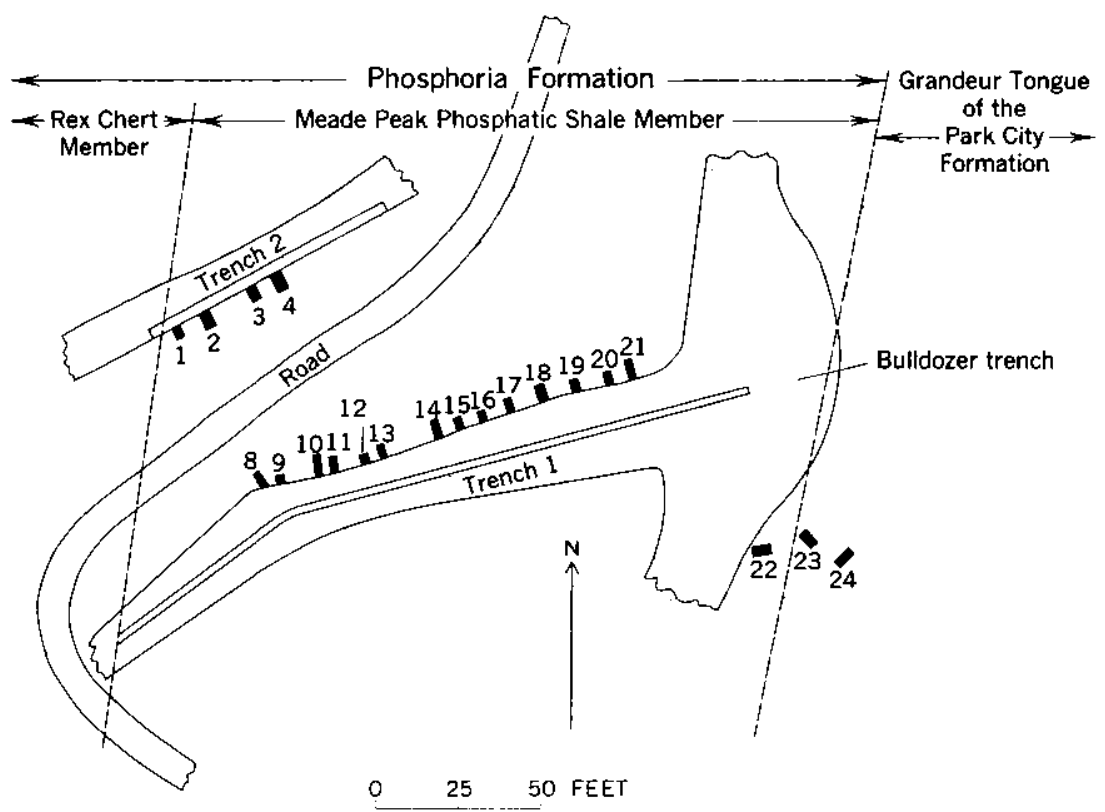

Figure 4.-Diagrammatic sketch map of area on west side of Snowdrift Mountaln, northeast of Georgetown, Idabo. Trenches are outlined. Sites of complete profle sampling are numbered. 
TABLE 2.-Phosphorus and minor-element content of samples from the Meade Peak Phosphatic Shale Member of the Phosphoria Formation

[Phosphorus is expressed in percent, trace elements in parts per million. Zinc and phosphorus were determined, by semlquantitative fleld methods, by $R$. R. Beins and $G$. C. Campbell; other elements, by semiquantitative spectrographle methods, by U. Oda]

\begin{tabular}{l|l|l|l|l|l|l|l|l|l|l}
\hline \multicolumn{1}{c|}{ 8ample } & \multicolumn{10}{c}{ Constituents } \\
\hline Lab. No. & Field No. & $P$ & $\mathrm{Zn}$ & $\mathrm{Cu}$ & $\mathrm{Ni}$ & $\mathrm{Mn}$ & $\mathrm{V}$ & $\mathrm{Cr}$ & $\mathrm{Ba}$ & $\mathrm{Sr}$ \\
\hline
\end{tabular}

SAMPLES OF UNWEATHERED ROCK, FROM MINE

Phosphate rock

\begin{tabular}{|c|c|c|c|c|c|c|c|c|c|c|}
\hline $\begin{array}{r}54-5751 \ldots \\
5752 \ldots \\
5753 \ldots \\
5754 \ldots \\
5755 \ldots \\
5756 \ldots \\
5757 \ldots \\
5758 \ldots \\
5759 \ldots \\
5760 \ldots \\
5761 \ldots \\
5762 \ldots\end{array}$ & $\begin{array}{l}657 \\
658 \\
659 \\
660 \\
661 \\
662 \\
663 \\
664 \\
665 \\
666 \\
667 \\
668\end{array}$ & $\begin{array}{r}7.50 \\
10.00 \\
1.50 \\
7.50 \\
2.00 \\
7.50 \\
7.50 \\
15.00 \\
4.25 \\
1.00 \\
15.00 \\
7.50\end{array}$ & $\begin{array}{r}400 \\
1,000 \\
200 \\
1,000 \\
1,000 \\
1,750 \\
1,000 \\
1,000 \\
3,500 \\
300 \\
1,500 \\
2,000\end{array}$ & $\begin{array}{r}15 \\
\mathbf{3 5} \\
\mathbf{3 5} \\
\mathbf{3 5} \\
\mathbf{7 5} \\
100 \\
\mathbf{3 5} \\
\mathbf{3 5} \\
100 \\
\mathbf{1 5} \\
75 \\
75\end{array}$ & $\begin{array}{r}75 \\
75 \\
20 \\
10 \\
75 \\
150 \\
75 \\
75 \\
150 \\
<5 \\
75 \\
100\end{array}$ & $\begin{array}{l}200 \\
150 \\
500 \\
350 \\
350 \\
200 \\
200 \\
100 \\
200 \\
100 \\
75 \\
100\end{array}$ & $\begin{array}{r}750 \\
1,500 \\
350 \\
500 \\
750 \\
1,500 \\
1,500 \\
2,000 \\
1,500 \\
750 \\
1,500 \\
2,000\end{array}$ & $\begin{array}{r}\mathbf{7 5 0} \\
\mathbf{7 5 0} \\
\mathbf{3 5 0} \\
\mathbf{5 0 0} \\
\mathbf{7 5 0} \\
1,500 \\
\mathbf{7 5 0} \\
1,000 \\
1, \mathbf{5 0 0} \\
\mathbf{1 5 0} \\
750 \\
750\end{array}$ & $\begin{array}{r}75 \\
75 \\
100 \\
75 \\
150 \\
150 \\
100 \\
75 \\
100 \\
<10 \\
50 \\
50\end{array}$ & $\begin{array}{r}3,500 \\
3,500 \\
350 \\
1,000 \\
750 \\
3,500 \\
2,000 \\
3,500 \\
2,000 \\
750 \\
3,500 \\
3,500\end{array}$ \\
\hline
\end{tabular}

Argillaceons phosphate rock

\begin{tabular}{|c|c|c|c|c|c|c|c|c|c|c|}
\hline $\begin{array}{r}\mathbf{5 4 - 5 7 6 3} \\
\mathbf{5 7 6 4} \\
\mathbf{5 7 6 5} \\
\mathbf{5 7 6 6} \\
\mathbf{5 7 6 7} \\
\mathbf{5 7 6 8} \\
\mathbf{5 7 6 9} \\
\mathbf{5 7 7 0} \\
\mathbf{5 7 7 1} \\
\mathbf{5 7}\end{array}$ & $\begin{array}{l}669 \\
670 \\
671 \\
672 \\
673 \\
674 \\
675 \\
676 \\
677\end{array}$ & $\begin{array}{l}0.75 \\
7.50 \\
7.50 \\
5.00 \\
4.25 \\
3.75 \\
1.50 \\
.50 \\
4.25\end{array}$ & $\begin{array}{r}500 \\
7,000 \\
3,500 \\
3,500 \\
2,000 \\
3,000 \\
750 \\
300 \\
2,000\end{array}$ & $\begin{array}{r}15 \\
100 \\
100 \\
150 \\
75 \\
100 \\
35 \\
15 \\
150\end{array}$ & $\begin{array}{r}<5 \\
350 \\
350 \\
200 \\
150 \\
150 \\
35 \\
20 \\
200\end{array}$ & $\begin{array}{r}150 \\
100 \\
75 \\
100 \\
75 \\
100 \\
150 \\
150 \\
100\end{array}$ & $\begin{array}{r}500 \\
5,000 \\
3,500 \\
3,500 \\
1,500 \\
2,000 \\
200 \\
50 \\
500\end{array}$ & $\begin{array}{r}150 \\
1,500 \\
1,500 \\
2,000 \\
1,500 \\
2,000 \\
350 \\
200 \\
1,500\end{array}$ & $\begin{array}{r}<10 \\
100 \\
100 \\
150 \\
100 \\
150 \\
75 \\
75 \\
200\end{array}$ & $\begin{array}{r}500 \\
1,500 \\
2,000 \\
2,000 \\
2,000 \\
2,000 \\
500 \\
350 \\
750\end{array}$ \\
\hline
\end{tabular}

Phosphatic mudstone

\begin{tabular}{|c|c|c|c|c|c|c|c|c|c|c|}
\hline $\begin{array}{r}\text { 55-3923 } \ldots \\
3924 \ldots \\
3925 \ldots \\
3926 \ldots \\
3927 \ldots \\
3928 \ldots \\
\end{array}$ & $\begin{array}{l}\mathbf{7 3 6} \\
\mathbf{7 3 7} \\
\mathbf{7 3 8} \\
\mathbf{7 3 8} \\
\mathbf{7 4 0} \\
\mathbf{7 4 1}\end{array}$ & $\begin{array}{l}5.0 \\
5.0 \\
4.0 \\
1.0 \\
2.5 \\
2.5\end{array}$ & $\begin{array}{r}400 \\
600 \\
400 \\
200 \\
1,500 \\
1,500\end{array}$ & $\begin{array}{r}100 \\
75 \\
75 \\
50 \\
150 \\
100\end{array}$ & $\begin{array}{r}75 \\
100 \\
50 \\
20 \\
200 \\
150\end{array}$ & $\begin{array}{l}200 \\
200 \\
200 \\
200 \\
200 \\
200\end{array}$ & $\begin{array}{l}200 \\
200 \\
200 \\
200 \\
350 \\
350\end{array}$ & $\begin{array}{r}500 \\
750 \\
500 \\
350 \\
1,500 \\
1,000\end{array}$ & $\begin{array}{r}150 \\
150 \\
150 \\
75 \\
150 \\
200\end{array}$ & $\begin{array}{l}750 \\
750 \\
500 \\
350 \\
500 \\
350\end{array}$ \\
\hline
\end{tabular}

Nodular phosphatic madstone

\begin{tabular}{|c|c|c|c|c|c|c|c|c|c|c|}
\hline $\begin{array}{r}55-3929 \ldots \\
3930 \ldots \\
3931 \ldots \\
3932 \ldots \\
3933 \ldots \\
3934 \ldots \\
3935 \ldots \\
3936 \ldots \\
3937 \ldots \\
3938 \ldots\end{array}$ & $\begin{array}{l}742 \\
743 \\
744 \\
745 \\
746 \\
747 \\
748 \\
749 \\
750 \\
751\end{array}$ & $\begin{array}{l}1.0 \\
2.0 \\
1.0 \\
1.0 \\
1.5 \\
1.5 \\
1.0 \\
1.0 \\
2.5 \\
3.0\end{array}$ & $\begin{array}{r}600 \\
600 \\
400 \\
1,500 \\
1,000 \\
1,500 \\
600 \\
300 \\
700 \\
2,000\end{array}$ & $\begin{array}{r}50 \\
75 \\
75 \\
100 \\
75 \\
75 \\
75 \\
75 \\
150 \\
150\end{array}$ & $\begin{array}{r}50 \\
75 \\
75 \\
100 \\
100 \\
100 \\
75 \\
50 \\
200 \\
350\end{array}$ & $\begin{array}{l}150 \\
150 \\
200 \\
200 \\
200 \\
200 \\
200 \\
350 \\
150 \\
100\end{array}$ & $\begin{array}{l}\mathbf{3 5 0} \\
\mathbf{5 0 0} \\
\mathbf{7 5 0} \\
\mathbf{7 5 0} \\
\mathbf{5 0 0} \\
\mathbf{7 5 0} \\
\mathbf{5 0 0} \\
\mathbf{3 5 0} \\
\mathbf{5 0 0} \\
\mathbf{5 0 0}\end{array}$ & $\begin{array}{r}750 \\
750 \\
750 \\
1,500 \\
1,000 \\
1,500 \\
750 \\
350 \\
1,500 \\
1,500\end{array}$ & $\begin{array}{l}150 \\
350 \\
350 \\
350 \\
200 \\
350 \\
200 \\
200 \\
500 \\
200\end{array}$ & $\begin{array}{l}500 \\
750 \\
500 \\
500 \\
500 \\
500 \\
500 \\
350 \\
500 \\
500\end{array}$ \\
\hline
\end{tabular}

Calcareons madstone

\begin{tabular}{|c|c|c|c|c|c|c|c|c|c|c|}
\hline $55-3939$ & 752 & 10.0 & 1,000 & 75 & 200 & 50 & 1,000 & 1,500 & 100 & 3,500 \\
\hline
\end{tabular}


TABLE 2.-Phosphorus and minor-element contenl of samples from the Meade Peak Phosphatic Shale Member of the Phosphoria Formation-Con'tinued

\begin{tabular}{l|l|l|l|l|l|l|l|l|l|l}
\hline \multicolumn{1}{c|}{ Sample } & \multicolumn{10}{c}{ Constituents } \\
\hline Lab. No. Fleld No. & P & Zn & Cu & N1 & Mn & V & Cr & Ba & St \\
\hline
\end{tabular}

SAMPLES OF UNWEATHERED ROCK, FROM MINE-Continued

Nodalar phosphatic madstone

\begin{tabular}{|c|c|c|c|c|c|c|c|c|c|c|}
\hline $\begin{array}{r}55-3940 \ldots \\
3941 \ldots \\
3942 \ldots \\
3943 \ldots \\
3944 \ldots \\
3945 \ldots \\
3946 \ldots \\
3947 \\
3948- \\
3949 \\
3950 \ldots \\
3951 \ldots \\
3952 \ldots\end{array}$ & $\begin{array}{l}753 \\
754 \\
755 \\
756(\mathrm{a}) \\
756(\mathrm{~b}) \\
757 \\
758 \\
759 \\
760 \\
761 \\
762 \\
763 \\
764\end{array}$ & $\begin{array}{r}1.0 \\
3.0 \\
.5 \\
.1 \\
1.5 \\
6.0 \\
12.5 \\
10.0 \\
5.0 \\
7.5 \\
3.0 \\
6.0 \\
2.0\end{array}$ & $\begin{array}{r}200 \\
100 \\
50 \\
20 \\
70 \\
300 \\
300 \\
300 \\
300 \\
1,500 \\
700 \\
3,000 \\
600\end{array}$ & $\begin{array}{r}\mathbf{3 5} \\
20 \\
15 \\
15 \\
\mathbf{3 5} \\
\mathbf{3 5} \\
\mathbf{3 5} \\
\mathbf{3 5} \\
\mathbf{5 0} \\
100 \\
100 \\
150 \\
\mathbf{7 5}\end{array}$ & $\begin{array}{r}50 \\
35 \\
10 \\
5 \\
20 \\
75 \\
35 \\
35 \\
50 \\
150 \\
150 \\
350 \\
50\end{array}$ & $\begin{array}{r}350 \\
200 \\
200 \\
200 \\
200 \\
100 \\
100 \\
75 \\
150 \\
100 \\
200 \\
100 \\
100\end{array}$ & $\begin{array}{r}500 \\
150 \\
100 \\
100 \\
200 \\
350 \\
500 \\
200 \\
350 \\
350 \\
350 \\
1,000 \\
350\end{array}$ & $\begin{array}{r}200 \\
150 \\
100 \\
75 \\
150 \\
500 \\
1,500 \\
350 \\
500 \\
1,500 \\
1,000 \\
2,000 \\
500\end{array}$ & $\begin{array}{r}100 \\
150 \\
50 \\
50 \\
100 \\
200 \\
75 \\
100 \\
150 \\
100 \\
150 \\
200 \\
150\end{array}$ & $\begin{array}{r}200 \\
500 \\
200 \\
350 \\
350 \\
750 \\
3,500 \\
2,000 \\
750 \\
750 \\
500 \\
1,000 \\
\mathbf{3 5 0}\end{array}$ \\
\hline
\end{tabular}

Phosphatic madstone

\begin{tabular}{|c|c|c|c|c|c|c|c|c|c|c|}
\hline $\begin{array}{r}55-3953--- \\
3954-- \\
3955 \\
3956-- \\
3957- \\
3958- \\
3959- \\
3960- \\
3961=- \\
3962 \ldots\end{array}$ & $\begin{array}{l}\mathbf{7 6 5} \\
\mathbf{7 6 6} \\
\mathbf{7 6 i 7} \\
768 \\
769 \\
\mathbf{7 7 0} \\
\mathbf{7 7 1} \\
\mathbf{7 7 2} \\
\mathbf{7 7 3} \\
\mathbf{7 7 4}\end{array}$ & $\begin{array}{l}4.0 \\
3.0 \\
2.5 \\
3.0 \\
2.5 \\
.1 \\
1.0 \\
.1 \\
1.0 \\
2.5\end{array}$ & $\begin{array}{r}2,000 \\
1,000 \\
1,000 \\
1,500 \\
1,500 \\
100 \\
200 \\
70 \\
1,500 \\
1,000\end{array}$ & $\begin{array}{r}150 \\
75 \\
150 \\
100 \\
75 \\
10 \\
15 \\
15 \\
75 \\
75\end{array}$ & $\begin{array}{r}350 \\
150 \\
200 \\
150 \\
150 \\
<5 \\
10 \\
5 \\
150 \\
100\end{array}$ & $\begin{array}{r}100 \\
75 \\
100 \\
75 \\
100 \\
75 \\
100 \\
150 \\
150 \\
200\end{array}$ & $\begin{array}{r}750 \\
500 \\
500 \\
350 \\
350 \\
35 \\
75 \\
75 \\
500 \\
350\end{array}$ & $\begin{array}{r}2,000 \\
1,500 \\
1,500 \\
2,000 \\
2,000 \\
150 \\
200 \\
150 \\
1,500 \\
1,000\end{array}$ & $\begin{array}{r}75 \\
150 \\
200 \\
100 \\
200 \\
<5 \\
50 \\
5 \\
350 \\
350\end{array}$ & $\begin{array}{r}500 \\
750 \\
750 \\
750 \\
1,000 \\
350 \\
350 \\
350 \\
500 \\
750\end{array}$ \\
\hline
\end{tabular}

Argillaceous phosphate rock

\begin{tabular}{|c|c|c|c|c|c|c|c|c|c|c|}
\hline $\begin{array}{r}\text { 55-3963.- } \\
3964=- \\
3965\end{array}$ & $\begin{array}{l}775 \\
776 \\
777\end{array}$ & $\begin{array}{l}0.5 \\
1.5 \\
1.0\end{array}$ & $\begin{array}{l}200 \\
400 \\
400\end{array}$ & $\begin{array}{l}20 \\
35 \\
35\end{array}$ & $\begin{array}{l}20 \\
35 \\
35\end{array}$ & $\begin{array}{l}150 \\
150 \\
150\end{array}$ & $\begin{array}{l}200 \\
200 \\
200\end{array}$ & $\begin{array}{l}350 \\
750 \\
500\end{array}$ & $\begin{array}{l}200 \\
350 \\
150\end{array}$ & $\begin{array}{l}500 \\
750 \\
500\end{array}$ \\
\hline
\end{tabular}

Argillaceous phosphate rock

\begin{tabular}{rr|r|r|r|r|r|r|r|r|r}
\hline $55-3966$ & 778 & 5.0 & 1,000 & 100 & 100 & 150 & 200 & 2,000 & 350 & 750 \\
$3967--$ & 779 & 2.0 & 400 & 50 & 35 & 150 & 100 & 500 & 200 & 750 \\
$3968--$ & 780 & 4.0 & 1,500 & 50 & 75 & 100 & 200 & 1,500 & 200 & 1,000 \\
$3969--$ & 781 & 5.0 & 600 & 35 & 75 & 100 & 350 & 1,000 & 100 & 1,000 \\
\hline
\end{tabular}

Calcareous mudstone

\begin{tabular}{r|r|r|r|r|r|r|r|r|r}
\hline $55-3970--$ & 782 & 2.0 & 400 & 50 & 20 & 200 & 200 & 500 & 150 \\
$3971-$ & 783 & 2.5 & 1,500 & 75 & 100 & 150 & 200 & 1,500 & 200 \\
$3972--$ & 784 & 3.0 & 1,500 & 75 & 150 & 50 & 350 & 1,000 & 100 \\
$54-5772 .-$ & 678 & 2.00 & 1,500 & 75 & 150 & 150 & 200 & 1,000 & 200 \\
\hline
\end{tabular}


TABLE 2.-Phosphorus and minor-element content of samples from the Meade Peak Phosphatic Shale Member of the Phosphoria Formation-Continued

\begin{tabular}{l|l|l|l|l|l|l|l|l|l|l|l}
\hline \multicolumn{1}{c|}{ Sample } & \multicolumn{10}{c}{ Constituents } \\
\hline Lab. No. Field No. & $\mathrm{P}$ & $\mathrm{Zn}$ & $\mathrm{Cu}$ & $\mathrm{Ni}$ & $\mathrm{Mn}$ & $\mathrm{V}$ & $\mathrm{Cr}$ & $\mathrm{Ba}$ & $\mathrm{Sr}$ \\
\hline
\end{tabular}

SAMPLES OF UNWEATHERED ROCK, FROM MINE-Continued

Argillaceous phosphate rock

\begin{tabular}{|c|c|c|c|c|c|c|c|c|c|c|}
\hline 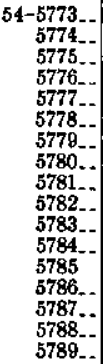 & $\begin{array}{l}680 \\
681 \\
682 \\
683 \\
684 \\
685 \\
686 \\
687 \\
688 \\
689 \\
690 \\
691 \\
692 \\
693 \\
694 \\
695 \\
697\end{array}$ & $\begin{array}{l}2.00 \\
0.75 \\
3.75 \\
2.50 \\
7.50 \\
5.00 \\
7.50 \\
7.50 \\
1.50 \\
5.00 \\
7.50 \\
7.50 \\
7.50 \\
3.75 \\
2.00 \\
0.15 \\
3.75\end{array}$ & $\begin{array}{r}1,000 \\
300 \\
750 \\
1,250 \\
750 \\
5,000 \\
3,000 \\
2,500 \\
2,500 \\
1,500 \\
2,500 \\
3,500 \\
2,500 \\
1,500 \\
1,250 \\
750 \\
1,500\end{array}$ & $\begin{array}{r}20 \\
15 \\
100 \\
75 \\
75 \\
75 \\
100 \\
100 \\
15 \\
150 \\
75 \\
100 \\
100 \\
75 \\
20 \\
<1 \\
75\end{array}$ & $\begin{array}{r}20 \\
10 \\
100 \\
75 \\
75 \\
150 \\
150 \\
100 \\
35 \\
150 \\
150 \\
150 \\
150 \\
150 \\
75 \\
<5 \\
150\end{array}$ & $\begin{array}{r}75 \\
100 \\
100 \\
100 \\
50 \\
75 \\
75 \\
75 \\
100 \\
75 \\
50 \\
50 \\
35 \\
50 \\
75 \\
75 \\
75\end{array}$ & $\begin{array}{r}350 \\
200 \\
350 \\
350 \\
500 \\
3,500 \\
3,500 \\
3,500 \\
1,000 \\
2,000 \\
2,000 \\
2,000 \\
2,000 \\
1,500 \\
350 \\
100 \\
750\end{array}$ & $\begin{array}{l}350 \\
150 \\
750 \\
500 \\
750 \\
750 \\
750 \\
750 \\
350 \\
750 \\
750 \\
750 \\
750 \\
750 \\
500 \\
50 \\
750\end{array}$ & $\begin{array}{r}35 \\
10 \\
150 \\
150 \\
75 \\
75 \\
150 \\
150 \\
75 \\
150 \\
150 \\
100 \\
100 \\
150 \\
75 \\
<10 \\
100\end{array}$ & $\begin{array}{r}500 \\
200 \\
760 \\
350 \\
1,000 \\
1,000 \\
1,000 \\
1,000 \\
350 \\
1,000 \\
1,000 \\
750 \\
750 \\
750 \\
350 \\
100 \\
750\end{array}$ \\
\hline
\end{tabular}

Phosphate rock

\begin{tabular}{|c|c|c|c|c|c|c|c|c|c|c|}
\hline $\begin{array}{r}54-5790 \ldots \\
5791 \ldots \\
5792 \ldots \\
5793\end{array}$ & $\begin{array}{l}698 \\
699 \\
700 \\
701\end{array}$ & $\begin{array}{r}10.00 \\
7.50 \\
15.00 \\
7.50\end{array}$ & $\begin{array}{l}1,500 \\
1,500 \\
2,000 \\
2,500\end{array}$ & $\begin{array}{r}75 \\
150 \\
100 \\
75\end{array}$ & $\begin{array}{r}50 \\
100 \\
75 \\
75\end{array}$ & $\begin{array}{l}10 \\
20 \\
15 \\
15\end{array}$ & $\begin{array}{l}3,500 \\
3,500 \\
5,000 \\
3,500\end{array}$ & $\begin{array}{l}500 \\
750 \\
750 \\
750\end{array}$ & $\begin{array}{l}75 \\
75 \\
75 \\
75\end{array}$ & $\begin{array}{l}2,000 \\
1,500 \\
2,000 \\
1,500\end{array}$ \\
\hline
\end{tabular}

SAMPLES OF WEATHERED ROCK, FROM TRENCH

Phosphate rock

\begin{tabular}{|c|c|c|c|c|c|c|c|c|c|c|}
\hline $\begin{array}{r}54-5639 \ldots \\
5640 \ldots \\
5641 \\
5642 \ldots \\
5643 \ldots \\
5644 \ldots \\
5645 \ldots \\
5646 \ldots \\
5647 \ldots \\
5648 \ldots \\
5649 \ldots \\
5650 \ldots \\
5651 \\
5652 \\
5\end{array}$ & $\begin{array}{l}158 \\
159 \\
160 \\
161 \\
162 \\
163 \\
164 \\
165 \\
166 \\
167 \\
168 \\
169 \\
170 \\
171\end{array}$ & $\begin{array}{r}6.00 \\
1.50 \\
15.00 \\
3.00 \\
7.50 \\
4.25 \\
10.00 \\
7.50 \\
7.50 \\
15.00 \\
7.50 \\
7.50 \\
5.00 \\
2.50\end{array}$ & $\begin{array}{r}700 \\
2,500 \\
500 \\
2,500 \\
1,000 \\
2,500 \\
750 \\
1,500 \\
750 \\
750 \\
1,000 \\
2,500 \\
2,500 \\
750\end{array}$ & $\begin{array}{l}15 \\
15 \\
15 \\
15 \\
20 \\
20 \\
15 \\
15 \\
15 \\
15 \\
35 \\
75 \\
75 \\
15\end{array}$ & $\begin{array}{r}10 \\
75 \\
<5 \\
75 \\
20 \\
85 \\
15 \\
15 \\
15 \\
<5 \\
5 \\
75 \\
20 \\
2\end{array}$ & $\begin{array}{r}50 \\
75 \\
<10 \\
350 \\
150 \\
200 \\
150 \\
20 \\
75 \\
<10 \\
10 \\
75 \\
10 \\
<10\end{array}$ & $\begin{array}{r}750 \\
500 \\
750 \\
500 \\
750 \\
500 \\
500 \\
500 \\
500 \\
500 \\
3,500 \\
3,500 \\
3,500 \\
3,500\end{array}$ & $\begin{array}{r}\mathbf{7 5 0} \\
\mathbf{5 0 0} \\
750 \\
\mathbf{5 0 0} \\
\mathbf{7 5 0} \\
\mathbf{5 0 0} \\
\mathbf{5 0 0} \\
\mathbf{5 0 0} \\
\mathbf{5 0 0} \\
\mathbf{5 0 0} \\
\mathbf{7 5 0} \\
\mathbf{1}, 000 \\
\mathbf{7 5 0} \\
\mathbf{7 5 0}\end{array}$ & $\begin{array}{r}75 \\
200 \\
75 \\
350 \\
150 \\
200 \\
150 \\
150 \\
150 \\
50 \\
75 \\
350 \\
150 \\
75\end{array}$ & $\begin{array}{r}1.500 \\
150 \\
3,500 \\
350 \\
750 \\
350 \\
1,500 \\
750 \\
3,500 \\
3,500 \\
1,500 \\
750 \\
750 \\
3,500\end{array}$ \\
\hline
\end{tabular}

Argillaceous phosphate rock

\begin{tabular}{|c|c|c|c|c|c|c|c|c|c|c|}
\hline $\begin{array}{r}54-5653 \\
5654 \\
5655 \\
5656 \\
5657 \\
5658- \\
5659 \\
5660- \\
5661 \\
5662- \\
5663 \\
5664 \\
5665 \\
56- \\
\end{array}$ & $\begin{array}{l}172 \\
173 \\
174 \\
175 \\
176 \\
177 \\
178 \\
179 \\
180 \\
181 \\
182 \\
183 \\
184\end{array}$ & $\begin{array}{l}7.50 \\
4.25 \\
.40 \\
7.50 \\
4.25 \\
7.50 \\
5.00 \\
3.75 \\
2.00 \\
.85 \\
5.00 \\
4.25 \\
5.00\end{array}$ & $\begin{array}{r}1,500 \\
2,500 \\
750 \\
2,500 \\
2,500 \\
2,500 \\
1,500 \\
2,500 \\
1,500 \\
1,500 \\
1,500 \\
1,500 \\
1,500\end{array}$ & $\begin{array}{r}75 \\
150 \\
15 \\
150 \\
150 \\
150 \\
150 \\
150 \\
75 \\
75 \\
150 \\
150 \\
150\end{array}$ & $\begin{array}{r}75 \\
100 \\
<5 \\
100 \\
150 \\
150 \\
150 \\
150 \\
150 \\
350 \\
350 \\
350 \\
150\end{array}$ & $\begin{array}{r}75 \\
75 \\
<10 \\
75 \\
50 \\
20 \\
100 \\
20 \\
150 \\
1,000 \\
100 \\
150 \\
75\end{array}$ & $\begin{array}{r}3,500 \\
3,500 \\
500 \\
5,000 \\
3,500 \\
1,500 \\
1,500 \\
1,500 \\
1,500 \\
1,500 \\
1,000 \\
750 \\
500\end{array}$ & $\begin{array}{r}1,500 \\
1,500 \\
150 \\
1,500 \\
1,500 \\
1,500 \\
1,500 \\
1,500 \\
1,000 \\
750 \\
3,500 \\
1,500 \\
1,500\end{array}$ & $\begin{array}{l}150 \\
100 \\
<10 \\
150 \\
150 \\
150 \\
150 \\
200 \\
200 \\
750 \\
350 \\
150 \\
350\end{array}$ & $\begin{array}{r}1,500 \\
750 \\
750 \\
3,500 \\
1,500 \\
2,000 \\
1,500 \\
1,500 \\
750 \\
750 \\
1,000 \\
750 \\
1,000\end{array}$ \\
\hline
\end{tabular}


TABLE 2.-Phosphorus and minor-element content of samples from the Treade Peak Phosphatic Shale Member of the Phosphoria Formation-Continued

\begin{tabular}{|c|c|c|c|c|c|c|c|c|c|c|}
\hline \multicolumn{2}{|c|}{ Sample } & \multicolumn{9}{|c|}{ Constituents } \\
\hline Lab. No. & Fleld No. & $\mathbf{P}$ & $\mathbf{Z n}$ & $\mathrm{Ou}$ & N1 & $\mathrm{Mn}$ & $\mathrm{V}$ & $\mathrm{Cr}$ & $\mathrm{Ba}$ & Sr \\
\hline \multicolumn{11}{|c|}{$\begin{array}{l}\text { SAMPLES OF WEATHFRED ROCK, FROM TRENCH-Continued } \\
\text { Phosphatic madstone }\end{array}$} \\
\hline 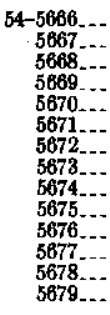 & $\begin{array}{l}185 \\
186 \\
187 \\
188 \\
189 \\
190 \\
191 \\
192 \\
193 \\
194 \\
195 \\
196 \\
197 \\
198\end{array}$ & $\begin{array}{r}10.00 \\
.85 \\
3.75 \\
3.75 \\
3.00 \\
2.00 \\
1.50 \\
3.75 \\
5.00 \\
3.75 \\
1.50 \\
2.00 \\
3.00 \\
5.00\end{array}$ & $\begin{array}{r}\mathbf{7 5 0} \\
1,500 \\
500 \\
500 \\
500 \\
750 \\
750 \\
500 \\
500 \\
500 \\
500 \\
500 \\
400 \\
300\end{array}$ & $\begin{array}{r}75 \\
75 \\
100 \\
75 \\
75 \\
100 \\
150 \\
100 \\
100 \\
150 \\
150 \\
75 \\
150 \\
150\end{array}$ & \begin{tabular}{r|r|}
50 \\
350 \\
150 \\
50 \\
35 \\
100 \\
150 \\
150 \\
75 \\
75 \\
100 \\
75 \\
75 \\
75 \\
75
\end{tabular} & $\begin{array}{r}100 \\
1,000 \\
200 \\
20 \\
20 \\
200 \\
75 \\
50 \\
75 \\
20 \\
15 \\
15 \\
15 \\
15\end{array}$ & $\begin{array}{r}200 \\
750 \\
350 \\
200 \\
200 \\
350 \\
500 \\
750 \\
500 \\
750 \\
750 \\
500 \\
1,000 \\
750\end{array}$ & $\begin{array}{r}750 \\
1,000 \\
500 \\
1,500 \\
750 \\
750 \\
2,000 \\
2,000 \\
2,000 \\
2,000 \\
1,500 \\
750 \\
3,500 \\
2,000\end{array}$ & $\begin{array}{l}100 \\
750 \\
150 \\
350 \\
150 \\
350 \\
750 \\
500 \\
350 \\
350 \\
500 \\
500 \\
500 \\
350 .\end{array}$ & $\begin{array}{r}3,500 \\
750 \\
750 \\
1,000 \\
200 \\
500 \\
500 \\
1,000 \\
1,500 \\
750 \\
500 \\
750 \\
1,000 \\
750\end{array}$ \\
\hline
\end{tabular}

\begin{tabular}{|c|c|c|c|c|c|c|c|c|c|c|}
\hline \multicolumn{11}{|c|}{ Nodular phosphatic mudatone } \\
\hline 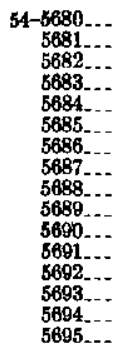 & $\begin{array}{l}199 \\
200 \\
201 \\
202 \\
203 \\
204 \\
205 \\
206 \\
207 \\
208 \\
209 \\
210 \\
211 \\
212 \\
213 \\
214\end{array}$ & $\begin{array}{l}0.60 \\
3.00 \\
3.75 \\
1.25 \\
2.00 \\
1.00 \\
.40 \\
.40 \\
4.25 \\
.75 \\
4.25 \\
7.50 \\
4.25 \\
7.50 \\
5.00 \\
5.00\end{array}$ & $\begin{array}{r}400 \\
1,000 \\
1,000 \\
1,000 \\
1,000 \\
750 \\
750 \\
750 \\
500 \\
760 \\
1,000 \\
750 \\
750 \\
750 \\
750 \\
750\end{array}$ & $\begin{array}{r}100 \\
150 \\
150 \\
150 \\
100 \\
75 \\
50 \\
150 \\
150 \\
150 \\
200 \\
150 \\
200 \\
75 \\
75 \\
75\end{array}$ & \begin{tabular}{r|}
$\mathbf{7 5}$ \\
$\mathbf{3 5 0}$ \\
200 \\
150 \\
150 \\
150 \\
100 \\
100 \\
100 \\
150 \\
350 \\
150 \\
200 \\
150 \\
$\mathbf{3 5 0}$ \\
$\mathbf{7 5}$
\end{tabular} & $\begin{array}{r}15 \\
350 \\
150 \\
75 \\
75 \\
75 \\
75 \\
75 \\
75 \\
75 \\
350 \\
100 \\
100 \\
100 \\
1,000 \\
150\end{array}$ & $\begin{array}{r}500 \\
500 \\
1,500 \\
1,000 \\
1,000 \\
500 \\
500 \\
350 \\
1,000 \\
1,500 \\
1,500 \\
750 \\
1,500 \\
350 \\
750 \\
500\end{array}$ & $\begin{array}{r}750 \\
750 \\
1,500 \\
1,500 \\
1,500 \\
750 \\
350 \\
1,500 \\
2,000 \\
750 \\
5,000 \\
1,500 \\
\mathbf{1 , 5 0 0} \\
750 \\
150 \\
750\end{array}$ & $\begin{array}{l}\mathbf{5 0 0} \\
350 \\
350 \\
500 \\
750 \\
750 \\
750 \\
500 \\
150 \\
500 \\
350 \\
150 \\
150 \\
100 \\
350 \\
150\end{array}$ & $\begin{array}{r}750 \\
750 \\
750 \\
500 \\
1,000 \\
350 \\
200 \\
350 \\
750 \\
350 \\
750 \\
3.500 \\
750 \\
1,000 \\
150 \\
750\end{array}$ \\
\hline \multicolumn{11}{|c|}{ Calcareous mudstone } \\
\hline 54-5696... & 215 & 0.25 & 750 & 75 & 350 & 1,500 & 750 & 500 & 350 & 200 \\
\hline \multicolumn{11}{|c|}{ Nodular phosphatic madatone } \\
\hline 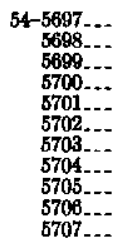 & $\begin{array}{l}216 \\
217 \\
218 \\
219 \\
220 \\
221 \\
222 \\
223 \\
224 \\
225 \\
226\end{array}$ & $\begin{array}{l}2.50 \\
7.50 \\
4.25 \\
2.00 \\
3.75 \\
.75 \\
2.00 \\
4.25 \\
2.00 \\
3.00 \\
2.00\end{array}$ & $\begin{array}{r}380 \\
750 \\
300 \\
300 \\
750 \\
1,250 \\
1,000 \\
1,250 \\
1,250 \\
2,500 \\
2,500\end{array}$ & $\begin{array}{r}75 \\
75 \\
150 \\
150 \\
200 \\
150 \\
150 \\
350 \\
100 \\
150 \\
100\end{array}$ & $\begin{array}{r}50 \\
350 \\
10 \\
50 \\
75 \\
200 \\
200 \\
350 \\
150 \\
350 \\
350\end{array}$ & $\begin{array}{r}50 \\
750 \\
50 \\
50 \\
75 \\
75 \\
20 \\
20 \\
100 \\
\mathbf{3 5 0} \\
\mathbf{5 0 0}\end{array}$ & $\begin{array}{r}350 \\
350 \\
200 \\
500 \\
350 \\
350 \\
750 \\
750 \\
750 \\
1,000 \\
500\end{array}$ & $\begin{array}{r}750 \\
1.000 \\
1,500 \\
1,500 \\
1,500 \\
1,000 \\
1,500 \\
2,000 \\
1,000 \\
1,500 \\
1,500\end{array}$ & $\begin{array}{l}350 \\
150 \\
100 \\
350 \\
150 \\
500 \\
350 \\
200 \\
100 \\
350 \\
350\end{array}$ & $\begin{array}{r}\mathbf{7 5 0} \\
1, \mathbf{0 0 0} \\
\mathbf{7 6 0} \\
\mathbf{5 0 0} \\
\mathbf{5 0 0} \\
\mathbf{3 6 0} \\
\mathbf{5 0 0} \\
\mathbf{7 6 0} \\
\mathbf{7 5 0} \\
1, \mathbf{5 0 0} \\
\mathbf{7 6 0}\end{array}$ \\
\hline
\end{tabular}


TABLE 2.-Phosphorus and minor-element content of samples from the Meade Peak Phosphatic Shale Member of the Phosphoria Formation-Continued

\begin{tabular}{c|c|c|c|c|c|c|c|c|c|c}
\hline Sample & \multicolumn{10}{c}{ Constituents } \\
\hline Lab. No. Fteld No. & P & Zn & Cu & Ni & Mn & V & Or & Ba & gr \\
\hline
\end{tabular}

SAMPLES OF WEATHFRED ROCK, FROM TRENCH-Continued

Phosphatic mudstone

\begin{tabular}{|c|c|c|c|c|c|c|c|c|c|c|}
\hline $\begin{array}{r}54-5708 \\
5709 \ldots \\
5710 \ldots \\
5711 \ldots \\
5712 \ldots \\
5713 \ldots \\
5714 \ldots \\
5715 \ldots \\
5716 \ldots \\
5717 \ldots \\
5718 \ldots \\
5719 \ldots \\
5720 \ldots\end{array}$ & $\begin{array}{l}227 \\
228 \\
229 \\
230 \\
231 \\
232 \\
233 \\
234 \\
235 \\
236 \\
237 \\
238 \\
239\end{array}$ & $\begin{array}{r}0.15 \\
.75 \\
.25 \\
.25 \\
.75 \\
.50 \\
3.00 \\
.40 \\
.50 \\
.75 \\
3.00 \\
.40 \\
.40\end{array}$ & $\begin{array}{r}250 \\
1,250 \\
750 \\
750 \\
1,000 \\
750 \\
2,000 \\
1,000 \\
750 \\
400 \\
750 \\
400 \\
200\end{array}$ & $\begin{array}{r}10 \\
75 \\
75 \\
50 \\
75 \\
150 \\
150 \\
100 \\
75 \\
100 \\
150 \\
100 \\
35\end{array}$ & $\begin{array}{r}100 \\
100 \\
100 \\
75 \\
150 \\
150 \\
750 \\
150 \\
100 \\
75 \\
150 \\
75 \\
50\end{array}$ & $\begin{array}{r}100 \\
100 \\
100 \\
200 \\
50 \\
15 \\
3,500 \\
350 \\
15 \\
10 \\
75 \\
15 \\
10\end{array}$ & $\begin{array}{r}20 \\
200 \\
150 \\
50 \\
500 \\
1,000 \\
1,500 \\
500 \\
360 \\
350 \\
350 \\
500 \\
350\end{array}$ & $\begin{array}{r}150 \\
750 \\
350 \\
150 \\
750 \\
1,000 \\
1,500 \\
1,000 \\
500 \\
750 \\
1,500 \\
350 \\
350\end{array}$ & $\begin{array}{r}<10 \\
200 \\
50 \\
35 \\
350 \\
500 \\
750 \\
500 \\
500 \\
500 \\
200 \\
500 \\
500\end{array}$ & $\begin{array}{l}350 \\
150 \\
100 \\
150 \\
350 \\
150 \\
750 \\
350 \\
350 \\
350 \\
760 \\
200 \\
350\end{array}$ \\
\hline
\end{tabular}

Arcillaceons phosphate rock

\begin{tabular}{|c|c|c|c|c|c|c|c|c|c|c|}
\hline $\begin{array}{r}\text { 54-5721... } \\
5722 \\
5723 \ldots \\
5724 \\
5725 \ldots \\
5726 . . \\
5727 \\
5728 \\
5729 \\
5730 \\
5731 \\
5732 \\
5\end{array}$ & $\begin{array}{l}240 \\
241 \\
242 \\
243 \\
244 \\
245 \\
246 \\
247 \\
248 \\
249 \\
250 \\
251\end{array}$ & $\begin{array}{l}2.00 \\
5.00 \\
4.25 \\
2.50 \\
4.25 \\
1.25 \\
7.50 \\
.25 \\
3.00 \\
7.50 \\
3.00 \\
2.00\end{array}$ & $\begin{array}{r}400 \\
300 \\
300 \\
750 \\
300 \\
2,000 \\
300 \\
400 \\
750 \\
750 \\
750 \\
1,250\end{array}$ & $\begin{array}{l}200 \\
200 \\
150 \\
350 \\
200 \\
350 \\
350 \\
350 \\
500 \\
350 \\
150 \\
150\end{array}$ & $\begin{array}{r}75 \\
350 \\
75 \\
350 \\
75 \\
350 \\
75 \\
350 \\
75 \\
100 \\
150 \\
350\end{array}$ & $\begin{array}{r}10 \\
10 \\
<10 \\
10 \\
10 \\
15 \\
<10 \\
20 \\
10 \\
10 \\
20 \\
350\end{array}$ & $\begin{array}{r}750 \\
1,000 \\
750 \\
1,500 \\
500 \\
1,500 \\
1,000 \\
3,500 \\
3,500 \\
3,500 \\
1,500 \\
500\end{array}$ & $\begin{array}{r}2,000 \\
3,500 \\
1,000 \\
2,000 \\
1,500 \\
1,500 \\
2,000 \\
5,000 \\
1,500 \\
1,500 \\
1,000 \\
500\end{array}$ & $\begin{array}{l}200 \\
150 \\
150 \\
150 \\
150 \\
350 \\
100 \\
350 \\
150 \\
100 \\
150 \\
150\end{array}$ & $\begin{array}{r}2,000 \\
2,000 \\
1,500 \\
2,000 \\
2,000 \\
350 \\
3,500 \\
500 \\
500 \\
750 \\
750 \\
350\end{array}$ \\
\hline
\end{tabular}

Calcareous mudetone

\begin{tabular}{rr|r|r|r|r|r|r|r|r}
\hline $54-5733$ & 252 & 2.00 & 400 & 50 & 35 & 100 & 350 & 350 & 35 \\
$5734-$ & 253 & 5.00 & 1,000 & 150 & 150 & 75 & 750 & 750 & 200 \\
$5735 \ldots$ & 254 & .75 & 750 & 7 & 5 & 100 & 100 & 150 & 35 \\
\hline
\end{tabular}

Argillaceous phoephate rock

\begin{tabular}{|c|c|c|c|c|c|c|c|c|c|c|}
\hline $\begin{array}{r}54-5736 \\
5737 \ldots \\
5738 \ldots \\
5739 \ldots \\
5740 \\
5741 \ldots \\
5742 \\
5743 \ldots \\
5747 \ldots \\
5748 \\
5749 \\
5750 \ldots \\
\end{array}$ & $\begin{array}{l}255 \\
256 \\
257 \\
258 \\
259 \\
260 \\
261 \\
262 \\
529 \\
530 \\
531 \\
532\end{array}$ & $\begin{array}{l}7.50 \\
7.50 \\
4.25 \\
5.00 \\
7.50 \\
2.00 \\
7.50 \\
7.50 \\
5.00 \\
5.00 \\
2.00 \\
7.50\end{array}$ & $\begin{array}{r}750 \\
1,500 \\
1,500 \\
1,250 \\
1,500 \\
750 \\
1,260 \\
1,250 \\
750 \\
1,000 \\
1,250 \\
1,250\end{array}$ & $\begin{array}{r}100 \\
150 \\
100 \\
100 \\
100 \\
20 \\
100 \\
75 \\
75 \\
100 \\
100 \\
150\end{array}$ & $\begin{array}{r}50 \\
35 \\
100 \\
100 \\
75 \\
20 \\
150 \\
100 \\
75 \\
100 \\
150 \\
100\end{array}$ & $\begin{array}{r}15 \\
10 \\
150 \\
20 \\
10 \\
150 \\
10 \\
75 \\
75 \\
20 \\
600 \\
200\end{array}$ & $\begin{array}{r}1,000 \\
3,500 \\
3,500 \\
2,000 \\
2,000 \\
750 \\
2,000 \\
1,500 \\
350 \\
1,000 \\
1,000 \\
1,500\end{array}$ & $\begin{array}{r}\mathbf{7 5 0} \\
1,000 \\
\mathbf{7 5 0} \\
\mathbf{5 0 0} \\
\mathbf{7 5 0} \\
\mathbf{3 5 0} \\
\mathbf{7 5 0} \\
\mathbf{7 6 0} \\
\mathbf{5 0 0} \\
\mathbf{7 5 0} \\
\mathbf{3 5 0} \\
\mathbf{1 , 0 0 0}\end{array}$ & $\begin{array}{r}75 \\
150 \\
150 \\
150 \\
150 \\
20 \\
75 \\
75 \\
75 \\
100 \\
75 \\
150\end{array}$ & $\begin{array}{l}500 \\
750 \\
750 \\
350 \\
750 \\
350 \\
500 \\
500 \\
350 \\
750 \\
150 \\
750\end{array}$ \\
\hline
\end{tabular}

Phosphate rock

\begin{tabular}{|c|c|c|c|c|c|c|c|c|c|c|}
\hline $\begin{array}{r}\text { b4-5795. } \\
5796 \\
5797\end{array}$ & $\begin{array}{l}722 \\
728 \\
724\end{array}$ & $\begin{array}{l}15.00 \\
15.00 \\
15.00\end{array}$ & $\begin{array}{l}1,500 \\
1,500 \\
1,000\end{array}$ & $\begin{array}{r}75 \\
100 \\
75\end{array}$ & $\begin{array}{l}35 \\
75 \\
20\end{array}$ & $\begin{array}{r}20 \\
200 \\
15\end{array}$ & $\begin{array}{l}3,500 \\
3,500 \\
\mathbf{3}, 500\end{array}$ & $\begin{array}{r}760 \\
1,000 \\
760\end{array}$ & $\begin{array}{l}\mathbf{7 5} \\
\mathbf{7 5} \\
\mathbf{7 5}\end{array}$ & $\begin{array}{l}2,000 \\
1,500 \\
1,500\end{array}$ \\
\hline
\end{tabular}


For the elements reported, ranges of concentration in the samples listed in table 2 are as follows (phosphorus expressed in percent, other elements in parts per million):

\begin{tabular}{|c|c|c|}
\hline \multicolumn{2}{|c|}{ In unweathered rock } & In weathered rock \\
\hline Phosphorus - & $0.1-15$ & 0.1-15 \\
\hline Zine --1---1-- & $20-7,000$ & $200-2,500$ \\
\hline Copper -............ & $<1-150$ & $7-500$ \\
\hline Nickel & $<5-350$ & $<5-750$ \\
\hline Manganese -- & $10-500$ & $<10-3,500$ \\
\hline Vanadium - & $35-5,000$ & $20-5,000$ \\
\hline Chromium … & $50-2,000$ & $150-5,000$ \\
\hline Barium 기 & $<5-500$ & $<10-750$ \\
\hline Strontium - - & $100-3,500$ & $100-3,500$ \\
\hline
\end{tabular}

When analyses of the samples of unweathered rock listed in table 2 are arranged in the numerical sequence of the phosphorus values obtained, several possibilities are disclosed for initial relations among individual elements and also between certain elements and certain rock types. It must be remembered, however, that although the lithologic designation of each rock unit given in table 2 and plate 1 is applicable to the unit as a whole, single samples within a group may vary somewhat, lithologically, from the majority of samples taken from the unit.

In the 93 samples of unweathered rock that were analyzed in this study, the lowest phosphorus content, 0.1 percent, was in 3 samples of phosphatic mudstone; the highest, 15 percent, was in 3 samples of phosphate rock. The median phosphorus content is 3 percent, which was the content of 6 samples of mudstone, 2 of which are nodular and 1 of which is highly calcareous. The first quartile value is 1.5 percent, which was the content of 7 samples, 3 of which were taken from nodular phosphatic mudstone, and 4 of which were taken from argillaceous phosphate rock. The third quartile value is 7.5 percent, which was the content of 16 samples, 8 from argillaceous phosphate rock, 7 from phosphate rock, and 1 from nodular phosphatic mudstone.

The nine highest zinc values determined-ranging from 3,000 to 7,000 ppm (parts per million) - were in argillaceous rocks that contained 3.75 to 7.5 percent phosphorus, values that are above the median but well below the maximum concentration of phosphorus measured. The two lowest zinc values determined--20 and $50 \mathrm{ppm}$-were for samples that had the two minimum phosphorus values. Only one sample that had a zine value of less than $200 \mathrm{ppm}$ had a phosphorus content above the first quartile value, and none of the samples that had contained less than $200 \mathrm{ppm}$ zinc had a phosphorus value above the median of 3 percent. 
The distributions of nickel and chromium--and, to some extent, of barium-are similar to the distribution of zine in that most of the minimal values of these elements are in rocks having the lowest phosphorus values, and the maximal values are in argillaceous rocks having only moderately high phosphorus values. From these facts it seems that in the unweathered shale beds of the Meade Peak Member of the Phosphoria Formation, zinc, nickel, chromium, and possibly barium have a rough positive correlation with phosphorus in rocks of high argillaceous content.

Both vanadium and strontium, especially the latter, seem to show positive correlation with phosphorus regardless of lithology. The four minimum values of each of these two elements were determined in rocks which had a phosphorus content less than the first-quartile phosphorus value of 1.5 percent. The eight high values of each were in rocks of high phosphorus content-maximal vanadium in rocks having from 5 to 15 percent phosphorus, and maximal strontium in rocks having 7.5 to 15 percent phosphorus.

An inverse correlation between manganese and phosphorus seems possible; with one exception the highest manganese values were in rocks whose phosphorus content was 2 percent or less, whereas the five lowest manganese values were in rocks whose phosphorus content was 7.5 percent or more.

No definite relations are obvious between content of phosphorus and the contents of other elements, which seem to be randomly distributed relative to phosphorus.

On plate 1, histograms of average values computed from analytical results on groups of samples from the mine are shown beside histograms of average values computed from analytical results on corresponding groups of samples from the trench. Each group averaged represents a lithologic unit. Inspection of this figure shows that for the section as a whole there seem to be no consistent or significant differences between unweathered and weathered rock in content of zinc, managanese, vanadium, and strontium. In most of the rock units studied, weathering apparently has concentrated chromium, barium, copper, and possibly nickel.

The effect of weathering on the mobility of elements seems to be related to the character of the rock being weathered. In the 12-inch marker bed of highly calcareous mudstone 84 feet from the chert, amounts of manganese, barium, and nickel have greatly increased during weathering, but strontium, chromium, and phosphorus have decreased. The only weathered rock unit strikingly enriched in phosphorus is the high-grade phosphate rock 159 feet from the chert; this unit shows little or no enrichment in other elements. Barium shows its 
greatest increase with weathering in the mudstone units, including the calcareous unit mentioned above. Chromium shows some increase in all the weathered mudstone units except the highly calcareous ones, but its maximum increase is in the argillaceous phosphate rock in the interval 116 to 121 feet from the chert-a unit which also shows considerable enrichment in strontium, nickel, and copper. The adjoining unit 121 to 128 feet from the chert, also argillaceous phosphate rock, shows a great enrichment in vanadium, considerable enrichment in copper, and some in nickel and chromium.

\section{STUDY OF SAMPLES FROM COMPLETE PROFILES}

From short trenches dug into the banks of trenches 1 and 2 (figs. 2-4), complete profile samples were collected at 19 sites over the phosphatic shale beds of the Meade Peak Member of the Phosphoria Formation. The locations of these short trenches were determined by the availability of the plant species that had been chosen for study. In the aggregate, the samples from these sites provide data across the entire section of phosphatic shales exposed in the region. The technique used to sample the colluvially dragged shales and the soils was described by the U.S. Soil Survey Staff $(1951$, p. 330).

For purposes of comparison, soil and vegetation samples were also collected at three sites over the carbonate rock of the Grandeur Tongue of the Park City Formation upslope from the outcrop of the phosphatic shales, where it is believed that metal from the shales can not have enriched the colluvium. One representative sample-sample 785-was taken from the outcropping weathered carbonate bedrock to learn in what amounts the elements determined in the colluvial soil had been present in the source rock from which the colluvium was derived.

Data from the analyses are reported in table 3, in which the complete profile at each site (including analytical results on shrubs) is shown as a unit. In this table, the lowermost part of the $\mathrm{C}$ horizon is the bottom of the soil; DSh designates the colluvially dragged layers of shale, and BR designates bedrock in place.

\section{BEDROCK}

Of the bedrock samples included in the complete profiles from the 19 sites over the phosphatic shales, all but 2 (those at sites 1 and 22) have already been reported in table 2 and plate 1 . To the information in the previous section, therefore, little is added here toward elarification of relations between elements within the Meade Peak Member of the Phosphoria Formation. Only one new figure is supplied by the results from analysis of these two bedrock samples: a different maximum for phosphorus in the weathered shales studied 
is the 18 percent of phosphorus in the bedrock sample from site 22.

The analysis of the sample of weathered carbonate bedrock from the Grandeur Tongue of the Park City Formation indicates the probable metal content of the colluvium from which the soil was derived. The values for the respective metals in general are near the minimum of the ranges in the phosphatic shale samples.

TABLE 3.-Phosphorus and minor-element content of samples of 22 complete profiles and one bedrock exposure near Montpelier, Idaho

[Type of sample: 8, P, and C denote shrub species Symphoricarpos, Pachistima, and Ceanothus; Y and $O$ show type of growth, young and old; $A_{00}$ and $A_{0}$ are layers of unconsolidated organic materfal (humus) on the ground suriace, which in column headed "Dopth" is designated by $0 ; \mathbf{A}_{1}, \mathbf{A}_{11}, \mathbf{A}_{12}, \mathrm{AC}_{1} \mathrm{C}_{1}, \mathrm{C}_{2}, \mathrm{C}_{3}$ and $C_{4}$ are soll horizons, DSh is dragged shale, and BR is bedrock. Depth of sample: Asterisk indicates plant sample; no depth recorded. Phosphorus content is expressed in percent; trace elements are in parts per million. Leaders mesn not determined]

\begin{tabular}{|c|c|c|c|c|c|c|c|c|c|c|c|c|}
\hline \multicolumn{4}{|c|}{ Sample } & \multicolumn{9}{|c|}{ Constituent } \\
\hline $\begin{array}{l}\text { Lab. } \\
\text { No. }\end{array}$ & $\begin{array}{l}\text { Field } \\
\text { No. }\end{array}$ & Type & $\begin{array}{c}\text { Depth } \\
\text { (1nehes) }\end{array}$ & $\mathrm{Cu}$ & $\mathrm{Zn}$ & $\mathrm{v}$ & $\mathrm{Cr}$ & $\mathrm{Mn}$ & Ni & $\mathrm{Sr}$ & $\mathrm{Ba}$ & $\mathbf{P}$ \\
\hline
\end{tabular}

PROFILES ABOVE PHOSPHORIA FORMATION

Profile at site 1

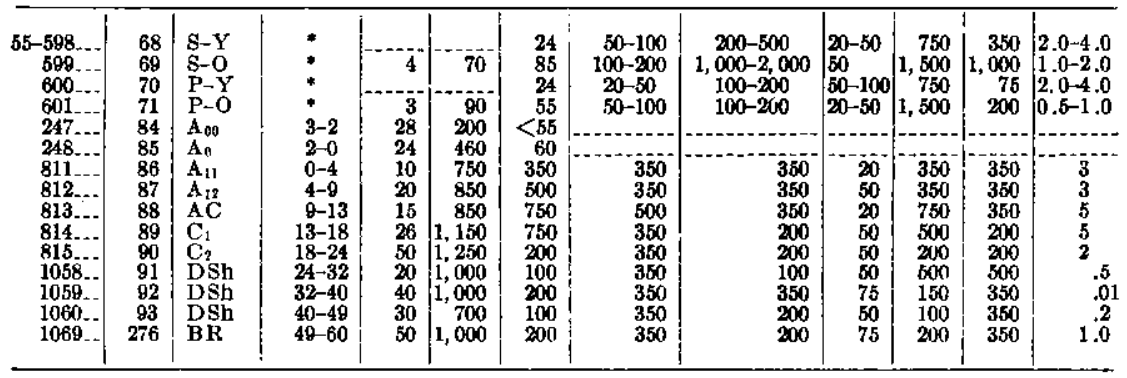

Profle at site 2

\begin{tabular}{|c|c|c|c|c|c|c|c|c|c|c|c|c|}
\hline $\begin{array}{r}55-602 \\
603 \\
249 \\
250 \\
816 \\
817 \\
818 \\
1061 \\
1062 \\
1063 \\
1064 \\
1065 \\
1066 \\
1067 \\
1068 \\
54-5629 .\end{array}$ & $\begin{array}{r}72 \\
73 \\
263 \\
264 \\
265 \\
266 \\
267 \\
268 \\
269 \\
270 \\
271 \\
272 \\
273 \\
274 \\
275 \\
148\end{array}$ & $\begin{array}{l}C-Y \\
C-O \\
A_{00} \\
A_{0} \\
A_{11} \\
A_{11} \\
C \\
D S h \\
D S h \\
D \& h \\
D \& b \\
D S h \\
D S h \\
D S h \\
D S h \\
\text { BR }\end{array}$ & $\begin{array}{c}* \\
* \\
3-1.5 \\
1.5-0 \\
0-6 \\
6-9 \\
9-14 \\
14-18 \\
18-23 \\
23-28 \\
28-30 \\
30-35 \\
35-42 \\
42-49 \\
40-59 \\
>59\end{array}$ & $\begin{array}{r}3 \\
1 \\
19 \\
22 \\
12 \\
15 \\
36 \\
80 \\
120 \\
50 \\
30 \\
50 \\
40 \\
50 \\
30 \\
15\end{array}$ & $\begin{array}{r}30 \\
11 \\
190 \\
520 \\
600 \\
550 \\
750 \\
700 \\
1,400 \\
1,200 \\
1,400 \\
1,200 \\
1,200 \\
1,400 \\
1,200 \\
1,600\end{array}$ & $\begin{array}{r}42 \\
44 \\
>59 \\
122 \\
150 \\
200 \\
200 \\
200 \\
1,500 \\
1,000 \\
1,000 \\
1.000 \\
750 \\
200 \\
200 \\
350\end{array}$ & $\begin{array}{r}20-50 \\
50-100 \\
135 \\
218 \\
200 \\
200 \\
350 \\
760 \\
1,000 \\
760 \\
500 \\
750 \\
500 \\
360 \\
350 \\
350\end{array}$ & $\begin{array}{r}200-500 \\
200-500 \\
100 \\
500 \\
200 \\
360 \\
200 \\
75 \\
60 \\
200 \\
360 \\
200 \\
150 \\
860 \\
160 \\
75\end{array}$ & $\begin{array}{r}20-50 \\
20-60 \\
27 \\
50 \\
15 \\
20 \\
50 \\
50 \\
50 \\
50 \\
50 \\
75 \\
50 \\
75 \\
100 \\
50\end{array}$ & \begin{tabular}{r}
750 \\
2,000 \\
\hdashline-2. \\
\hdashline 200 \\
200 \\
350 \\
350 \\
1,000 \\
750 \\
750 \\
750 \\
750 \\
350 \\
150 \\
200
\end{tabular} & \begin{tabular}{c}
100 \\
200 \\
\hdashline-2. \\
\hdashline 350 \\
350 \\
200 \\
150 \\
100 \\
100 \\
200 \\
150 \\
100 \\
200 \\
200 \\
750
\end{tabular} & $\begin{array}{r}1.0-2.0 \\
1.0-2.0 \\
1.8 \\
1.2 \\
2.0 \\
3.0 \\
5.0 \\
4.0 \\
13.0 \\
10.0 \\
10.0 \\
1.0 \\
3.0 \\
1.0 \\
2.00\end{array}$ \\
\hline
\end{tabular}


TABLE 3.-Phosphorus and minor-element content of samples of 22 complete profiles and one bedrock exposure near Montpelier, Idaho-Continued

\begin{tabular}{c|c|c|c|c|c|c|c|c|c|c|c|c}
\hline \multicolumn{7}{c|}{ Sample } & \multicolumn{7}{c}{ Constituent } \\
\hline $\begin{array}{c}\text { Lab. } \\
\text { No. }\end{array}$ & $\begin{array}{c}\text { Field } \\
\text { No. }\end{array}$ & Type & $\begin{array}{c}\text { Depth } \\
\text { (inches) }\end{array}$ & Cu & Zn & V & Cr & Mn & Ni & Sr & Ba & P \\
\hline
\end{tabular}

PROFILES ABOVE PHOSPEORL FORMATION-Continued

Profle at site 3

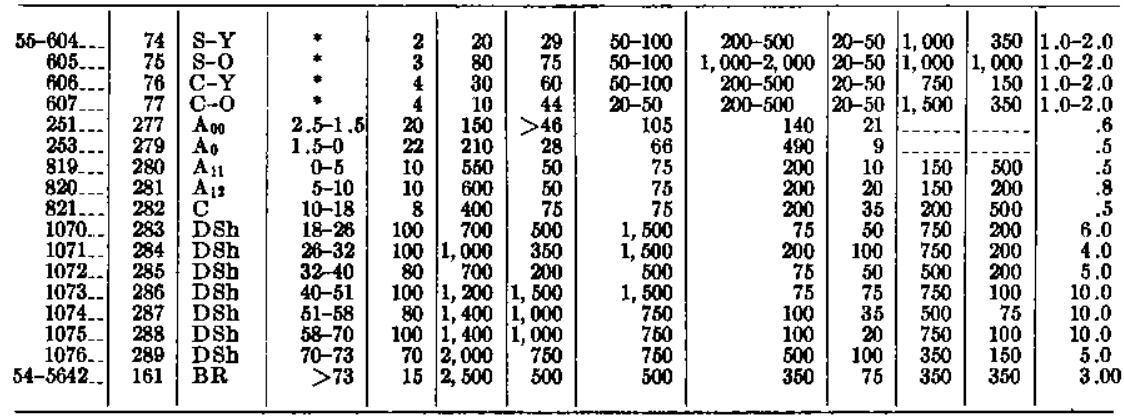

Profile at wite 4

\begin{tabular}{|c|c|c|c|c|c|c|c|c|c|c|c|c|}
\hline 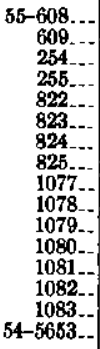 & $\begin{array}{r}78 \\
79 \\
290 \\
291 \\
292 \\
293 \\
294 \\
295 \\
296 \\
297 \\
298 \\
299 \\
300 \\
301 \\
302 \\
172\end{array}$ & $\begin{array}{l}\text { S-Y } \\
\text { S-O } \\
A_{00} \\
A_{0} \\
A_{11} \\
A_{19} \\
\text { AC } \\
\text { C } \\
\text { DBh } \\
\text { DSh } \\
\text { DSh } \\
\text { DSh } \\
\text { DSh } \\
\text { DBh } \\
\text { DSh } \\
\text { BR }\end{array}$ & $\begin{array}{c}* \\
* \\
3-1.5 \\
1.5-0 \\
0-5 \\
5-10 \\
10-14 \\
14-24 \\
24-32 \\
32-41 \\
41-52 \\
52-58 \\
58-65 \\
65-68 \\
68-78 \\
>78\end{array}$ & $\begin{array}{r}6 \\
14 \\
24 \\
50 \\
12 \\
18 \\
10 \\
70 \\
100 \\
100 \\
120 \\
120 \\
120 \\
100 \\
75\end{array}$ & $\begin{array}{r}80 \\
180 \\
360 \\
575 \\
600 \\
475 \\
600 \\
1,000 \\
800 \\
1,000 \\
1,200 \\
1,200 \\
2,000 \\
1,000 \\
1,500\end{array}$ & $\begin{array}{r}21 \\
100 \\
30 \\
38 \\
50 \\
100 \\
100 \\
150 \\
1,500 \\
500 \\
350 \\
1,000 \\
1,500 \\
3,500 \\
1,600 \\
3,500\end{array}$ & $\begin{array}{r}50-100 \\
100-200 \\
30 \\
69 \\
75 \\
75 \\
75 \\
75 \\
1,000 \\
1,000 \\
1,500 \\
1,000 \\
1,000 \\
2,000 \\
750 \\
1,500\end{array}$ & $\begin{array}{r}100-200 \\
1,000-2,000 \\
250 \\
690 \\
500 \\
350 \\
200 \\
200 \\
100 \\
50 \\
50 \\
200 \\
75 \\
100 \\
75 \\
75\end{array}$ & $\begin{array}{r}20-50 \\
20-50 \\
10 \\
23 \\
<5 \\
5 \\
10 \\
20 \\
75 \\
75 \\
75 \\
150 \\
100 \\
150 \\
35 \\
75\end{array}$ & \begin{tabular}{r}
750 \\
1,000 \\
$\cdots \cdots$ \\
\hdashline 200 \\
250 \\
$26 i$ \\
$<b i$ \\
500 \\
350 \\
750 \\
500 \\
750 \\
750 \\
750 \\
1,500
\end{tabular} & \begin{tabular}{r}
200 \\
2,000 \\
\hdashline-2 \\
\hdashline 750 \\
750 \\
500 \\
150 \\
100 \\
100 \\
150 \\
150 \\
100 \\
100 \\
75 \\
150
\end{tabular} & $\begin{array}{r}2.0-4.0 \\
1.0-2.0 \\
.22 \\
.03 \\
.3 \\
.3 \\
.3 \\
.6 \\
9.0 \\
4.0 \\
8.0 \\
5.0 \\
6.0 \\
5.0 \\
17.0 \\
7.5\end{array}$ \\
\hline
\end{tabular}

Profle at wite 8

\begin{tabular}{|c|c|c|c|c|c|c|c|c|c|c|c|c|}
\hline $\begin{array}{r}56-614 \\
615 \\
260 \\
261 \\
834 \\
835 \\
836 \\
1103 \\
1104 \\
1105 \\
1106 \\
54-5651 \\
4\end{array}$ & $\begin{array}{r}94 \\
95 \\
334 \\
336 \\
336 \\
337 \\
338 \\
339 \\
340 \\
341 \\
342 \\
170\end{array}$ & $\begin{array}{l}\text { C-Y } \\
\text { C-O } \\
\text { A }_{00} \\
\text { A }_{0} \\
\text { A }_{1} \\
\text { AC } \\
\text { C } \\
\text { DSh } \\
\text { DSh } \\
\text { DSh } \\
\text { DSh } \\
\text { BR }\end{array}$ & $\begin{array}{c}: \\
3-2 \\
2-0 \\
0-4 \\
4-9 \\
9-12 \\
12-20 \\
20-27 \\
27-37 \\
37-43 \\
>43\end{array}$ & $\begin{array}{r}2 \\
<1 \\
26 \\
24 \\
12 \\
20 \\
26 \\
160 \\
120 \\
40 \\
60 \\
75\end{array}$ & $\begin{array}{r}30 \\
20 \\
400 \\
350 \\
750 \\
860 \\
850 \\
1,400 \\
1,400 \\
1,400 \\
700 \\
2,500\end{array}$ & $\begin{array}{r}58 \\
37 \\
>140 \\
>117 \\
200 \\
350 \\
350 \\
1,500 \\
3,600 \\
2,000 \\
2,000 \\
3,500\end{array}$ & $\begin{array}{r}50-100 \\
50-100 \\
460 \\
265 \\
200 \\
350 \\
500 \\
1,000 \\
1,000 \\
760 \\
1,000 \\
760\end{array}$ & $\begin{array}{r}200-500 \\
200-500 \\
450 \\
370 \\
350 \\
350 \\
200 \\
50 \\
50 \\
200 \\
350 \\
10\end{array}$ & $\begin{array}{c}50-100 \\
50-100 \\
86 \\
53 \\
5 \\
20 \\
20 \\
75 \\
100 \\
50 \\
50 \\
20\end{array}$ & \begin{tabular}{r}
1,500 \\
3,500 \\
\hdashline 350 \\
7500 \\
500 \\
500 \\
750 \\
500 \\
750 \\
750
\end{tabular} & \begin{tabular}{r}
150 \\
350 \\
$-2-$. \\
\hdashline 500 \\
750 \\
500 \\
150 \\
75 \\
150 \\
100 \\
150
\end{tabular} & $\mid \begin{array}{r}1.0-2.0 \\
0.5-1.0 \\
4.47 \\
1.60 \\
3.0 \\
3.0 \\
4.0 \\
4.0 \\
6.0 \\
8.0 \\
14.0 \\
5.00\end{array}$ \\
\hline
\end{tabular}

Profile at aite 9

\begin{tabular}{|c|c|c|c|c|c|c|c|c|c|c|c|c|}
\hline $\begin{array}{r}55-617 . \\
262 \\
837 . \\
838 \\
830 \\
1107 \\
1108 . \\
1109 . \\
1110 . \\
1111 . \\
54-5656 .\end{array}$ & $\begin{array}{r}97 \\
343 \\
344 \\
345 \\
346 \\
347 \\
348 \\
349 \\
340 \\
361 \\
175\end{array}$ & $\begin{array}{l}\text { C-O } \\
\text { A }_{00} \\
A_{1} \\
A_{C} \\
\text { C } \\
\text { DSh } \\
\text { DSh } \\
\text { DSh } \\
\text { DSh } \\
\text { DSh } \\
\text { BR }\end{array}$ & $\begin{array}{r}* \\
1.5-0 \\
0-4 \\
4-12 \\
12-21 \\
21-26 \\
26-32 \\
32-40 \\
40-47 \\
47-54 \\
>54\end{array}$ & $\begin{array}{r}3 \\
24 \\
18 \\
20 \\
40 \\
160 \\
100 \\
160 \\
160 \\
160 \\
160\end{array}$ & $\begin{array}{r}20 \\
380 \\
675 \\
675 \\
550 \\
1,000 \\
1,000 \\
1,400 \\
1,700 \\
2,000 \\
2,600\end{array}$ & $\begin{array}{r}46 \\
>147 \\
150 \\
200 \\
200 \\
500 \\
750 \\
1,600 \\
2,000 \\
5,000 \\
5,000\end{array}$ & $\begin{array}{r}50-100 \\
470 \\
350 \\
500 \\
760 \\
1,000 \\
1,500 \\
2,000 \\
1,500 \\
1,500 \\
1,500\end{array}$ & $\begin{array}{r}200-600 \\
200 \\
350 \\
350 \\
100 \\
100 \\
150 \\
75 \\
100 \\
75 \\
75\end{array}$ & $\begin{array}{c}50-100 \\
67 \\
10 \\
20 \\
35 \\
100 \\
100 \\
100 \\
150 \\
100 \\
100\end{array}$ & $\begin{array}{r}350 \\
-750 \\
750 \\
750 \\
500 \\
750 \\
750 \\
750 \\
750 \\
3,500\end{array}$ & $\begin{array}{l}360 \\
-750 \\
750 \\
600 \\
150 \\
200 \\
150 \\
100 \\
100 \\
150\end{array}$ & $\begin{array}{c}0.5-1.0 \\
4.70 \\
2.0 \\
1.0 \\
5.0 \\
4.0 \\
4.0 \\
5.0 \\
5.0 \\
6.0 \\
7.5\end{array}$ \\
\hline
\end{tabular}


TABLE 3.-Phosphorus and minor-element content of samples of 22 complete profles and one bedrock exposure near Montpelier, Idaho-Continued

\begin{tabular}{|c|c|c|c|c|c|c|c|c|c|c|c|c|}
\hline \multicolumn{4}{|c|}{ Sample } & \multicolumn{9}{|c|}{ Constituent } \\
\hline $\begin{array}{l}\text { Lab. } \\
\text { No. }\end{array}$ & $\begin{array}{c}\text { Field } \\
\text { No. }\end{array}$ & Type & $\begin{array}{c}\text { Depth } \\
\text { (Inches) }\end{array}$ & $\mathrm{Cu}$ & $\mathbf{Z n}$ & $\mathrm{V}$ & $\mathrm{Cr}$ & Mn & $\mathrm{NI}$ & $8 \mathbf{r}$ & $\mathbf{B a}$ & $\mathbf{P}$ \\
\hline \multicolumn{13}{|c|}{$\begin{array}{c}\text { PROFILES ABOVE PBOSPHORIA FORMATION-Continued } \\
\text { Profile at site } 10\end{array}$} \\
\hline $\begin{array}{r}55-618 . \\
619 . \\
263 . \\
840 \\
841 . \\
842 . \\
843 . \\
1112 . \\
1113 \\
1114 . \\
1115 . \\
1116 . \\
54-5662 .\end{array}$ & $\begin{array}{r}98 \\
99 \\
352 \\
353 \\
354 \\
355 \\
356 \\
357 \\
358 \\
359 \\
360 \\
361 \\
181\end{array}$ & $\begin{array}{l}\text { S-Y } \\
\text { S-O } \\
A_{0} \\
A_{11} \\
A_{12} \\
\text { AC } \\
\text { C } \\
\text { DSh } \\
\text { DSh } \\
\text { DSh } \\
\text { DSh } \\
\text { DSh } \\
\text { BR }\end{array}$ & $\begin{array}{c}* \\
1.5-0 \\
0-4 \\
4-10 \\
10-17 \\
17-26 \\
26-33 \\
38-40 \\
40-46 \\
40-54 \\
54-60 \\
>60\end{array}$ & $\begin{array}{r}4 \\
18 \\
16 \\
15 \\
18 \\
15 \\
60 \\
120 \\
70 \\
100 \\
160 \\
75\end{array}$ & $\begin{array}{r}80 \\
440 \\
600 \\
625 \\
550 \\
475 \\
700 \\
500 \\
700 \\
700 \\
1,000 \\
1,500\end{array}$ & $\begin{array}{r}36 \\
100 \\
89 \\
75 \\
50 \\
75 \\
100 \\
350 \\
350 \\
150 \\
150 \\
500 \\
1,500\end{array}$ & $\begin{array}{r}20-60 \\
100-200 \\
200 \\
150 \\
150 \\
200 \\
350 \\
1,000 \\
2,000 \\
750 \\
1,000 \\
1,500 \\
750\end{array}$ & $\begin{array}{r}200-500 \\
1,000-2,000 \\
520 \\
350 \\
350 \\
200 \\
100 \\
75 \\
20 \\
50 \\
50 \\
50 \\
1,000\end{array}$ & $\mid \begin{array}{r}20-60 \\
20-60 \\
52 \\
10 \\
10 \\
10 \\
10 \\
75 \\
75 \\
60 \\
100 \\
150 \\
350\end{array}$ & \begin{tabular}{r}
1,500 \\
1,500 \\
\hdashline 350 \\
350 \\
350 \\
500 \\
350 \\
750 \\
500 \\
350 \\
500 \\
750
\end{tabular} & \begin{tabular}{r}
200 \\
1,500 \\
\hdashline 750 \\
750 \\
500 \\
350 \\
150 \\
150 \\
150 \\
150 \\
150 \\
750
\end{tabular} & $\begin{array}{r}1.0-2.0 \\
0.5-1.0 \\
1.12 \\
.8 \\
.8 \\
1.0 \\
4.0 \\
3.0 \\
4.0 \\
4.0 \\
6.0 \\
8.0 \\
.85\end{array}$ \\
\hline
\end{tabular}

\section{Proffle at gite 11}

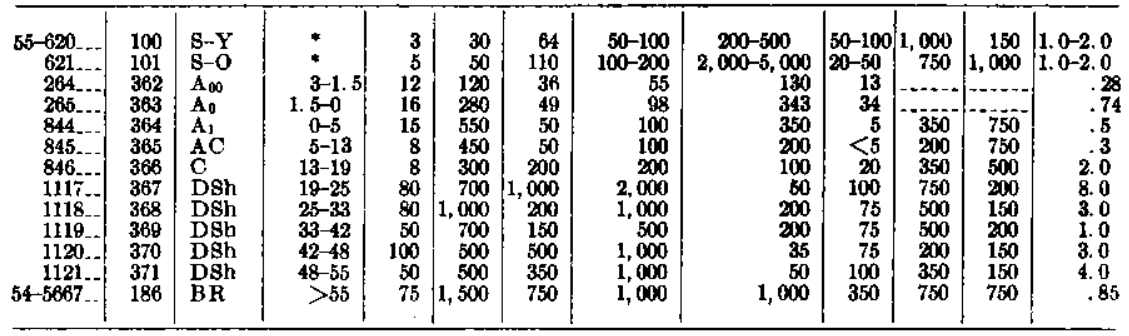

Profile at aite 12

\begin{tabular}{|c|c|c|c|c|c|c|c|c|c|c|c|c|}
\hline $\begin{array}{r}55-622 \ldots \\
623 \\
624 \ldots \\
625 \ldots \\
266 . \\
267 \\
847 \\
848 \\
849 \\
850 \\
1122 \\
1123 \\
1124 \\
1125 \\
1126 \\
1127 \\
1128 \\
1129 \\
54-5675 \\
\end{array}$ & $\begin{array}{l}102 \\
103 \\
104 \\
105 \\
372 \\
373 \\
374 \\
375 \\
376 \\
377 \\
378 \\
379 \\
380 \\
381 \\
382 \\
383 \\
384 \\
385 \\
194\end{array}$ & $\begin{array}{l}C-Y \\
C-O \\
P-Y \\
P-0 \\
A_{00} \\
A_{0} \\
A_{11} \\
A_{12} \\
\text { AC } \\
C \\
\text { DSh } \\
\text { DSh } \\
\text { DSh } \\
\text { DSh } \\
\text { DSh } \\
\text { DSh } \\
\text { DSh } \\
\text { DSh } \\
\text { BR }\end{array}$ & $\begin{array}{l}* \\
* \\
* \\
4-2 \\
2-0 \\
0-7 \\
7-13 \\
13-19 \\
10-29 \\
29-36 \\
36-39 \\
39-42 \\
42-45 \\
45-48 \\
48-53 \\
53-58 \\
58-61 \\
>61\end{array}$ & $\begin{array}{r}2 \\
1 \\
5 \\
3 \\
26 \\
22 \\
10 \\
10 \\
10 \\
10 \\
60 \\
100 \\
70 \\
20 \\
120 \\
40 \\
80 \\
100 \\
150\end{array}$ & $\begin{array}{r}36 \\
15 \\
34 \\
50 \\
390 \\
360 \\
500 \\
475 \\
300 \\
200 \\
700 \\
1,400 \\
700 \\
700 \\
500 \\
500 \\
300 \\
700 \\
500\end{array}$ & $\begin{array}{r}60 \\
39 \\
70 \\
68 \\
>99 \\
60 \\
50 \\
75 \\
100 \\
75 \\
200 \\
350 \\
350 \\
350 \\
350 \\
350 \\
350 \\
350 \\
750\end{array}$ & $\begin{array}{r}20-50 \\
20-50 \\
50-100 \\
50-100 \\
225 \\
150 \\
150 \\
150 \\
150 \\
100 \\
750 \\
1,000 \\
1,000 \\
500 \\
1,000 \\
500 \\
1,000 \\
1,000 \\
2,000\end{array}$ & $\begin{array}{r}200-500 \\
200-500 \\
200-500 \\
200-500 \\
320 \\
740 \\
200 \\
350 \\
200 \\
200 \\
50 \\
200 \\
100 \\
500 \\
100 \\
50 \\
20 \\
50 \\
20\end{array}$ & \begin{tabular}{|r|}
$100-200$ \\
$50-100$ \\
$50-100$ \\
$20-50$ \\
45 \\
35 \\
5 \\
20 \\
20 \\
10 \\
50 \\
100 \\
50 \\
100 \\
50 \\
75 \\
35 \\
75 \\
100
\end{tabular} & \begin{tabular}{r}
750 \\
2,000 \\
1,500 \\
1,500 \\
\hdashline-2. \\
\hdashline 350 \\
500 \\
350 \\
200 \\
350 \\
500 \\
500 \\
500 \\
750 \\
350 \\
350 \\
200 \\
750
\end{tabular} & \begin{tabular}{r}
150 \\
350 \\
150 \\
350 \\
---- \\
\hdashline 750 \\
750 \\
750 \\
750 \\
150 \\
150 \\
200 \\
350 \\
200 \\
350 \\
150 \\
150 \\
350
\end{tabular} & $\begin{array}{r}1.0-2.0 \\
1.0-2.0 \\
2.0-4.0 \\
.5-1.0 \\
1.36 \\
.74 \\
.5 \\
.4 \\
.5 \\
.2 \\
6.0 \\
5.0 \\
3.0 \\
1.0 \\
5.0 \\
.6 \\
4.0 \\
3.0 \\
3.75\end{array}$ \\
\hline
\end{tabular}


TABLE 3.-Phosphorus and minor-element content of samples of 22 completc profiles and one bedrock exposure near Montpelier, Idaho-Continued

\begin{tabular}{|c|c|c|c|c|c|c|c|c|c|c|c|c|}
\hline \multicolumn{4}{|c|}{ Sample } & \multicolumn{9}{|c|}{ Constituent } \\
\hline $\begin{array}{l}\text { Lab. } \\
\text { No. }\end{array}$ & $\begin{array}{c}\text { Field } \\
\text { No. }\end{array}$ & Type & $\begin{array}{c}\text { Depth } \\
\text { (Inches) }\end{array}$ & $\mathrm{Cu}$ & $\mathbf{Z n}$ & v & $\mathrm{Cr}$ & Mn & Ni & $\mathrm{Sr}$ & $\mathbf{B a}$ & $\mathbf{P}$ \\
\hline \multicolumn{13}{|c|}{$\begin{array}{l}\text { PROFILES ABOVE PHOSPHORIA FORMATION-Continued } \\
\text { Profile at site } 13\end{array}$} \\
\hline 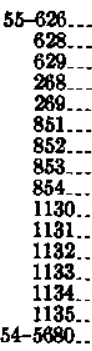 & $\begin{array}{l}106 \\
108 \\
109 \\
386 \\
387 \\
388 \\
389 \\
390 \\
391 \\
392 \\
393 \\
394 \\
395 \\
396 \\
397 \\
109\end{array}$ & $\begin{array}{l}\text { S-Y } \\
\text { P-Y } \\
\text { P-O } \\
A_{\infty 0} \\
A_{0} \\
A_{11} \\
A_{12} \\
\text { AC } \\
\text { C } \\
\text { DSh } \\
\text { DSh } \\
\text { DSh } \\
\text { DSh } \\
\text { DSh } \\
\text { DSh } \\
\text { BR }\end{array}$ & $\begin{array}{c}* \\
* \\
* \\
3-1 \\
1-0 \\
0-7 \\
7-14 \\
14-20 \\
20-32 \\
32-41 \\
41-44 \\
44-47 \\
47-49 \\
49-52 \\
52-61 \\
>61\end{array}$ & $\begin{array}{r}3 \\
5 \\
22 \\
23 \\
15 \\
15 \\
8 \\
10 \\
80 \\
80 \\
80 \\
30 \\
120 \\
80 \\
100\end{array}$ & \begin{tabular}{r}
15 \\
\hdashline 56 \\
380 \\
400 \\
600 \\
525 \\
225 \\
125 \\
500 \\
1,000 \\
1,200 \\
700 \\
500 \\
800 \\
400
\end{tabular} & $\begin{array}{r}31 \\
50 \\
64 \\
>70 \\
56 \\
100 \\
100 \\
75 \\
100 \\
1,000 \\
200 \\
200 \\
200 \\
750 \\
350 \\
500\end{array}$ & $\begin{array}{r}10-20 \\
50-100 \\
50-100 \\
160 \\
170 \\
350 \\
350 \\
100 \\
150 \\
750 \\
750 \\
750 \\
350 \\
2,000 \\
1,000 \\
750\end{array}$ & $\begin{array}{r}200-500 \\
500-1,000 \\
200-500 \\
480 \\
850 \\
350 \\
350 \\
350 \\
350 \\
75 \\
50 \\
200 \\
500 \\
200 \\
75 \\
15\end{array}$ & $\begin{array}{r}20-50 \\
20-50 \\
20-50 \\
32 \\
40 \\
20 \\
35 \\
10 \\
20 \\
50 \\
60 \\
150 \\
100 \\
50 \\
75 \\
75\end{array}$ & \begin{tabular}{l}
1,000 \\
1,500 \\
2,000 \\
$-\cdots--$ \\
\hdashline 500 \\
350 \\
200 \\
200 \\
500 \\
350 \\
350 \\
500 \\
750 \\
500 \\
750
\end{tabular} & $\begin{array}{r}75 \\
200 \\
350 \\
- \\
750 \\
750 \\
500 \\
750 \\
150 \\
200 \\
200 \\
350 \\
200 \\
500 \\
500\end{array}$ & $\begin{array}{r}1.0-2.0 \\
1.0-2.0 \\
0.5-1.0 \\
1.0 \\
.8 \\
1.0 \\
.8 \\
.3 \\
.2 \\
9.0 \\
4.0 \\
2.0 \\
2.0 \\
6.0 \\
1.0 \\
.60\end{array}$ \\
\hline
\end{tabular}

Profle at site 14

\begin{tabular}{|c|c|c|c|c|c|c|c|c|c|c|c|c|}
\hline 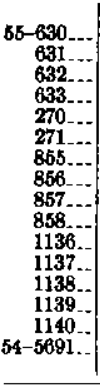 & $\begin{array}{l}110 \\
111 \\
112 \\
113 \\
398 \\
399 \\
400 \\
401 \\
402 \\
403 \\
404 \\
405 \\
406 \\
407 \\
408 \\
210\end{array}$ & 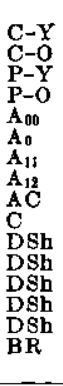 & $\begin{array}{c}* \\
* \\
4-2.5 \\
2.5-0 \\
0-6 \\
6-12 \\
12-16 \\
16-24 \\
24-34 \\
34-42 \\
42-51 \\
51-54 \\
54-59 \\
>59\end{array}$ & $\begin{array}{r}1 \\
<1 \\
3 \\
24 \\
19 \\
15 \\
75 \\
20 \\
22 \\
40 \\
60 \\
60 \\
30 \\
160 \\
150\end{array}$ & $\begin{array}{r}24 \\
11 \\
-70 \\
290 \\
180 \\
550 \\
600 \\
525 \\
550 \\
700 \\
700 \\
1,000 \\
800 \\
700 \\
750\end{array}$ & $\begin{array}{r}26 \\
26 \\
46 \\
81 \\
>100 \\
29 \\
200 \\
500 \\
350 \\
350 \\
350 \\
200 \\
350 \\
500 \\
500 \\
750\end{array}$ & $\begin{array}{r}20-50 \\
20-50 \\
50-100 \\
50-100 \\
230 \\
120 \\
350 \\
1,000 \\
350 \\
350 \\
750 \\
500 \\
750 \\
750 \\
1,500 \\
1,500\end{array}$ & $\begin{array}{r}500-1,000 \\
200-500 \\
500-1,000 \\
500-1,000 \\
320 \\
585 \\
500 \\
50 \\
350 \\
350 \\
200 \\
200 \\
100 \\
500 \\
50 \\
100\end{array}$ & $\mid \begin{array}{r}50-100 \\
20-50 \\
20-50 \\
20-50 \\
46 \\
39 \\
20 \\
100 \\
20 \\
20 \\
50 \\
50 \\
75 \\
150 \\
75 \\
150\end{array}$ & \begin{tabular}{|r}
1,500 \\
3,500 \\
1,500 \\
2,000 \\
\hdashline$-\cdots$ \\
$\cdots 350$ \\
1,000 \\
350 \\
350 \\
500 \\
350 \\
500 \\
350 \\
750 \\
3,500
\end{tabular} & \begin{tabular}{|c|}
150 \\
500 \\
350 \\
500 \\
\hdashline-2 \\
500 \\
200 \\
750 \\
500 \\
350 \\
350 \\
500 \\
350 \\
150 \\
150
\end{tabular} & $\begin{array}{r}1.0-2.0 \\
0.5-1.0 \\
2.0-5.0 \\
1.0-2.0 \\
1.4 \\
.6 \\
1.0 \\
5.0 \\
2.0 \\
2.0 \\
3.0 \\
2.0 \\
1.0 \\
.6 \\
6.0 \\
7.50\end{array}$ \\
\hline
\end{tabular}

Profile at site 15

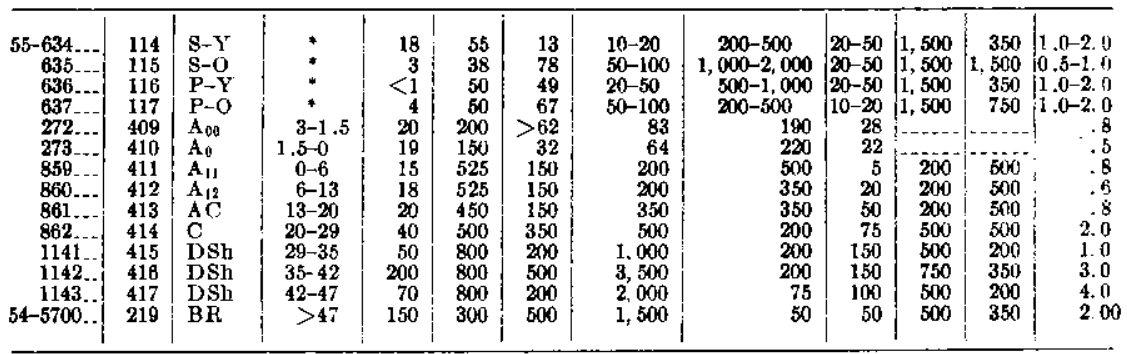


TABLE 3.-Phosphorus and minor-element content of samples of 22 complete profiles and one bedrock exposure near Montpelier, Idaho-Continued

\begin{tabular}{|c|c|c|c|c|c|c|c|c|c|c|c|c|}
\hline \multicolumn{4}{|c|}{ Sample } & \multicolumn{9}{|c|}{ Constituent } \\
\hline $\begin{array}{l}\text { Lab. } \\
\text { No. }\end{array}$ & $\begin{array}{c}\text { Field } \\
\text { No. }\end{array}$ & Type & $\begin{array}{c}\text { Depth } \\
\text { (inches) }\end{array}$ & $\mathrm{Cu}$ & $\mathrm{zn}_{\mathrm{n}}$ & $v$ & $\mathrm{Cr}$ & Mn & $\mathrm{Ni}$ & Sr & $\mathrm{Ba}$ & $\mathbf{P}$ \\
\hline
\end{tabular}

PROFILES ABOVE PHOSPHORIA FORMATION-Continded

Profile at site 16

\begin{tabular}{|c|c|c|c|c|c|c|c|c|c|c|c|c|}
\hline $\begin{array}{r}55-638 \\
639 . \\
274 \\
275 \\
863 .- \\
864- \\
865 .- \\
866 \\
1144 \\
1145 \\
1146 \\
1147 . \\
1148 . \\
1149 . \\
54-5707 .-\end{array}$ & $\begin{array}{l}118 \\
119 \\
418 \\
419 \\
420 \\
421 \\
422 \\
423 \\
424 \\
425 \\
426 \\
427 \\
428 \\
429 \\
226\end{array}$ & $\begin{array}{l}\text { S-Y } \\
\text { S-O } \\
A_{00} \\
A_{0} \\
A_{11} \\
A_{12} \\
A C \\
C \\
\text { DSh } \\
\text { DSh } \\
\text { DSh } \\
\text { DSb } \\
\text { DSh } \\
\text { DSh } \\
\text { BR }\end{array}$ & $\begin{array}{c}* \\
* \\
3.5-2.5 \\
2.5-0 \\
0-6 \\
6-12 \\
12-16 \\
16-25 \\
25-30 \\
30-38 \\
38-45 \\
45-53 \\
53-58 \\
58-64 \\
>64\end{array}$ & $\begin{array}{r}6 \\
2 \\
22 \\
17 \\
12 \\
10 \\
10 \\
12 \\
30 \\
70 \\
120 \\
60 \\
60 \\
200 \\
100\end{array}$ & $\begin{array}{r}42 \\
36 \\
300 \\
320 \\
500 \\
425 \\
425 \\
300 \\
500 \\
800 \\
800 \\
1,200 \\
1,600 \\
2,000 \\
2,500\end{array}$ & $\begin{array}{r}21 \\
72 \\
>81 \\
77 \\
100 \\
200 \\
100 \\
200 \\
1,000 \\
750 \\
500 \\
350 \\
200 \\
200 \\
500\end{array}$ & $\begin{array}{r}10-20 \\
50-100 \\
185 \\
64 \\
75 \\
100 \\
75 \\
75 \\
500 \\
1,000 \\
1,500 \\
1,000 \\
750 \\
1,000 \\
1,500\end{array}$ & $\begin{array}{r}200-500 \\
500-1,000 \\
260 \\
450 \\
350 \\
350 \\
350 \\
200 \\
200 \\
100 \\
50 \\
100 \\
500 \\
500 \\
500\end{array}$ & $\begin{array}{r}20-50 \\
10-20 \\
55 \\
32 \\
5 \\
20 \\
35 \\
35 \\
50 \\
75 \\
75 \\
100 \\
100 \\
150 \\
350\end{array}$ & \begin{tabular}{|c|}
1,500 \\
1,500 \\
$-\cdots 200$ \\
-200 \\
150 \\
200 \\
500 \\
500 \\
750 \\
500 \\
350 \\
750 \\
750
\end{tabular} & \begin{tabular}{|c}
350 \\
1,500 \\
$-\cdots--$ \\
\hdashline 500 \\
750 \\
500 \\
500 \\
500 \\
200 \\
200 \\
350 \\
150 \\
200 \\
350
\end{tabular} & $\begin{array}{r}1.0-2.0 \\
1.0-2.0 \\
1.0 \\
1.0 \\
.6 \\
.5 \\
.4 \\
.4 \\
5.0 \\
6.0 \\
6.0 \\
2.0 \\
2.0 \\
8.0 \\
2.00\end{array}$ \\
\hline
\end{tabular}

Profile at site 17

\begin{tabular}{|c|c|c|c|c|c|c|c|c|c|c|c|c|}
\hline 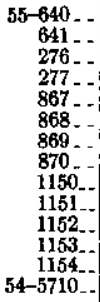 & $\begin{array}{l}120 \\
121 \\
430 \\
431 \\
432 \\
433 \\
434 \\
435 \\
436 \\
437 \\
438 \\
439 \\
440 \\
229\end{array}$ & 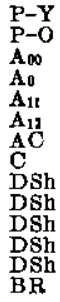 & $\begin{array}{c}* \\
* \\
3-1.5 \\
1.5-0 \\
0-6 \\
6-12 \\
12-16 \\
16-31 \\
31-41 \\
41-46 \\
46-50 \\
50-55 \\
55-61 \\
>61\end{array}$ & $\begin{array}{r}2 \\
17 \\
20 \\
10 \\
8 \\
10 \\
8 \\
70 \\
200 \\
70 \\
50 \\
80 \\
75\end{array}$ & $\begin{array}{r}40 \\
50 \\
120 \\
210 \\
400 \\
400 \\
275 \\
425 \\
1,400 \\
800 \\
800 \\
1,000 \\
1,200 \\
750\end{array}$ & $\begin{array}{r}27 \\
72 \\
>62 \\
45 \\
200 \\
200 \\
150 \\
150 \\
1,500 \\
1,000 \\
350 \\
350 \\
1,000 \\
150\end{array}$ & $\begin{array}{r}10-20 \\
50-100 \\
105 \\
62 \\
75 \\
75 \\
50 \\
75 \\
1,000 \\
1,500 \\
1,000 \\
1,000 \\
1,000 \\
350\end{array}$ & $\begin{array}{r}500-1,000 \\
200-500 \\
150 \\
620 \\
75 \\
500 \\
350 \\
350 \\
75 \\
20 \\
20 \\
50 \\
50 \\
100\end{array}$ & $\begin{array}{r}10-20 \\
20-50 \\
21 \\
30 \\
8 \\
10 \\
10 \\
5 \\
15 \\
75 \\
50 \\
50 \\
75 \\
150 \\
100\end{array}$ & \begin{tabular}{r}
1,000 \\
3,500 \\
\hdashline-150 \\
\hdashline 200 \\
150 \\
100 \\
500 \\
750 \\
500 \\
500 \\
350 \\
150
\end{tabular} & $\begin{array}{r}200 \\
750 \\
-200 \\
500 \\
500 \\
150 \\
150 \\
150 \\
150 \\
200 \\
200 \\
50\end{array}$ & $\begin{array}{r}1.0-2.0 \\
0.5-1.0 \\
.6 \\
.6 \\
1.0 \\
.5 \\
.3 \\
.5 \\
8.0 \\
5.0 \\
6.0 \\
2.0 \\
1.0 \\
.25\end{array}$ \\
\hline
\end{tabular}

Profle at site 18

\begin{tabular}{|c|c|c|c|c|c|c|c|c|c|c|c|c|}
\hline $\begin{array}{r}55-642 .- \\
643- \\
278 \ldots \\
279 \ldots \\
871- \\
872- \\
873- \\
874- \\
1155 .- \\
1156 .- \\
1157 .- \\
1158 .- \\
1159 .- \\
1160 \ldots \\
54-5717 .\end{array}$ & $\begin{array}{l}122 \\
123 \\
441 \\
442 \\
443 \\
444 \\
445 \\
446 \\
447 \\
448 \\
449 \\
450 \\
451 \\
452 \\
236\end{array}$ & $\begin{array}{l}\text { S-Y } \\
\text { S-O } \\
A_{00} \\
A_{0} \\
A_{11} \\
A_{12} \\
A_{C} \\
\text { C } \\
\text { DSh } \\
\text { DSh } \\
\text { DSh } \\
\text { DSh } \\
\text { DSh } \\
\text { DSh } \\
\text { BR }\end{array}$ & $\begin{array}{c}* \\
3-1.5 \\
1.5-0 \\
0-7 \\
7-13 \\
13-18 \\
18-35 \\
35-44 \\
44-50 \\
50-54 \\
54-60 \\
60-64 \\
64-69 \\
>69\end{array}$ & $\begin{array}{r}3 \\
9 \\
14 \\
8 \\
10 \\
10 \\
10 \\
60 \\
80 \\
200 \\
70 \\
60 \\
70 \\
100\end{array}$ & $\begin{array}{r}32 \\
38 \\
110 \\
120 \\
375 \\
300 \\
250 \\
550 \\
1,200 \\
1,000 \\
500 \\
700 \\
700 \\
700 \\
400\end{array}$ & $\begin{array}{r}11 \\
99 \\
>35 \\
28 \\
100 \\
100 \\
100 \\
200 \\
2,000 \\
1,500 \\
1,000 \\
500 \\
350 \\
200 \\
350\end{array}$ & $\begin{array}{r}\text { Trace } \\
50-110 \\
80 \\
42 \\
35 \\
35 \\
75 \\
75 \\
750 \\
1,000 \\
1,500 \\
500 \\
1,000 \\
1,000 \\
750\end{array}$ & $\begin{array}{r}200-500 \\
1,000-2,000 \\
100 \\
200 \\
350 \\
200 \\
200 \\
150 \\
150 \\
100 \\
20 \\
35 \\
75 \\
35 \\
10\end{array}$ & $\begin{array}{r}10-20 \\
20-50 \\
16 \\
20 \\
<5 \\
<5 \\
10 \\
20 \\
75 \\
100 \\
35 \\
35 \\
75 \\
35 \\
75\end{array}$ & $\mid$\begin{tabular}{r}
1,000 \\
1,500 \\
\hdashline-200 \\
\hdashline 50 \\
150 \\
100 \\
500 \\
350 \\
750 \\
750 \\
500 \\
500 \\
350
\end{tabular} & \begin{tabular}{|c|}
350 \\
1,500 \\
\hdashline-200 \\
-500 \\
500 \\
200 \\
100 \\
100 \\
100 \\
200 \\
200 \\
200 \\
500
\end{tabular} & $\begin{array}{r}1.0-2.0 \\
1.0-2.0 \\
.5 \\
.4 \\
.5 \\
.5 \\
.4 \\
1.5 \\
6.0 \\
6.0 \\
6.0 \\
4.0 \\
3.0 \\
3.0 \\
.75\end{array}$ \\
\hline
\end{tabular}


TABLE 3.-Phosphorus and minor-element content of samples of 22 complete profiles and one bedrock exposure near Montpelier, Idaho-Continued

\begin{tabular}{l|c|c|c|c|c|c|c|c|c|c|c|c}
\hline \multicolumn{3}{c|}{ Sample } & \multicolumn{10}{c}{ Constituent } \\
\hline $\begin{array}{c}\text { Lab. } \\
\text { No. }\end{array}$ & $\begin{array}{c}\text { Fteld } \\
\text { No. }\end{array}$ & Type & $\begin{array}{c}\text { Depth } \\
\text { (inches) }\end{array}$ & Cu & Zn & V & Cr & Mn & N1 & Sr & Ba & P \\
\hline
\end{tabular}

PROFILES ABOVE PHOSPHORIA FORMATION-Continued

Profile at aite 19

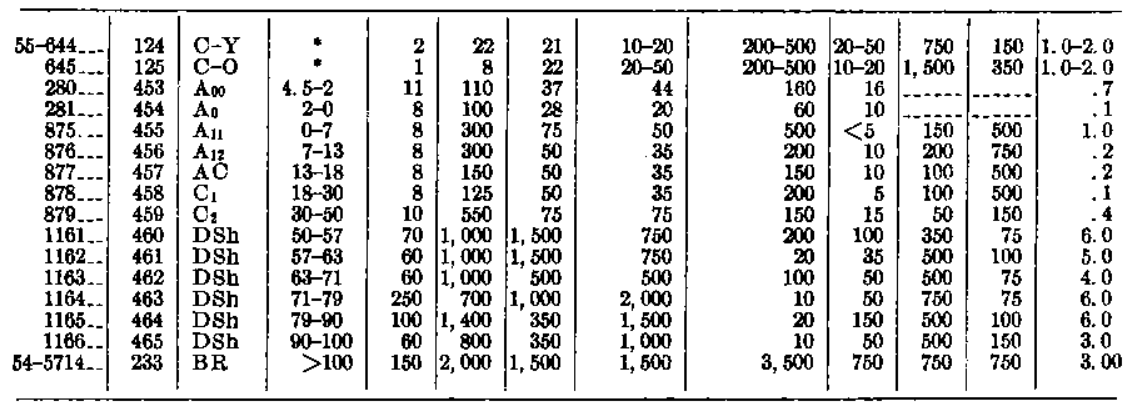

Proflle at site 20

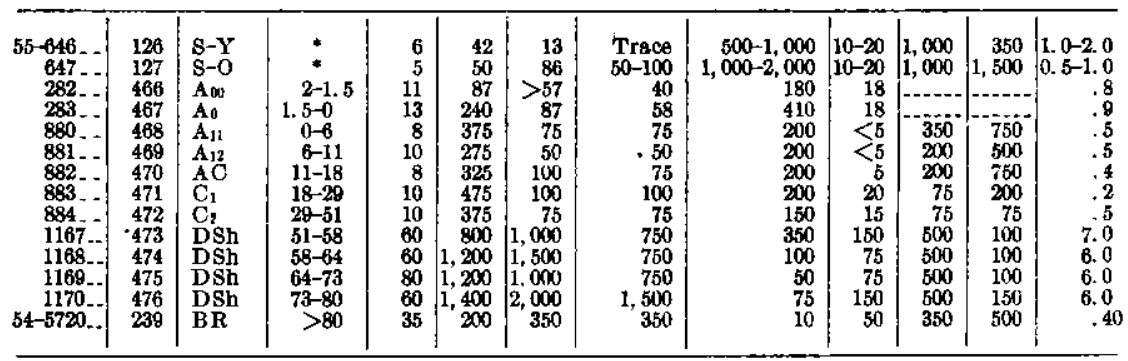

Profile at site 21

\begin{tabular}{|c|c|c|c|c|c|c|c|c|c|c|c|c|}
\hline $\begin{array}{r}55-648 \\
649 . \\
284 \\
285 \\
885 \\
886 .- \\
887 \\
888 \\
1171 \ldots \\
1172 . \\
1173 . \\
1174 \\
1175 . \\
54-5736 \\
\end{array}$ & $\begin{array}{l}128 \\
129 \\
477 \\
478 \\
479 \\
480 \\
481 \\
482 \\
483 \\
484 \\
485 \\
486 \\
487 \\
255\end{array}$ & $\begin{array}{l}P-Y \\
P-0 \\
A_{00} \\
A_{0} \\
A_{11} \\
A_{12} \\
C_{1} \\
C_{2} \\
\text { DSh } \\
\text { DSh } \\
\text { DSh } \\
\text { DSb } \\
\text { DSh } \\
\text { BR }\end{array}$ & $\begin{array}{l}* \\
* \\
3-1 \\
1-0 \\
0-6 \\
6-12 \\
12-23 \\
23-43 \\
43-49 \\
49-56 \\
56-63 \\
63-68 \\
68-74 \\
>74\end{array}$ & $\begin{array}{r}4 \\
4 \\
13 \\
16 \\
10 \\
10 \\
10 \\
12 \\
60 \\
60 \\
100 \\
70 \\
80 \\
100\end{array}$ & $\begin{array}{r}30 \\
50 \\
160 \\
140 \\
325 \\
350 \\
150 \\
600 \\
800 \\
800 \\
1,400 \\
1,200 \\
1,400 \\
750\end{array}$ & $\begin{array}{r}18 \\
42 \\
>62 \\
72 \\
100 \\
100 \\
75 \\
75 \\
2,000 \\
750 \\
1,500 \\
1,500 \\
2,000 \\
1,000\end{array}$ & $\begin{array}{r}20-50 \\
20-50 \\
56 \\
40 \\
150 \\
100 \\
100 \\
150 \\
1,000 \\
1,500 \\
1,000 \\
1,000 \\
500 \\
750\end{array}$ & $\begin{array}{r}200-500 \\
500-1,000 \\
190 \\
280 \\
350 \\
200 \\
200 \\
200 \\
750 \\
750 \\
100 \\
35 \\
50 \\
15\end{array}$ & $\begin{array}{r}10-20 \\
10-20 \\
19 \\
20 \\
5 \\
5 \\
20 \\
20 \\
100 \\
150 \\
100 \\
75 \\
20 \\
50\end{array}$ & $\begin{array}{r}1.000 \\
1,500 \\
-350 \\
150 \\
100 \\
50 \\
750 \\
750 \\
500 \\
750 \\
500 \\
500\end{array}$ & $\begin{array}{r}350 \\
750 \\
750 \\
350 \\
500 \\
100 \\
150 \\
150 \\
150 \\
150 \\
100 \\
75\end{array}$ & $\begin{array}{r}2.0-5.0 \\
1.0-2.0 \\
.8 \\
.6 \\
1.0 \\
1.0 \\
.2 \\
.4 \\
16.0 \\
6.0 \\
6.0 \\
6.0 \\
7.0 \\
7.50\end{array}$ \\
\hline
\end{tabular}

Profile at site 22

\begin{tabular}{|c|c|c|c|c|c|c|c|c|c|c|c|c|}
\hline 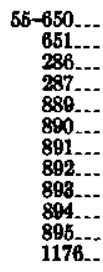 & $\begin{array}{l}130 \\
131 \\
496 \\
497 \\
488 \\
489 \\
490 \\
491 \\
492 \\
493 \\
494 \\
495\end{array}$ & $\begin{array}{l}8-Y \\
\text { S-O } \\
A_{00} \\
A_{0} \\
A_{11} \\
A_{12} \\
C_{1} \\
C_{1} \\
C_{2} \\
C_{2} \\
C_{4} \\
B-R\end{array}$ & $\begin{array}{c}* \\
* \\
1-0.5 \\
0.5-0 \\
0-5 \\
6-10 \\
10-16 \\
16-26 \\
26-37 \\
37-56 \\
66-74 \\
>84\end{array}$ & $\begin{array}{r}<1 \\
4 \\
13 \\
14 \\
15 \\
10 \\
8 \\
8 \\
8 \\
10 \\
26 \\
70\end{array}$ & \begin{tabular}{|r}
24 \\
48 \\
140 \\
240 \\
300 \\
260 \\
325 \\
375 \\
276 \\
675 \\
1,300 \\
800
\end{tabular} & \begin{tabular}{|r}
$<10$ \\
59 \\
28 \\
45 \\
75 \\
50 \\
50 \\
50 \\
75 \\
100 \\
100 \\
2,000
\end{tabular} & $\begin{array}{r}20-50 \\
19 \\
40 \\
100 \\
75 \\
75 \\
50 \\
100 \\
200 \\
350 \\
500\end{array}$ & $\begin{array}{r}200-500 \\
5,000-10,000 \\
280 \\
400 \\
350 \\
350 \\
350 \\
3350 \\
500 \\
1500 \\
150 \\
20\end{array}$ & $\begin{array}{r}5-10 \\
10-20 \\
13 \\
31 \\
15 \\
10 \\
<5 \\
5 \\
10 \\
20 \\
50 \\
20\end{array}$ & $\begin{array}{r}200 \\
200 \\
150 \\
150 \\
150 \\
50 \\
75 \\
750\end{array}$ & $\begin{array}{r}350 \\
350 \\
200 \\
200 \\
350 \\
150 \\
150 \\
75\end{array}$ & $\begin{array}{r}1.0-2.0 \\
1.0-2.0 \\
.3 \\
.4 \\
.2 \\
.3 \\
.2 \\
.3 \\
.2 \\
2.0 \\
1.5 \\
18.0\end{array}$ \\
\hline
\end{tabular}


TABLE 3-Phosphorus and minor-element content of samples of 22 complete profiles and one bedrock erposure near Hontpelier, Idaho-Continued

\begin{tabular}{|c|c|c|c|c|c|c|c|c|c|c|c|c|}
\hline \multicolumn{4}{|c|}{ Sample } & \multicolumn{9}{|c|}{ Constituent } \\
\hline $\begin{array}{l}\text { Lab. } \\
\text { No. }\end{array}$ & $\begin{array}{l}\text { Field } \\
\text { No. }\end{array}$ & Type & $\begin{array}{c}\text { Depth } \\
\text { (inches) }\end{array}$ & $\mathrm{Cu}$ & $\mathrm{Zn}$ & $\mathrm{V}$ & $\mathrm{Cr}$ & Mn & Ni & $\mathrm{Sr}$ & $\mathrm{Ba}$ & $\mathbf{P}$ \\
\hline
\end{tabular}

PROFILES ABOVE PARK CITY FORMATION

Profile at site 23

\begin{tabular}{|c|c|c|c|c|c|c|c|c|c|c|c|c|}
\hline $\begin{array}{r}55-652 \\
653 \\
288 .- \\
289 \\
896 \ldots- \\
897 \ldots \\
898 \ldots \\
899 \\
900 \ldots \\
901\end{array}$ & $\begin{array}{l}132 \\
133 \\
498 \\
499 \\
500 \\
501 \\
502 \\
503 \\
504 \\
505\end{array}$ & $\begin{array}{l}S-Y \\
\text { S-O } \\
A_{00} \\
A_{0} \\
A_{1} \\
A_{C} \\
C_{1} \\
C_{2} \\
C_{3} \\
C_{1}\end{array}$ & $\begin{array}{l}* \\
* \\
4-3 \\
3-0 \\
0-8 \\
8-15 \\
15-25 \\
25-38 \\
38-55 \\
55-69\end{array}$ & $\begin{array}{r}5 \\
4 \\
12 \\
19 \\
10 \\
10 \\
8 \\
8 \\
8 \\
10\end{array}$ & $\begin{array}{r}20 \\
24 \\
75 \\
110 \\
300 \\
300 \\
250 \\
325 \\
300 \\
850\end{array}$ & $\begin{array}{r}<10 \\
39 \\
5 \\
16 \\
50 \\
100 \\
50 \\
75 \\
75 \\
50\end{array}$ & $\begin{array}{r}20-50 \\
20-50 \\
8 \\
16 \\
75 \\
150 \\
75 \\
150 \\
100 \\
350\end{array}$ & $\begin{array}{r}200-500 \\
5,000-10,000 \\
180 \\
350 \\
350 \\
350 \\
350 \\
200 \\
150 \\
100\end{array}$ & $\begin{array}{r}10-20 \\
10-20 \\
4 \\
12 \\
<5 \\
50 \\
5 \\
35 \\
<5 \\
50\end{array}$ & \begin{tabular}{r}
750 \\
1,500 \\
\hdashline$-\cdots$ \\
\hdashline 350 \\
200 \\
200 \\
100 \\
150 \\
100
\end{tabular} & \begin{tabular}{r}
200 \\
1,500 \\
\hdashline 750 \\
500 \\
500 \\
200 \\
150 \\
200
\end{tabular} & $\begin{array}{r}1.0-2.0 \\
1.0-2.0 \\
.1 \\
.2 \\
.2 \\
.3 \\
.2 \\
.5 \\
.5 \\
1.0\end{array}$ \\
\hline
\end{tabular}

Profile at site 24

\begin{tabular}{|c|c|c|c|c|c|c|c|c|c|c|c|c|}
\hline 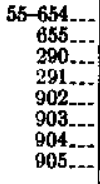 & $\begin{array}{l}134 \\
135 \\
506 \\
507 \\
508 \\
509 \\
510 \\
511\end{array}$ & $\begin{array}{l}\text { B-Y } \\
\text { S-O } \\
A_{00} \\
A_{0} \\
A_{1} \\
A_{C} \\
\mathbf{C}_{1} \\
\mathbf{C}_{2}\end{array}$ & $\begin{array}{c}* \\
* \\
4-3 \\
3-0 \\
0-8 \\
8-15 \\
15-25 \\
25-40\end{array}$ & $\begin{array}{r}6 \\
2 \\
13 \\
13 \\
8 \\
10 \\
10 \\
8\end{array}$ & $\begin{array}{r}24 \\
38 \\
65 \\
85 \\
300 \\
300 \\
300 \\
375\end{array}$ & $\begin{array}{r}<10 \\
29 \\
10 \\
19 \\
35 \\
75 \\
50 \\
100\end{array}$ & $\begin{array}{r}10-20 \\
20-50 \\
10 \\
14 \\
35 \\
75 \\
50 \\
100\end{array}$ & $\begin{array}{r}200-500 \\
2,000-5,000 \\
320 \\
200 \\
200 \\
350 \\
350 \\
200\end{array}$ & $\begin{array}{r}10-20 \\
10-20 \\
6 \\
8 \\
<5 \\
10 \\
10 \\
15\end{array}$ & \begin{tabular}{r}
750 \\
750 \\
-2 \\
\hdashline 100 \\
75 \\
100 \\
75
\end{tabular} & \begin{tabular}{r}
350 \\
1,500 \\
\hdashline- \\
-500 \\
500 \\
500 \\
200
\end{tabular} & $\left\{\begin{array}{r}1.0-2.0 \\
1.0-2.0 \\
.2 \\
.1 \\
.1 \\
.1 \\
.1 \\
.3\end{array}\right.$ \\
\hline
\end{tabular}

Profile at site 27

\begin{tabular}{|c|c|c|c|c|c|c|c|c|c|c|c|c|}
\hline $\begin{array}{r}55-769 .- \\
728 .- \\
3973 .- \\
3974 .- \\
3975-- \\
3976-- \\
3977 .- \\
3978-- \\
3979 .-\end{array}$ & $\begin{array}{l}569 \\
570 \\
729 \\
730 \\
731 \\
732 \\
733 \\
734 \\
735\end{array}$ & $\begin{array}{l}P \\
C \\
A_{100} \\
A_{1} \\
A_{C} \\
C_{1} \\
C_{2} \\
C_{2} \\
C_{1}\end{array}$ & $\begin{array}{c}* \\
* \\
3-0 \\
0-6 \\
6-15 \\
15-23 \\
23-32 \\
32-43 \\
43-54\end{array}$ & $\begin{array}{r}6 \\
2 \\
18 \\
14 \\
9 \\
10 \\
16 \\
15 \\
10\end{array}$ & $\begin{array}{r}40 \\
4 \\
100 \\
140 \\
100 \\
140 \\
120 \\
150 \\
300\end{array}$ & $\begin{array}{r}\mathbf{3 2} \\
23 \\
35 \\
75 \\
50 \\
50 \\
50 \\
35 \\
100\end{array}$ & $\begin{array}{r}20-50 \\
10-20 \\
5 \\
35 \\
35 \\
35 \\
35 \\
35 \\
50\end{array}$ & $\begin{array}{r}500-1,000 \\
200-500 \\
350 \\
500 \\
75 \\
50 \\
50 \\
50 \\
350\end{array}$ & $\left\{\begin{array}{r}10-20 \\
5-10 \\
<5 \\
20 \\
10 \\
20 \\
20 \\
50 \\
75\end{array}\right.$ & $\begin{array}{r}1,500 \\
1,500 \\
200 \\
500 \\
150 \\
150 \\
50 \\
50 \\
50\end{array}$ & $\begin{array}{l}750 \\
500 \\
350 \\
750 \\
500 \\
500 \\
350 \\
200 \\
150\end{array}$ & $\begin{array}{r}0.5-1.0 \\
0.5-1.0 \\
\text { Tr. } \\
.01 \\
.025 \\
.025 \\
.005 \\
.005 \\
.025\end{array}$ \\
\hline
\end{tabular}

BEDROCK FROM EXPOSED PARK CITY FORMATION

\begin{tabular}{l|l|l|l|l|l|l|l|l|l|l|l|l}
\hline $61-4101$ & 785 & BR & 0 & 10 & 350 & 100 & 70 & 50 & 20 & 100 & 10 & 0.45 \\
\hline
\end{tabular}

\section{COLLUVIALLY DRAGGED LA YERS OF SHALE}

Methods used for analyzing samples from layers of colluvially dragged shale are the same as those used for analysis of samples of shale in place. An individual layer of the dragged shale could commonly be identified with the bed from which it was mainly derived, although some samples contained rock fragments from as many as three beds.

Layers of bedrock having a high vanadium content retain a high concentration of vanadium as dragged layers, except when there has been significant dilution with material of low vanadium content. 
Dragged layers containing abundant chromium are derived from shale beds that are high in chromium, but the chromium concentration in some dragged layers that can be traced are greater than the contents of equivalent bedrock in place. For example, two samples from site 15 that contain 3,500 and $2,000 \mathrm{ppm}$ chromium, respectively, are derived from beds containing 2,000 and $1,500 \mathrm{ppm}$ chromium.

Zinc is more evenly distributed through the dragged layers than the other elements and ranges from 500 to $2,000 \mathrm{ppm}$. In general, dragged layers contain less zinc than the beds from which they are derived. Nonetheless the dragged layers that contain the most zine are derived from the shale beds of highest zinc content.

Strontium in dragged layers is less than that in the source beds. In a single sample of the dragged shale, this element has a value of 1,000 ppm; otherwise, its range is from 100 to $750 \mathrm{ppm}$. In bedrock, strontium content is as high as $3,500 \mathrm{ppm}$.

The maximum barium content in dragged layers is $500 \mathrm{ppm}$, which is the content of four samples, whereas the maximum in bedrock samples is $750 \mathrm{ppm}$. The decrease in the barium content of dragged layers-perceptible, but not so pronounced as that of strontiumindicates that barium compounds are commonly less soluble than those of strontium. Dragged layers high in barium, however, are derived from layers of bedrock that are high in barium.

The relation of phosphorus content of bedrock to that of dragged layers requires consideration of the data in table 2 as well as study of values in table 3 , which alone might be misleading. In table 3 , only one phosphorus value above 7.5 percent is shown for bedrock as compared to 17 values above 7.5 percent phosphorus in the dragged layers. Actually the phosphorus content of the dragged layers is lower than that of their respective beds in place, when analyses of equivalent beds are compared.

Thin beds relatively rich in copper retain their copper content as dragged layers for tens of feet downhill. Sample 463, which was taken at site 19 from a layer 30 to 40 feet downslope from the bed from which it was derived, contains $250 \mathrm{ppm}$ copper, the maximum among samples of dragged layers of shale. Vertical migration of copper seems to have been insignificant, because although dragged layers are only 4 to 6 inches thick, samples from material both above and bolow these dragged layers contain less copper. Although table 3) shows a maximum copper content of only $150 \mathrm{ppm}$ in the bedrock samples included, table 2 shows that the greatest concentration of copper is $500 \mathrm{ppm}$, found in one sample of weathered bedrock that is also high in organic matter (11 percent carbon) and rather high in phosphate. 
What happens to nickel during weathering is not clear. Several dragged layers derived from beds in the lower part of the shale section have a higher nickel content than that of beds in place, whereas others have a nickel content that is much lower than that of the beds in place.

Maximum manganese content in dragged layers is considerably less than that in bedrock. The two highest values for manganese in the dragged layers are 750 and $500 \mathrm{ppm}$ as compared to 3,500 and $1,000 \mathrm{ppm}$ in the bedrock.

\section{SOIL}

The $\mathrm{pH}$ of soil was determined on a soil-water paste of each sample by use of a Beckman $\mathrm{pH}$ meter having a glass electrode. Particle size distribution was estimated by the method of Kilmer and Alexander (1949). To obtain an estimate of the organic content of ench sample, a split from each was oven-dried and weighed. After the split was treated with 30 percent $\mathrm{H}_{2} \mathrm{O}_{2}$, it was weighed again. From the difference in the weights, the approximate weight of organic matter included in the sample was computed. Soil samples were prepared for analytical study by being air dried, disaggregated, and screened through a sieve having a 2 -mm mesh. No attempt was made to crush rock particles, and all material that stayed on the sieve was discarded.

The samples were analyzed for phosphorus by the chemical semiquantitative field method used in analysis of the shale samples. Vanadium content also was determined by use of a rapid chemical semiquantitative field method. Copper content of soil samples was determined by use of the biquinoline analytical method described by Almond (1955), and zinc content was determined by use of a modification of the dithizone analytical method described by Holmes (1945). The samples were analyzed semiquantitatively also by means of the truck-mounted spectrograph.

The $\mathrm{pH}$ ranges from 4.6 , in the $A$ horizon of profile 19 , to 7.7 , in the horizons of profile 23 . Free carbonates are not present. Overall acidity is greatest in the horizons that have the most organic matter, the $\mathrm{pH}$ ranging from 4.6 to 6.2 ; in the mineral soil the range is from 6.0 to 7.7 .

The relative amount and distribution of sand $(2-0.05 \mathrm{~mm})$, silt $(0.05-0.002 \mathrm{~mm})$, and clay $(<0.002 \mathrm{~mm})$ within a soil profile gives information on soil-forming processes and on the sources from which the soil is derived. The great amount of sand in all profiles studied (40-60 percent) is believed to indicate that the soil has been derived from the sandy Grandeur Tongue of the Park City Formation. 
The vertical distribution of clay is similar in all profiles. The general range in the clay content of the soils is from 10 to 15 percent, although the $\mathrm{C}$ horizon of profile 4 contains 20 percent, and a few profiles have horizons that contain only 7-8 percent of clay. Such small variations in clay content within the profiles suggest that there has been little or no eluviation of clay by soil-forming processes and that the variations observed may be ascribed to mixing during colluvial movement of the parent material of the soil.

Organic matter is most abundant in horizons near the surface; in the soils studied, the organic content decreases rapidly with depth. Samples from profile 1 contain the most organic matter-as much as 4.3 percent at the surface; samples from all other profiles average from 1.5 to 2 percent.

The generalized description in table 1 is representative, with minor variations, of all the soil profiles examined. Thicknesses of soil in individual profiles range from 12 to 74 inches. The $\mathrm{C}$ horizons of some profiles contain rock fragments of considerable size; others contain few or none. There is little or no difference in color between soil horizons over the Phosphoria Formation and corresponding soil horizons above the Park City.

Vanadium content of soil sampled ranges from 5 to $750 \mathrm{ppm}$. Inspection of table 3 demonstrates that the vanadium content of soil developed over the Park City Formation (profiles at sites 23, 24, 27) is markedly lower than that of soil developed over the phosphatic shales. The higher vanadium content of the soil over the shale units almost certainly reflects movement of vanadium from the shale into the soil. It is interesting to note that vanadium seems to be in generally lower concentrations in thick soil.

The relative distribution of chromium in soil is similar to that of vanadium. Thus the chromium content of soil over the Park City Formation $(35-350 \mathrm{ppm})$ is less than that of soil over the shales $(35-1,000 \mathrm{ppm})$. Chromium content, like vanadium content, tends to be less in thick profiles.

Zinc content of soil ranges from 125 to $1,300 \mathrm{ppm}$ over the Phosphoria and from 65 to $850 \mathrm{ppm}$ over the Park City Formation.

The barium content of soil ranges from 75 to $750 \mathrm{ppm}$ and is about the same in soil over the phosphatic shale beds as in soil over the Park City Formation. The barium in the soil, therefore, is probably derived directly from the barium in the colluvium.

Strontium content of soil samples ranges from 50 to $1,000 \mathrm{ppm}$, but samples from most profiles contain between 100 and $400 \mathrm{ppm}$. Strontium content is nearly as high in soil overlying the Park City Formation as in soil overlying the phosphatic shales. 
Phosphorus is the only element under discussion commonly considered of major importance in plant nutrition. In comparison with the underlying dragged shale layers, the soil is generally low in phosphorus content. Samples from the soil profiles overlying the shales are higher in phosphorus, however, than are normal agricultural soils, whose phosphorus content seldom exceeds 0.1 percent by weight. Samples from several soil profiles overlying the shales contain as much as 5.0 percent phosphorus (profiles 1, 9, and 14), although the average for all profiles is much lower. Phosphorus content of soil samples varies greatly but seems to be less in samples from profiles over the Park City Formation, ranging from 0.005 to 1.0 percent in profiles 23,24 , and 27 . The soil overlying the phosphatic shales has probably been enriched in phosphorus.

Copper content of the soil is low, ranging from 8 to $75 \mathrm{ppm}$; most samples contain less than $30 \mathrm{ppm}$. There seems to be no relation between the copper content of the dragged phosphate layers and the overlying soil. Soil overlying the Park City contains nearly as much copper as that overlying the Phosphoria, even though the shale units contain much more copper than does the carbonate rock that is the parent material of the soil.

Nickel in the soil is similar to copper in content and distribution. Like copper, there is no appreciable difference between the nickel content of soil overlying the Park City and that of soil overlying the Phosphoria.

Manganese content of the soil is rather high, especially in the upper soil horizons-that is, in the $A_{00}, A_{0}$, and $A$ horizons. Over both the Phosphoria and the Park City Formations, the upper soil horizons not only contain more manganese on the average than either the $\mathrm{AC}$ or the $\mathrm{C}$ soil horizons, but they are very similar in manganese content to most of the lithologic units of the phosphatic shale (pl. 1). The manganese content of the soil overlying the Park City Formation differs very little from that of most of the profiles over the phosphatic shales.

\section{VEGETATION}

Three shrub species were chosen for study: Symphoricarpos (snowberry), Ceanothus (snowbrush), and Pachistima (mountain lover). Of these three, as many species were sampled as were growing at each site where profile samples were taken. At seven sites only two of the species were present, at 15 sites only one was present. Two samples were collected from each shrub; one was of new growth and the other of older growth.

Three species of conifer-the Douglas-fir, subalpine fir, and Engelmann's spruce-were also sampled, as well as one deciduous tree-- 
the willow. Samples were collected from the north, south, east, and west sides of every tree. The new growth (branch tips) of each conifer sample was segregated from the older growth, the twigs and leaves were separated, and all sample material was air dried.

At site 21, a Douglas-fir was sampled on the north, south, east, and west, both near ground level and about 10 feet above the ground; the different types of material were separated as described in the previous paragraph. Four samples of cones were also taken, and a sample of branch wood was collected at each height on each side. Forty-four samples in all were collected from this single tree.

After the air-dried vegetation was digested by means of a perchloricnitric acid mixture, quantitative determinations for copper and zinc were made on all samples. Vanadium content of the plant samples was measured by a quantitative spectrographic method. Semiquantitative spectrographic methods were used to estimate other elements. All plant material analyzed spectrographically was ashed before analysis.

\section{MINOR ELEMENTB IN ghRUBB}

Table 4 summarizes minor-element content both of shrubs growing over the Phosphoria Formation and of shrubs growing over the Park City Formation. The data show that there are marked differences in the minor-element content of samples, not only from different plant species but also from tissues of different age from a single specimen.

\section{GNOW BERRY}

Snowberry bushes growing over the Phosphoria Formation contain more vanadium, chromium, zine, and nickel than those growing over the Park City Formation. The snowberry growing over the Park City, however, contains more barium; in the old tissue, it contains more manganese. The average values of strontium in samples of snowberry growing over the Phosphoria Formation are about the same as those in samples of this plant growing over the Park City. Copper content seems slightly higher in snowberry above the Phosphoria Formation, but the content is so low that differences may not be significant.

Young tissue of snowberry contains more nickel-but less zinc, vanadium, chromium, manganese, strontium, and barium - than older tissue contains. Phosphorus content of young tissue is higher than that of old tissue of snowberry plants growing over the Phosphoria Formation, but phosphorus content of old and young tissue is the same in plants of the same species above the Park City. Above both formations, the young tissue of snowberry contains slightly more copper than the old tissue. 
TABLE 4.-Summary of minor-element content of shrubs

[All analyses are in parts per million except phosphorus, whlch is in percent. Copper and zinc in the airdried plant material were determined quantitatively by F. B. Lotspeich, Charles Thompson, and Harry Nakagawa. Other anslyses are spectrographic determinations made on plant ash by George Boyes. Vanadium is by quantitative and all other elements are by semiquantitative spectrographic analyses]

\begin{tabular}{c|c|c|c|c|c|c|c|c|c|c|c}
\hline $\begin{array}{c}\text { Formation } \\
\text { under shrub }\end{array}$ & $\begin{array}{c}\text { Materisa } \\
\text { (tissue) }\end{array}$ & Content & $\mathrm{Cu}$ & $\mathrm{Zn}$ & $\mathrm{V}$ & $\mathrm{Cr}$ & $\mathrm{Mn}$ & $\mathrm{N1}$ & $\mathrm{Sr}$ & $\mathrm{Ba}$ & $\mathbf{P}$ \\
\hline
\end{tabular}

Symphoricarpos (snowberry)

\begin{tabular}{|c|c|c|c|c|c|c|c|c|c|c|c|}
\hline Phosphoria... & Young & $\begin{array}{l}\text { Max } \\
\text { Min }\end{array}$ & $\begin{array}{r}18 \\
2 \\
6\end{array}$ & $\begin{array}{l}55 \\
20 \\
34\end{array}$ & $\begin{array}{l}80 \\
11 \\
26\end{array}$ & $\begin{array}{r}100 \\
\text { Trace }\end{array}$ & $\begin{array}{r}1,000 \\
100\end{array}$ & $\begin{array}{r}100 \\
10\end{array}$ & $\begin{array}{r}1,500 \\
750\end{array}$ & $\begin{array}{r}350 \\
75 \\
270\end{array}$ & $\begin{array}{l}4.0 \\
1.0\end{array}$ \\
\hline & Old........... & $\begin{array}{l}\text { Max } \\
\text { Min } \\
\text { Avg }\end{array}$ & $\begin{array}{l}6 \\
2 \\
4\end{array}$ & $\begin{array}{l}80 \\
36 \\
58\end{array}$ & $\begin{array}{r}110 \\
30 \\
90\end{array}$ & $\begin{array}{r}200 \\
50\end{array}$ & $\begin{array}{r}5,000 \\
500\end{array}$ & $\begin{array}{l}50 \\
10\end{array}$ & $\begin{array}{r}1,1000 \\
750 \\
1,250\end{array}$ & $\begin{array}{l}2,000 \\
1,000 \\
1,280\end{array}$ & $\begin{array}{l}2.0 \\
0.5\end{array}$ \\
\hline Park City.... & & Max. & $\begin{array}{l}4 \\
6 \\
1 \\
4\end{array}$ & $\begin{array}{l}24 \\
20 \\
23\end{array}$ & $\begin{array}{l}<10 \\
<10\end{array}$ & $\begin{array}{r}50 \\
0\end{array}$ & $\begin{array}{l}500 \\
200\end{array}$ & $\begin{array}{r}20 \\
5\end{array}$ & $\begin{array}{r}1,200 \\
750 \\
750 \\
750\end{array}$ & $\begin{array}{r}1,200 \\
350 \\
200 \\
300\end{array}$ & $\begin{array}{l}2.0 \\
1.0\end{array}$ \\
\hline & old. & $\begin{array}{l}\text { Max. } \\
\text { Min } \\
\text { A vg }\end{array}$ & $\begin{array}{l}3 \\
4 \\
2 \\
3\end{array}$ & $\begin{array}{l}48 \\
24 \\
38\end{array}$ & $\begin{array}{r}59 \\
29 \\
42\end{array}$ & $\begin{array}{l}50 \\
20\end{array}$ & $\begin{array}{r}10,000 \\
2,000\end{array}$ & 20 & $\begin{array}{r}1,500 \\
750 \\
1,250\end{array}$ & $\begin{array}{l}2,000 \\
1,500 \\
1,670\end{array}$ & $\begin{array}{l}2.0 \\
1.0\end{array}$ \\
\hline
\end{tabular}

Ceanothus (snowbrash)

\begin{tabular}{|c|c|c|c|c|c|c|c|c|c|c|c|}
\hline Park City_. & $\begin{array}{l}\text { Young } . . . \\
\text { Old....... }\end{array}$ & $\begin{array}{l}\text { Max } \\
\text { Min } \\
\text { Avg } \\
\text { Max } \\
\text { Min } \\
\text { Avg }\end{array}$ & $\begin{array}{r}3 \\
1 \\
2 \\
3 \\
1 \\
1 \\
1.3 \\
2\end{array}$ & $\begin{array}{r}36 \\
22 \\
29 \\
20 \\
8 \\
14 \\
4\end{array}$ & $\begin{array}{l}60 \\
21 \\
45 \\
46 \\
22 \\
37 \\
23\end{array}$ & $\begin{array}{r}100 \\
20\end{array}$ & $\begin{array}{r}1,000 \\
200 \\
600 \\
200 \\
350\end{array}$ & $\begin{array}{r}100 \\
10\end{array}$ & $\begin{array}{r}1,500 \\
750 \\
1,000 \\
3,500 \\
350 \\
2,300 \\
1,500\end{array}$ & $\begin{array}{l}150 \\
100 \\
140 \\
500 \\
200 \\
350 \\
500\end{array}$ & $\begin{array}{l}2.0 \\
1.0 \\
2.0 \\
0.5\end{array}$ \\
\hline
\end{tabular}

Pachistima (mountain lover)

\begin{tabular}{|c|c|c|c|c|c|c|c|c|c|c|c|}
\hline Phosphoria & $\begin{array}{l}\text { Young-...- } \\
\text { Old........ }\end{array}$ & $\begin{array}{l}\text { Max. } \\
\text { Min. } \\
\text { Avg } \\
\text { Max. } \\
\text { Min } \\
\text { Avg }\end{array}$ & $\begin{array}{r}5 \\
<1 \\
3 \\
5 \\
2 \\
3 \\
6\end{array}$ & $\begin{array}{l}50 \\
30 \\
38 \\
90 \\
50 \\
60 \\
40\end{array}$ & $\begin{array}{l}70 \\
18 \\
41 \\
81 \\
42 \\
64 \\
32\end{array}$ & \begin{tabular}{r}
100 \\
10 \\
\hdashline 100 \\
20 \\
35
\end{tabular} & $\begin{array}{r}1,000 \\
100 \\
1,000 \\
100 \\
750\end{array}$ & $\begin{array}{r}100 \\
10 \\
10 \\
10\end{array}$ & $\begin{array}{r}1,500 \\
750 \\
1,270 \\
3,500 \\
1,500 \\
1,930 \\
1,500\end{array}$ & $\begin{array}{r}350 \\
75 \\
240 \\
750 \\
200 \\
520 \\
750\end{array}$ & $\begin{array}{r}5.0 \\
1.0 \\
2.0 \\
0.5\end{array}$ \\
\hline
\end{tabular}

SNOWBRUGF

Snowbrush shrubs growing over the Phosphoria Formation contain more zinc, vanadium, chromium, nickel, and phosphorus than those growing over the Park City; barium is higher in these plants above the Park City. There is no significant difference in content of either manganese or copper between snowbrush growing over the Phosphoria and snowbrush over the Park City.

Differences between metal content of young tissue and of old tissue of snowbrush are not as marked as those of snowberry. Only small differences in vanadium, chromium, manganese, nickel, and phosphorus content exist between young and old tissue. In young tissue of snowbrush, however, the zinc content is definitely higher and the strontium content lower than that in old tissue. There seems to be no significant variation in copper content.

\section{MOUNTAIN LOVER}

Young tissue of the shrub mountain lover contains more manganese, nickel, and phosphorus than old tissue. Old tissue, however, contains 
more zinc, vanadium, chromium, strontium, and barium. Young and old tissue contain about the same amount of copper.

Old tissue from mountain lover growing over the Phosphoria Formation contains more vanadium, chromium, zinc, nickel, and phosphorus but less manganese and barium than that from mountain lover growing over the Park City Formation. In samples of mountain lover, copper concentrations are too low to permit definite conclusions. There seems to be no consistent pattern of distribution of strontium.

\section{MINOR ELEMENTS IN TREES}

Table 5 presents data showing the minor-element content of leaves (or needles) and twigs taken from four species of trees, some of which were sampled over the Phosphoria Formation and some over the Park City Formation. For this table, analytical results on young and old tissue of leaves or twigs have been averaged for each species for purposes of comparison of concentrations in these tissues over the two formations.

To learn whether significant differences in metal content exist between the same plant tissue of different ages and in different places on a single tree, 44 samples from a Douglas-fir at site 21 (fig. 4) were collected and analyzed. The results (table 6 ) show that some of these differences are considerable.

DOUGLAG-FIR

Both needles and twigs of Douglas-fir growing over the phosphatic shales contain considerably more strontium and slightly more vanadium than needles and twigs of Douglas-fir growing over the Park City Formation. Zinc, barium, and manganese are higher in both needles and twigs of the Douglas-fir growing over the Park City Formation. Chromium, phosphorus, copper, and nickel content of both needles and twigs are nearly the same in samples from trees over both formations. The data in table 5 show that in Douglas-fir trees vanadium and barium tend to be more highly concentrated in twigs and that manganese is more highly concentrated in needles.

The data in table 6 show that among samples from the same Douglasfir tree, not only does the content of a given element differ appreciably in needles and twigs, but the content similarly differs between old needles and young needles.

Vanadium concentration, for example, is greatest in cones and lowest in branch wood 10 feet above the ground. The second highest vanadium content is in young needles near the ground. Old twigs, however, contain more vanadium than either old needles or young twigs. 
TABLE 5.-Comparison of minor-element composition of leaves (or needles) and twigs from four species of trees growing over the Phosphoria Formation and Park City Formation

[All analyses are in parts per million except phosphorus, which is in percent. Copper and zinc in the air-dried plant material were determined quantitatively by F. B. Lotspelch. Charles Thompson, and Harry Nakagawa. Other analyses are spectrographic determinations made on plant ash by George Boyes. Vanadium is by quantitative and all other elements are by semlquentitative spectrographic analyses]

\begin{tabular}{|c|c|c|c|c|c|c|c|c|c|c|c|c|c|c|}
\hline \multirow{3}{*}{ Element } & \multicolumn{4}{|c|}{ Douglas-fir } & \multicolumn{4}{|c|}{ Subalpine fir } & \multicolumn{4}{|c|}{ Engelmann's spruce } & \multicolumn{2}{|c|}{ Willow } \\
\hline & \multicolumn{2}{|c|}{ Phosphoria } & \multicolumn{2}{|c|}{ Park City } & \multicolumn{2}{|c|}{ Phosphoria } & \multicolumn{2}{|c|}{ Park Ctty } & \multicolumn{2}{|c|}{ Phosphoria } & \multicolumn{2}{|c|}{ Park City } & \multirow{2}{*}{$\begin{array}{l}\text { Phos- } \\
\text { phoria }\end{array}$} & \multirow{2}{*}{$\begin{array}{l}\text { Park } \\
\text { City }\end{array}$} \\
\hline & Leaves & Twigs & Lasves & Twigs & Leaves & Twigs & Lesves & Twigs & Leaves & Twigs & Lesves & Twigs & & \\
\hline 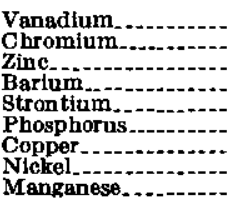 & $\mid \begin{array}{r}31 \\
20-50 \\
36 \\
1,380 \\
6,250 \\
.2-.6 \\
2 \\
10-20 \\
1,000-2,000\end{array}$ & $\begin{array}{r}20-50 \\
37 \\
1,620 \\
6,500 \\
6-1.0 \\
4 \\
10-20 \\
500-1,000\end{array}$ & $\left|\begin{array}{r}14 \\
10-20 \\
53 \\
1,880 \\
4,250 \\
.2-.5 \\
3 \\
5-10 \\
2,000-5,000\end{array}\right|$ & \begin{tabular}{|r}
$20-50$ \\
41 \\
2,120 \\
3,500 \\
$.5-1.0$ \\
4 \\
$10-20$ \\
$1,000-2,000$
\end{tabular} & $\begin{array}{r}22 \\
20-50 \\
68 \\
3,880 \\
1,500 \\
.6-1.0 \\
2 \\
5-10 \\
1,000-2,000\end{array}$ & $\mid \begin{array}{r}48 \\
50-100 \\
51 \\
6,200 \\
1,250 \\
1.0-2.0 \\
10-20 \\
1,000-2,000\end{array}$ & $\mid \begin{array}{r}12 \\
\mathrm{Tr} \\
55 \\
3,380 \\
1,310 \\
.2-.5 \\
4 \\
2-5 \\
2,000-5,000\end{array}$ & \begin{tabular}{|r|}
29 \\
$10-20$ \\
26 \\
3,000 \\
810 \\
$1.0-2.0$ \\
5 \\
$5-10$ \\
$1,000-2,000$
\end{tabular} & $\begin{array}{r}33 \\
10-20 \\
108 \\
3.000 \\
1,880 \\
1.0-2.0 \\
2 \\
5-10 \\
2,000-5,000\end{array}$ & $\mid \begin{array}{r}116 \\
100-200 \\
76 \\
6,200 \\
3,100 \\
1.0-2.0 \\
4 \\
20-50 \\
2,000-5,000\end{array}$ & $\mid \begin{array}{r}13 \\
10-20 \\
44 \\
2,220 \\
1,620 \\
.2-.5 \\
1 \\
2-5 \\
2,000-5,000\end{array}$ & $\mid \begin{array}{r}52 \\
20-50 \\
62 \\
3,500 \\
1,500 \\
.2-.5 \\
4 \\
5-10 \\
1,000-2,000\end{array}$ & $\left|\begin{array}{r}16 \\
10-20 \\
145 \\
5.50 \\
1,600 \\
.5-1.0 \\
3 \\
10-20 \\
200-500\end{array}\right|$ & $\begin{array}{r}40 \\
T r . \\
81 \\
420 \\
1,060 \\
.2-5 \\
4 \\
2-5 \\
200-500\end{array}$ \\
\hline
\end{tabular}


TABLE 6.-Minor-element composition of Douglas-fir tree at site 21

[All elements expressed in parts per million except phosphorus, which is in percent. Copper and zinc were determined quantitatively in the air-dried plant materlal by F. B. Lotspeich, Oharles Thompson, and. Harry Nakagawa. Other analyses are spectrographic determinations made on plant ash by George Boyes. Vanadium is by quantitstive and all other elements are by semiquantitative spectrographic anglyses]

\begin{tabular}{|c|c|c|c|c|c|c|c|c|c|c|c|}
\hline \multirow{3}{*}{ Element } & \multicolumn{4}{|c|}{ Near ground } & \multicolumn{4}{|c|}{10 feet above ground } & \multicolumn{3}{|c|}{ Branch wood } \\
\hline & \multicolumn{2}{|c|}{ Young } & \multicolumn{2}{|c|}{ old } & \multicolumn{2}{|c|}{ Young } & \multicolumn{2}{|c|}{ old } & \multirow{2}{*}{$\begin{array}{l}\text { Near } \\
\text { ground }\end{array}$} & \multirow{2}{*}{$\begin{array}{l}10 \text { feet } \\
\text { above } \\
\text { ground }\end{array}$} & \multirow{2}{*}{ Cones } \\
\hline & Leaves & Twigs & Lesves & Twigs & Lebves & Twigs & Leaves & Twigs & & & \\
\hline 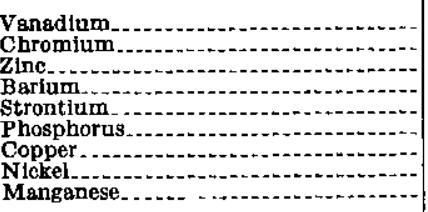 & $\begin{array}{r}71 \\
50-100 \\
32 \\
1,300 \\
3,500 \\
2-4 \\
4 \\
20-50 \\
500-1,000\end{array}$ & $\begin{array}{r}39 \\
50-100 \\
56 \\
1,440 \\
3,500 \\
2-4 \\
13 \\
20-50 \\
200-500\end{array}$ & $\begin{array}{r}37 \\
20-50 \\
33 \\
1,120 \\
3,870 \\
1-2 \\
5 \\
5-10 \\
1,000-2,000\end{array}$ & $\begin{array}{r}51 \\
20-50 \\
62 \\
1,500 \\
4,250 \\
1-2 \\
6 \\
20-50 \\
500-1,000\end{array}$ & $\begin{array}{r}45 \\
20-50 \\
30 \\
1,000 \\
2,380 \\
1-2 \\
4 \\
20-50 \\
1,000-2,000\end{array}$ & $\begin{array}{r}42 \\
20-50 \\
44 \\
750 \\
2,120 \\
1-2 \\
7 \\
20-50 \\
500-1,000\end{array}$ & $\begin{array}{r}34 \\
20-50 \\
24 \\
1,060 \\
3,100 \\
1-2 \\
2 \\
5-10 \\
1,000-2,000\end{array}$ & $\begin{array}{r}43 \\
20-50 \\
48 \\
1,310 \\
3,500 \\
1-2 \\
4 \\
20-50 \\
500-1,000\end{array}$ & $\begin{array}{r}20 \\
20-50 \\
22 \\
1,320 \\
3,880 \\
2-4 \\
4 \\
5-10 \\
200-500\end{array}$ & $\begin{array}{r}14 \\
10-20 \\
12 \\
1,620 \\
3,500 \\
0.5-1 \\
2 \\
5-10 \\
200-500\end{array}$ & $\begin{array}{r}112 \\
50-100 \\
8 \\
500 \\
750 \\
2-4 \\
3 \\
20-50 \\
200-500\end{array}$ \\
\hline
\end{tabular}


Chromium is rather evenly distributed. The old leaves and twigs, the young leaves and twigs 10 feet above the ground, and the branches near the ground have about the same content; young leaves and twigs near the ground have a slightly higher chromium content, as do cones; branch wood 10 feet above the ground is slightly lower in chromium.

The zinc content of twigs is higher than that of leaves, and old twigs contain more zinc than young twigs. Samples at the 10 -foot height contain less zinc than those at ground level. Both branch wood and cones are lower in zinc than either leaves or twigs. Distribution of copper is about the same as that of zinc.

Barium content is higher in twigs than it is in leaves, except for the young twigs sampled 10 feet above the ground. The highest barium content, however, is in branch wood at a height of 10 feet.

Old tissue contains more strontium than young tissue, and strontium content of all.samples tends to be higher at ground level than at 10 feet above ground. Branch wood has about the same strontium content as twigs and leaves; cones contain the least amount of strontium.

Phosphorus content is higher in new tissue than in old tissue in samples from ground level, but in samples of new and old tissue from 10 feet above ground there is no difference in phosphorus content. Branch wood from ground level contains more phosphorus than a similar sample from 10 feet above ground. Cones contain as much phosphorus as young leaves and twigs.

Nickel content of young leaves is the same as that of young twigs; in older tissue, twigs contain more nickel than leaves, and cones contain as much nickel as twigs. The nickel content of branch wood is low.

Regardless of age of tissue or position of tissue on the tree, leaves contain about twice as much manganese as twigs. Branch wood and cones have about the same manganese content, nearly one-half the content of twigs.

\section{SUBALPINE FIR}

Analyses of vanadium, chromium, zinc, barium, strontium, and nickel are definitely lower in samples from subalpine fir trees growing over the Park City Formation than in samples from trees of the same kind growing over the Phosphoria, whereas copper content tends to be slightly higher in trees over the Park City. Phosphorus content of needles is about the same, whether the sample came from a tree over the Phosphoria or over the Park City, and phosphorus content of twigs is also the same in samples from trees over both formations. Manganese content of needles is higher in samples from trees over the Park City, but manganese content of twigs from trees over the Park City is the same as that of twigs from trees over the Phosphoria. In 
twigs, vanadium, chromium, and phosphorus concentrations are higher than in needles; zinc, barium, and strontium concentrations, however, are higher in needles than in twigs.

\section{ENGELMANN'G GPRUCE}

Samples from a spruce tree growing over the Phosphoria Formation contain more vanadium, zinc, barium, strontium, phosphorus, and nickel than samples from the same species of trees growing over the Park City Formation. Twigs contain more vanadium, chromium, barium, and nickel than needles. Results for the other elements show no significant variations.

\section{WILLOW}

In samples from a willow tree growing over the Phosphoria Formation, chromium, zinc, barium, strontium, phosphorus, and nickel contents were higher than in samples from a willow tree growing over the Park City Formation. Vanadium content, however, is higher in samples from the tree growing over the Park City. In copper content the difference between the trees is negligible. Samples from the willow growing over the Phosphoria Formation have the highest zinc content of all the vegetation samples analyzed for this study.

\section{DISCUSSION AND SUMMARY OF DATA ON MINOR ELEMENTS}

In considering the data amassed in this investigation, certain plantsubstrate relations (Goldschmidt, 1954) should be kept in mind. Roots of plants extract from the substrate the elements that are then translocated to stems, leaves, flowers, and fruits; after these plant parts die, fall to the ground, and are decomposed, the elements enter and enrich the soil.

The soil at every profile-sampling site over the Phosphoria Formation, except site 22 , is underlain by one or more colluvially dragged layers of phosphatic shale, and many of the plants sampled were rooted in these metal-rich dragged layers. Where the soil is less than 24 inches thick, the roots of the snowberry and mountain lover shrubs penetrate the dragged shale. Snowbrush, however, has a root system that in some places penetrates bedrock at depths of 8 to 10 feet. The roots of the trees also may extend considerable distances both vertically and laterally.

\section{BARIUM}

In the unweathered phosphatic shale beds of the Meade Peak Member of the Phosphoria Formation, barium probably has a random distribution in relation to phosphorus content, although plate 1 shows a possible rough inverse correlation of barium with both phosphorus 
and strontium. The highest barium contents are in layers having considerable muddy or silty constituents. Plate 1 shows a slight general increase of barium with increase of weathering in most of the rock units studied; the greatest increase is in the mudstone units, especially the marker bed of calcareous mudstone near the middle of the section. Barium content is lower in the colluvially dragged layers, however, than in bedrock.

Table 3 shows that the barium content of the weathered carbonate rock of the Park City Formation is much lower than that of the phosphatic shales of the Phosphoria Formation. Nevertheless, the barium content of the soil is about the same over the two formations. Inasmuch as the barium content of the soil is higher in the upper horizons than in the lower and the barium content of shrubs and soil seems not to be influenced by barium content of either underlying dragged shale layers or bedrock, it seems probable that the plants are obtaining barium from the colluvium and are concentrating it in the upper horizons of the soil.

\section{CHROMIUM}

The distribution of chromium in unweathered shale units is similar to that of nickel and zinc and to a certain extent to that of barium. The chromium content of the unweathered shale is greatest in argillaceous rocks having a phosphorus content of 2.5 to 6 percent. Plate 1 shows that most rock units, especially mudstone, have undergone chromium enrichment with weathering. The greatest increase in chromium content has taken place in a unit of argillaceous phosphate rock in the interval 116 to 121 feet from the chert; a notable, but exceptional, decrease with weathering has occurred in the highly calcareous mudstone marker bed near the middle of the section.

The maximum chromium content of the phosphatic shale beds is $2,000 \mathrm{ppm}$ for bedrock and $3,500 \mathrm{ppm}$ for dragged layers; the chromium content of dragged layers generally is slightly higher than that of bedrock (table 3 ). The chromium content of the carbonate rock in the Park City Formation is $70 \mathrm{ppm}$.

Chromium content of all soil horizons is noticeably higher for soils over the Phosphoria Formation than those over the Park City. The same is true of chromium content of plants.

\section{COPPER}

Distribution of copper in the unweathered shale is somewhat similar to that of chromium (except that the amounts are less) and very similar to that of nickel, except, in the thin marker bed of calcareous mudstone mentioned previously. Most of the minimum copper values are for rocks having the lowest content of phosphorus, and most of 
the maximum values are for argillaceous rocks of high organic content but only moderately high phosphorus content-2.5 to 7.5 percent.

In most rock units the copper content of weathered rock equals or exceeds that of unweathered rock (pl. 1). In two units of phosphate rock, weathered rock contains less than unweathered rock, but the differences-25 and $50 \mathrm{ppm}-$ seem negligible. Two weathered units of argillaceous phosphate rock show copper enrichment of 250 and $150 \mathrm{ppm}$ respectively.

The copper content of weathered rock from the Park City Formation was measured as less than $10 \mathrm{ppm}$. The range of copper values in the weathered shales in place is 7 to $500 \mathrm{ppm}$ as shown in table 2; table 3 shows only 15 to $150 \mathrm{ppm}$. The range of copper content in the dragged shales is 20 to $250 \mathrm{ppm}$; the maximum copper content is in a layer at site 19 that could be traced to where it is a bed in place 30 to 40 feet away.

The copper content of soil over the Phosphoria is low but is slightly more than that of soil over the Park City-a range of 8 to $75 \mathrm{ppm}$ as compared to a range of 8 to $19 \mathrm{ppm}$. The range of copper content of shrubs over the Phosphoria is less than 1 to $18 \mathrm{ppm}$; that of shrubs over the Park City is 2 to 6 ppm.

\section{MANGANESE}

The range of manganese content for fresh bedrock of the Phosphoria Formation examined in this study is 10 to $500 \mathrm{ppm}$. In the distribution of elements in the unweathered Meade Peak Member, there is a rough inverse correlation of manganese with phosphorus; the four minimum manganese values were for rocks having a phosphorus content of 7.5 percent or more, and the five maximum manganese values were for rocks having a phosphorus content of 2 percent or less.

In the weathered shale units, the range of manganese content is from less than 10 to as much as $3,500 \mathrm{ppm}$; minimum and maximum manganese values seem to be randomly distributed in relation to phosphorus. In most of the lithologic units studied, differences in manganese content are negligible between unweathered and weathered phosphatic shales. In the six units shown on plate 1 in which the manganese content is greater in the fresh rocks, $140 \mathrm{ppm}$ is the maximum difference between unweathered and weathered material; in four of the six units in which manganese concentration is higher in the weathered rocks, the difference is less than $75 \mathrm{ppm}$. In only one rock unit is the contrast striking; the thin marker bed of highly calcareous mudstone previously mentioned contains only $50 \mathrm{ppm}$ manganese where unweathered, but $1,500 \mathrm{ppm}$ manganese where weathered. 
The manganese content of the bedrock sample from the Park City Formation is $50 \mathrm{ppm}$.

Table 3 shows the samples of dragged shale to be generally lower in manganese content ( 10 to $750 \mathrm{ppm})$ than the shale in place (10 to $3,500 \mathrm{ppm})$. Manganese content of soil is rather high, and is about the same over both formations except in the organic horizons $\mathbf{A}_{00}$ and $\mathbf{A}_{0}$, which have manganese contents that are definitely greater over the Phosphoria Formation that over the Park City. Apparently plants concentrate the manganese and enrich these horizons, and possibly the A horizon as well.

\section{NICKEL}

In distribution, amount, and general relations with other elements and with all the lithologic units except one, nickel content is similar to copper content of the phosphatic shale. In unweathered rocks having a phosphorus content of 1 percent or less, all but one of the samples having minimum nickel contents are from the same layers that have minimum copper contents. The maximal values of nickel like those of copper are for rocks having muddy constituents and intermediate phosphorus content. In weathered rocks, nickel, like copper, shows random distribution in relation to phosphorus content. The range of nickel content in the shale is from less than 3 to as much as $550 \mathrm{ppm}$ in unweathered rock and from less than 5 to as much as $750 \mathrm{ppm}$ in weathered rock. The nickel content of the sample from the Park City Formation was $20 \mathrm{ppm}$.

Plate 1 shows little difference in nickel content between fresh and weathered rock units. In high grade phosphate rock and in the marker unit of calcareous mudstone, nickel content is greater in unweathered rock; the nickel content of most mudstones and other argillaceous rocks is a little higher in unweathered rock. Table 3 shows that the nickel content of shales in place is slightly more (20 to 750 $\mathrm{ppm}$ ) than of dragged layers (20 to $150 \mathrm{ppm}$ ).

The $\mathrm{C}$ and the $\mathrm{AC}$ horizons of soil have about the same nickel content over the Phosphoria Formation as over the Park City. In the upper horizons -the $\mathbf{A}_{00}, \mathbf{A}_{0}$, and $\mathbf{A}$-as well as in the shrubs, nickel content is greater over the Phosphoria. It seems that plant uptake of nickel must be responsible for the concentration of nickel at the upper levels of the soil.

\section{STRONTIUM}

The range of strontium values is the same in both fresh and weathered phosphatic shales: 100 to $3,500 \mathrm{ppm}$. In the unweathered rocks there is a definite positive correlation between strontium and phosphorus regardless of lithology; the maximum values of both ele- 
ments occur in the same layers and the minimum values coincide as well. There is a rough positive correlation between strontium and phosphorus content in weathered rocks also.

Weathering has not caused any obvious consistent changes in strontium content of the several rock units. In 5 of the 12 lithologic units of shale, however, weathering has resulted in a change of strontium content of $500 \mathrm{ppm}$ or more. Three of these units contain substantially more strontium where they are unweathered than where weathered, but in the other 2 units of the 5, strontium content is higher in the weathered rock. The most notable change has occurred in the thin marker bed of calcareous mudstone, in which weathering seems to have decreased the strontium content from 3,500 to $200 \mathrm{ppm}$ and the phosphorus content from 10 percent to 0.25 percent. Weathering apparently has increased strontium content from 600 to $1,800 \mathrm{ppm}$ in a unit of argillaceous phosphate rock in the interval 116 to 121 feet from the chert. In the other 7 units of the 12 studied, differences are negligible. The sample of bedrock from the Park City Formation contained $100 \mathrm{ppm}$ strontium.

Strontium content of dragged layers of shale is not as high as that of equivalent bedrock layers. In the soil over both formations, strontium content increases progressively upward from the deepest horizon, C, through the A horizon. Both soil and shrub samples collected over the Phosphoria Formation contain more strontium than those collected over the Park City. Again, increases in the metal content in the upper soil horizons may be the result of concentration by plants.

\section{VANADIUM}

Vanadium content of the shales ranges from 35 to $5,000 \mathrm{ppm}$ in the unweathered shale and 20 to $5,000 \mathrm{ppm}$ in the weathered shale. There seems to be a rough positive correlation of vanadium with phosphorus and strontium. In 10 of the 12 lithologic units studied, the vanadium content is higher in weathered rock than in unweathered rock. In most of the weathered units the increase in vanadium is between 100 and $300 \mathrm{ppm}$; in two units of argillaceous phosphate rock, however, the difference is greater -600 and $1,600 \mathrm{ppm}$. The vanadium content of the bedrock sample from the Park City Formation was $100 \mathrm{ppm}$.

In general, vanadium content of the dragged shale is about the same as in the bedrock. The mineral horizons of the soil over the Phosphoria Formation contain substantially more vanadium (50 to $750 \mathrm{ppm}$ ) than do the analogous horizons over the Park City (35 to $100 \mathrm{ppm})$. The vanadium content of organic horizons of the soil over the Phosphoria Formation range from 28 to $147 \mathrm{ppm}$, as compared with a range from 5 to $35 \mathrm{ppm}$ over the Park City Formation. Vana- 
dium content of shrubs ranges from 10 to $110 \mathrm{ppm}$ over the Phosphoria and from 10 to $39 \mathrm{ppm}$ over the Park City.

In 15 of the 22 profiles studied, vanadium content of the lower soil horizons (C and $\mathrm{AC}$ ) is greater than that of the upper horizons $\left(\mathbf{A}, \mathbf{A}_{0}\right.$, and $\left.\mathbf{A}_{00}\right)$. In four profiles $(2,13,16,19)$ maximum values of vanadium in lower and upper horizons are equal, and in three profiles $(14,17,21)$ the vanadium content of the upper horizons exceeds that of the lower. In soils whose total thickness is 40 inches or more, maximum vanadium content is $100 \mathrm{ppm}$; for those profiles wherein the underlying shales have a high vanadium content, one might expect a correlation between soil thickness and vanadium content of soil. Some profiles seem to support this premise, but data for an equal number of profiles seem to disprove it. Illustrative examples follow.

In profile 1, in which vanadium content of soil is greatest, $750 \mathrm{ppm}$, the thickness of the soil is 24 inches and the highest vanadium content of the shale is only $200 \mathrm{ppm}$. In profile 4 , in which the thickness of soil is the same as that of profile 1 , vanadium content of the shale ranges from 350 to $3,500 \mathrm{ppm}$, but the range of vanadium in the soil is only 30 to $150 \mathrm{ppm}$. In profile 2 , in which soil thickness is 14 inches, there is a maximum vanadium content of $1,500 \mathrm{ppm}$ in the shales but a maximum of only $200 \mathrm{ppm}$ in the overlying soil. In the 18-inch soil of profile 3 , the highest vanadium value is only $75 \mathrm{ppm}$, although vanadium content of underlying shale has a maximum of $1,500 \mathrm{ppm}$. In profiles 14 and 15, however, having soil thickness of 24 and 29 inches, respectively, the maximum vanadium content of shale at both sites is $500 \mathrm{ppm}$, but vanadium content of the one overlying soil is $500 \mathrm{ppm}$ and of the other is $350 \mathrm{ppm}$.

\section{ZINC}

In unweathered shale in place, the range in zinc content is 20 to $7,000 \mathrm{ppm}$. The maximum value is for a sample from a bed of argillaceous phosphate rock having a phosphorus content of 7.5 percent; all the high zine values $(3,000$ to $7,000 \mathrm{ppm})$ are for muddy or silty rocks having phosphorus contents ranging from 3.75 to 7.5 percent. Rocks of the minimum phosphorus contents have minimum zinc contents. Evidently there is a direct correlation between zinc and phosphorus in shales of high silty content; in the weathered shale, however, this relation is not apparent.

In general, the effect of weathering seems to equalize zinc distribution; the range of zinc content is much less in weathered shale than in unweathered shale.

For 9 of the 12 lithologic units shown on plate 1, average zinc content is higher in the unweathered rock than in the weathered; for one 
unit, average zinc content is the same in both; in the remaining two units, zinc content of the weathered rock is the higher. The range of zinc content of weathered shale is 200 to $2,500 \mathrm{ppm}$; in the dragged layers the range is 300 to $2,000 \mathrm{ppm}$. The zinc content of the sample from the Park City is $350 \mathrm{ppm}$.

All soil horizons above the Phosphoria have higher zinc contents respectively than comparable horizons above the Park City. The zinc content of the shrubs over the Phosphoria is higher also than that over the Park City.

\section{CONCLUSIONS}

Both metal-poor colluvium and the soil developed on it can be enriched by metallic elements from the substrata, if the metal content of the underlying beds is sufficient and in an available form. It is believed that the metabolic processes of vegetation growing in the soil constitute an important if not a necessary factor of the mechanism through which the enricliment is accomplished. The metal content of either plants or soil, therefore, may be evidence of a metal-rich substratum if proper sampling has been done. To obtain a comprehensive picture by plant sampling, material for analysis must be collected not only from different species, but also from tissues of different type and age. Comparisons of metal content, however, should be made only between analytical results on plant samples of the same species and age and on analogous tissue.

Before soil samples are collected, consideration must be given to the stage of development of the soil to be sampled. In the area studied, although little difference was noted in the metal content of adjacent horizons of the poorly developed soils, it is a well-substantiated fact that a noticeable difference exists in the metal content of adjacent horizons of soils in which soil development is advanced. It follows that in pedogeochemical investigations of regions with mature soils, the investigator must take the samples to be compared from the same soil horizons, if comparisons of their metal content are to be valid.

Where a surface slopes, even very gently, an investigator seeking the source of a metal anomaly should remember three facts documented by this study: (1) that colluvium may move, without much internal mixing, for great distances downhill; (2) that upended metalrich layers of rock can be dragged by moving colluvium for tens or even hundreds of feet downslope as identifiable units with little mixing and almost no significant change in characteristics except thinning; and (3) that anomalous concentrations of metal in the colluvium, in the soil developed on it, or in plants growing on the soil may have been derived from such displaced metal-rich layers rather than from the bedrock directly beneath the colluvial mantle. 


\section{SELECTED REFERENCES}

Almond, Hy, 1955, Rapid field and laboratory method for the determination of copper in soil and rocks: U.S. Geol. Survey Bull. 1036-A, 8 p.

Canney, F. C., Myers, A. T., and Ward, F. N., 1957, A truck-mounted spectrographic laboratory for use in geochemical exploration: Econ. Geology, v. 52, no. 3, p. 289-306.

Connor, Jane, Shimp, N. F., and Tedrow, J. C. F., 1957, A spectrographic study of the distribution of trace elements in some podzolic soils: Soil Sci., v. 83, p. 65-73.

Daridson, D. F., Smart, R. A. Peirce, H. W., and Weiser, J. D., 1953, Stratigraphic sections of the Phosphoria Formation in Idaho, 1949, pt. 2 : U.S. Geol. Survey Circ. $305,28 \mathrm{p}$.

Goldschmidt, V. M., 1954, Geochemistry: Oxford, Clarendon Press, 730 p.

Hawkes, H. E., 1950, Geochemical prospecting for ores, in Trask, P.D., Applied Sedimentation: New York, John Wiley \& Sons, p. 537-555.

Holmes, R. S., 1945, Determination of total copper, zinc, cobalt, and lead in soils and soil solutions: Soil Sci., v. 59, p. 77-84.

Kilmer, O. J., and Alexander, L. T., 1949, Methods of making mechanical analyses of soils : Soil Sci., v. 68, p. 15-24.

Mansfleld, G. R., 1927, Geography, geology, and mineral resources of part of southeastern Idaho: U.S. Geol. Survey Prof. Paper 152, $453 \mathrm{p}$.

McKelvey, V. E., 1949, Geological studies of the western phosphate field: Am. Inst. Mining Metall. Engineers Trans., v. 184, p. 270-279.

McKelvey, V. E., Davidson, D. F., O'Malley, F. W., and Smith, L. E., 1953, Stratigraphic sections of the Phosphoria Formation in Idabo, 1947-1948, pt. 1 : U.S. Geol. Survey Circ. 208, 49 p.

McKelvey, V. E., and others, 1959, The Phosphoria, Park City, and Shedhorn Formations in the western phosphate field: U.S. Geol. Survey Prof. Paper 313-A, p. 1-47.

McKelvey, V. E., Swanson, R. W., and Sheldon, R. P., 1953, The Permian phosphorite deposits of western United States: Internat. Geol. Cong., 19th, Algiers 1952, Comptes rendus, sec. 11, p. 45-64.

O'Malley, F. W., Davidson, D. F., Hoppin, R. A., and Sheldon, R. P., 1953, Stratigraphic sections of the Phosphoria Formation in Idaho, 1947-48, pt. 3 : U.S. Geol. Survey Circ. 262, 43 p.

Sheldon, R. P., Warner, M. A., Thompson, M. E., and Peirce, H. W., 1953, Stratigraphic sections of the Phosphoria Formation in Idaho, 1949, pt. 1: U.S. Geol. Survey Circ. 304, 30 p.

Smart, R. A., Waring, R. G., Cheney, T. M., and Sheldon, R. P., 1954, Stratigraphic sections of the Phosphoria Formation in Idaho, 1950-51: U.S. Geol. Survey Circ. 327, 22 p.

Snell, Foster Dee, and Snell, Cornelia T., 1949, Colorimetric methods of analysis, v. 2: D. Van Nostrand Co., Inc., 1950 p.

Swanson, R. W., Carswell, L. D., Sheldon, R. P., and Cheney, T. M., 1956, Stratigraphic sections of the Phosphoria Formation, 1953: U.S. Geol. Survey Circ. 375,30 p.

U.S. Soil Survey Staff, 1951, Soil Survey Manual: U.S. Dept. Agriculture Bandb. $18,503 \mathrm{p}$.

Warren, B. V., Delavault, R. E., and Irish, R. I., 1952, Biogeochemical investigations in the Pacific northwest: Geol. Soc. America Bull., v. 63, p. 435-484. 



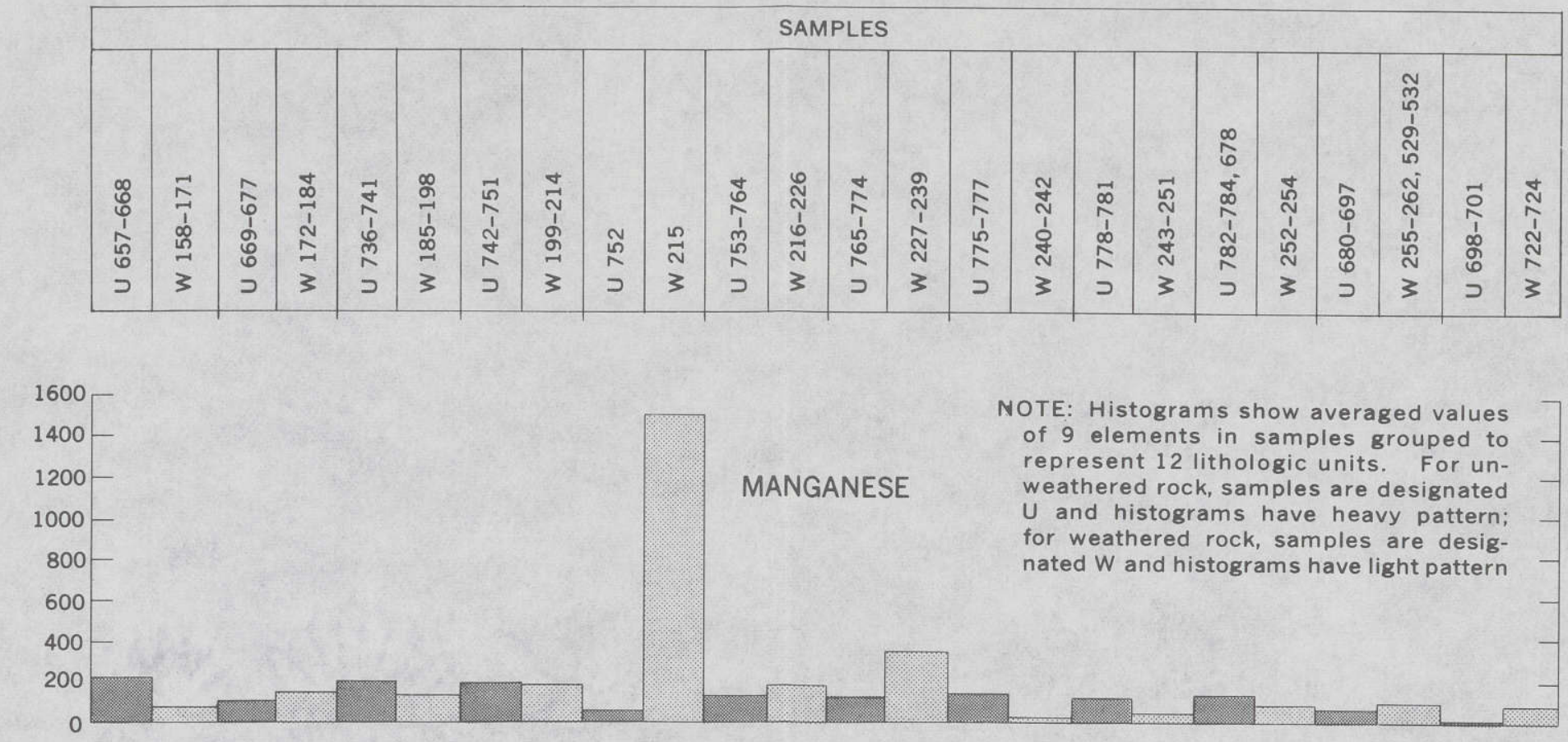

4000
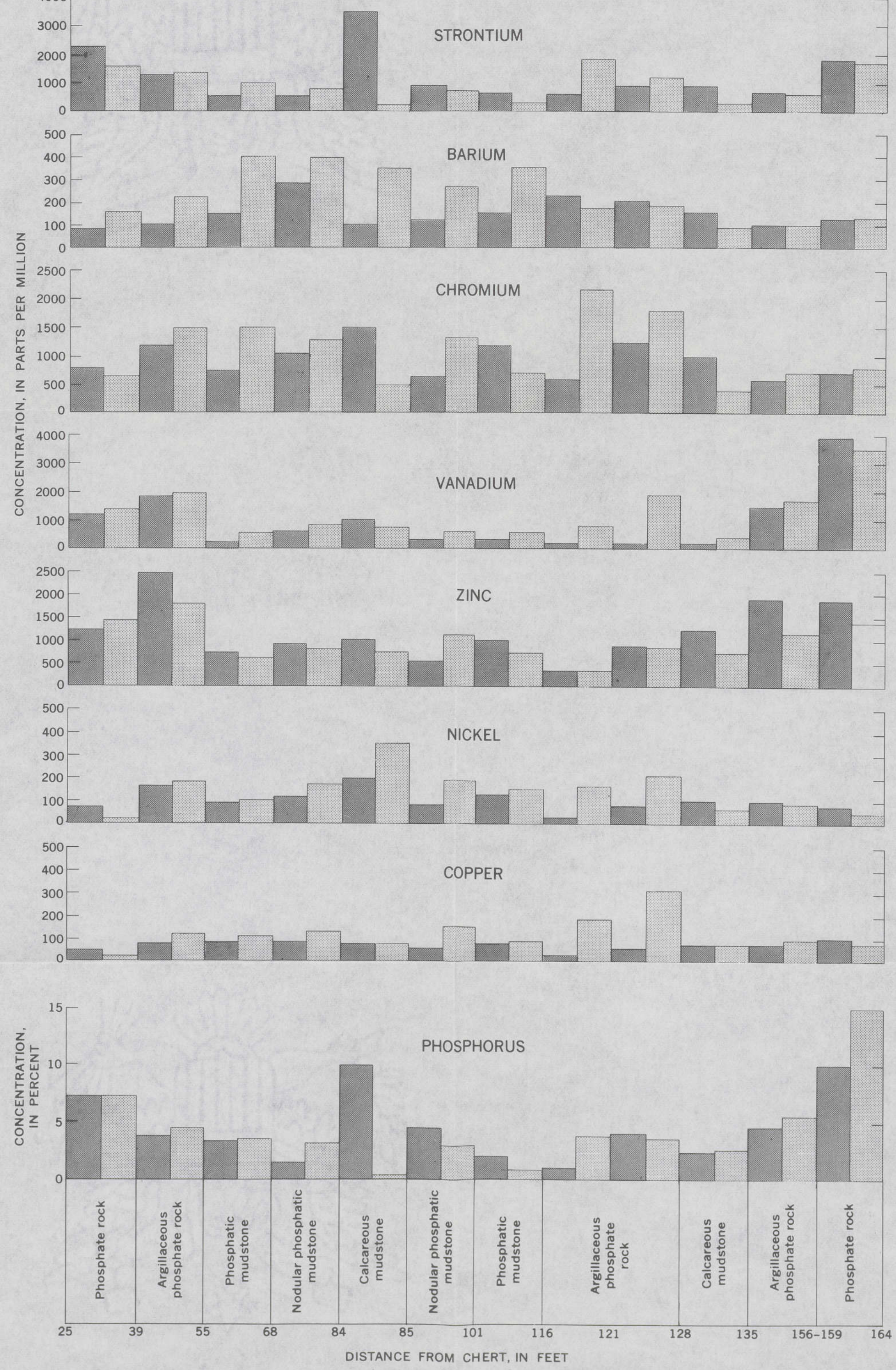

COMPARISON OF PARTIAL CHEMICAL COMPOSITION OF FRESH ROCK AND WEATHERED ROCK FROM THE MEADE PEAK PHOSPHATIC SHALE MEMBER OF THE PHOSPHORIA FORMATION NEAR GEORGETOWN IN SOUTHEASTERN IDAHO 


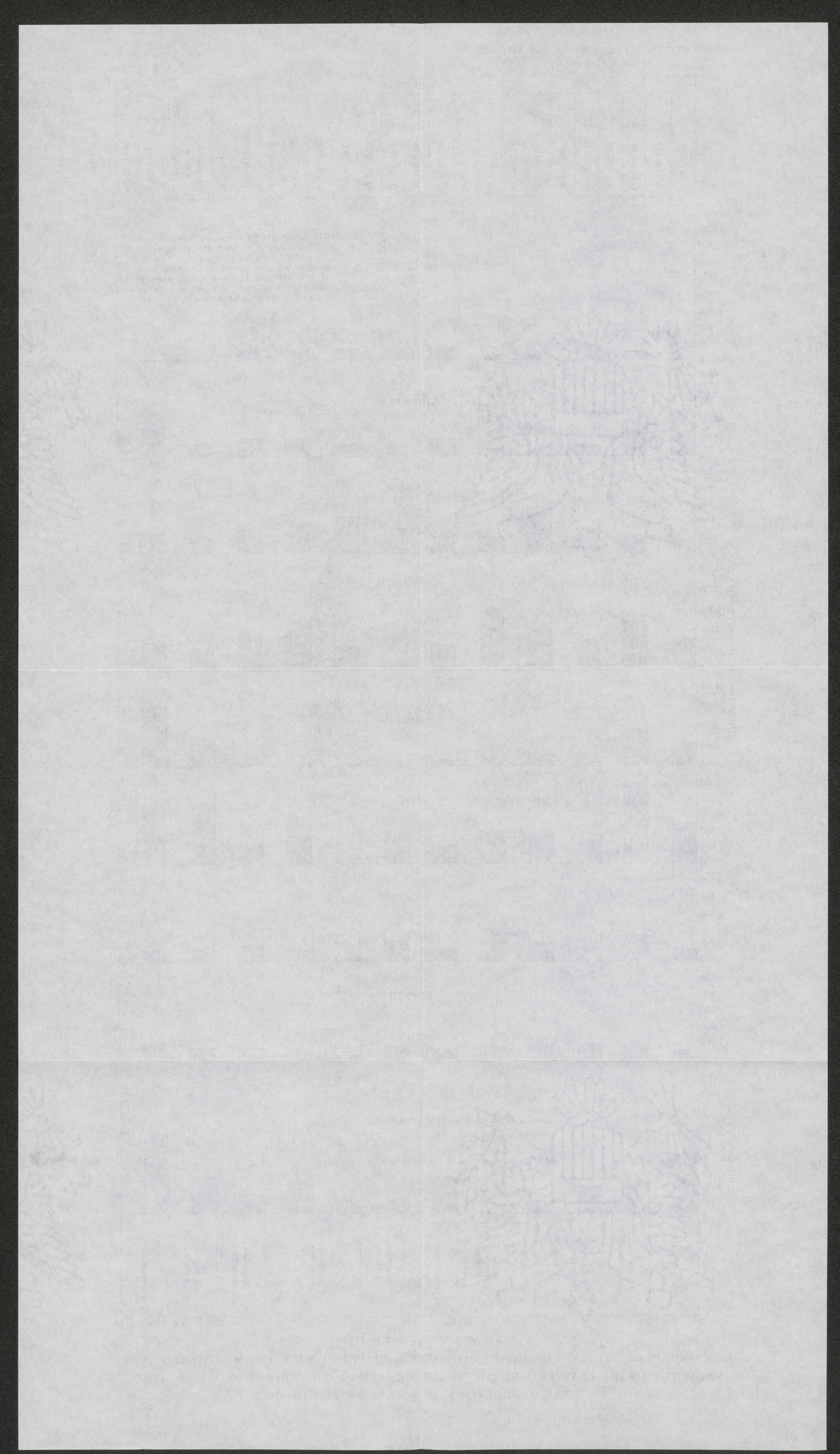

